UNIVERSIDADE DE SÃO PAULO

FACULDADE DE EDUCAÇÃO

\title{
CURSINHOS PRÉ-VESTIBULARES ALTERNATIVOS NO MUNICÍPIO DE SÃO PAULO (1991-2000): A LUTA PELA IGUALDADE NO ACESSO AO ENSINO $\underline{\text { SUPERIOR }}$
}

João Galvão Bacchetto

São Paulo

Janeiro de 2003 


\section{CURSINHOS PRÉ-VESTIBULARES ALTERNATIVOS NO MUNICÍPIO DE SÃO PAULO (1991-2000): A LUTA PELA IGUALDADE NO ACESSO AO ENSINO SUPERIOR.}

JOÃO GALVÃO BACCHETTO

Dissertação apresentada para a obtenção do grau de Mestre em Educação pela Faculdade de Educação da USP.

ORIENTADOR: PROF. DR. ROMUALDO LUIZ PORTELA DE OLIVEIRA 


\section{AGRADECIMENTOS}

- Aos meus pais, Sinesio e Anna Maria, pelo apoio e incentivo durante toda esta jornada e em tantos outros momentos.

- À minha irmã Ana Vitória, que cada vez mais se torna irmã.

- Às minhas queridas primas Ruth, Marina e Carolina, pessoas de que tenho aprendido cada vez mais a gostar.

- À Tota e ao Vicente, prima e amigo que me acolheram nos momentos importantes de descanso em Paraty.

- Aos meus amigos Natália, Eduardo, Leon, Amaral e Luciana, companheiros nos sucessos e tropeços da vida.

- Ao Celso, pessoa com que tive o prazer de conviver dentro e fora do ambiente familiar e que trouxe luz a todo este trabalho.

- À Sylvia e à Jerusa, que desde pequeno faziam festa quando me encontravam; aqui sou eu quem as quero festejar.

- À Mi e à Ziza, irmãs de criação, presentes nos mais diversos acontecimentos da vida.

- Aos amigos Jaqueline, Mirna, Lu Dadico, Fábio e Eliane, que sempre foram mais do que meros colegas de faculdade.

- À Vera, por me acolher, pelo auxílio nos momentos de grande dificuldade, e por presenciar meus progressos.

- À Sabrina, amiga da pós-graduação e companheira de tema de estudo.

- À Taís e ao Marcos, amigos da FEUSP, que me receberam de braços abertos quando estava mudando de área.

- À Sandra Zákia, com quem tive o privilégio de trabalhar conjuntamente em algumas pesquisas e de cuja sabedoria pude usufruir.

- À profa. Maria Helena de Souza Patto, cujas aulas na graduação tive o prazer de assistir, o que acabou me levando para área de educação. 
- Ao Tavares, à Pitu e à Magrela, que sempre me receberam com muita alegria quando chegava em casa.

- Ao Movimento Estudantil da USP, que me proporcionou uma vivência externa ao ambiente da Psicologia, marcando minhas escolhas posteriores.

- Aos funcionários de alguns locais da USP freqüentados por mim durante muito tempo, que me auxiliaram neste trabalho; em especial aos da Biblioteca da FEUSP, da Seção de Alunos de Pós-Graduação da FEUSP, da Seção de Alunos de Graduação do IPUSP, e à Raquel e à Solange, da Secretaria do EDA.

- Aos amigos do Serviço de Orientação Profissional do IPUSP que acompanharam meu início, com as discussões sobre o vestibular, e minha transição para a área de Educação; em especial Yvette, Conceição e Fabiano.

- Aos coordenadores de cursinhos pré-vestibulares que possibilitaram meu acesso a diversos materiais, além das entrevistas concedidas. Em especial ao Frei David, coordenador da Educafro, com quem pude ter frutíferas discussões.

- Ao Romualdo, a quem devo meu ingresso na área de Educação, que me acolheu e orientou. Agradeço pela enorme paciência, por não ralhar nas minhas ausências acadêmicas e pessoais, pela liberdade de pesquisa proporcionada, pelo bom humor e pela simpatia. 


\section{SUMÁRIO}

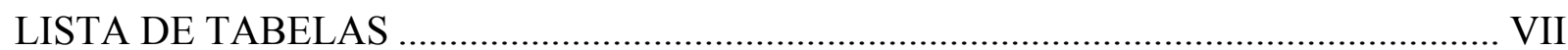

LISTA DE SIGLAS, ABREVIAÇÕES E SÍMBOLOS ..................................................... VIII

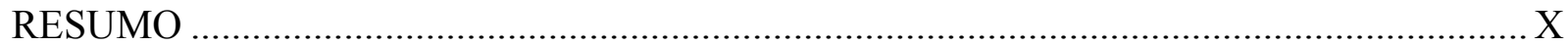

INTRODUÇÃO - Cursinhos pré-vestibulares alternativos e comerciais............................. 1

CAPÍTULO 1 - $O$ acesso ao Ensino Superior: suas características e componentes ........... 7

1.1 A reforma universitária de 1968 e alguns de seus desdobramentos................................... 8

1.2 A atual legislação educacional - implicações no acesso ao Ensino Superior .................... 19

1.3 A recente expansão do Ensino Médio ......................................................................22

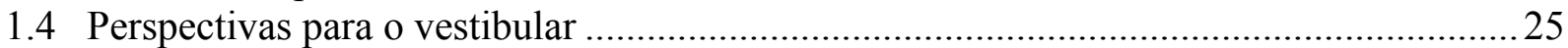

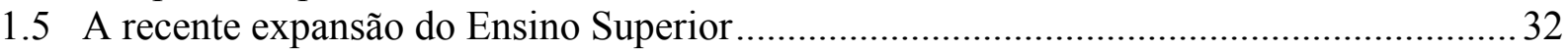

1.6 Perspectivas de reestruturação do Ensino Superior...............................................................37

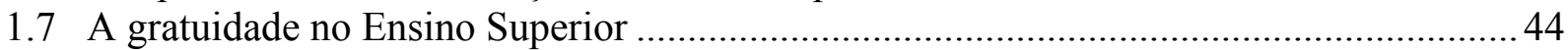

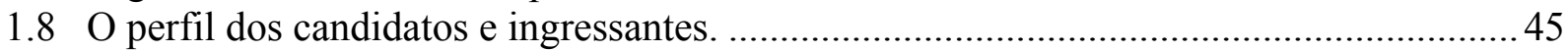

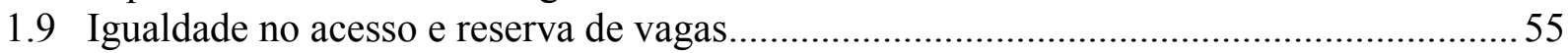

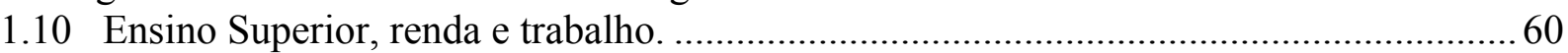

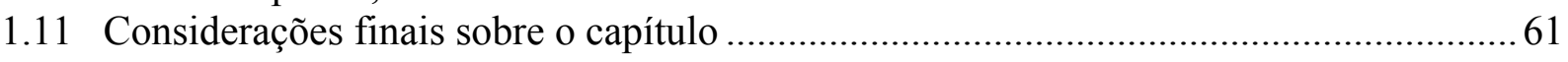

CAPÍTULO 2 - Os cursinhos alternativos no Município de São Paulo na década de 1990. 64

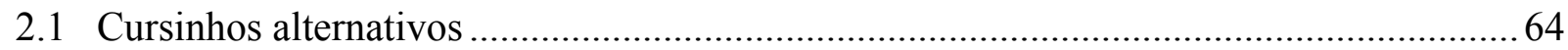

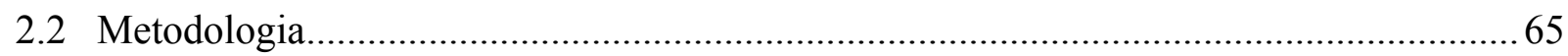

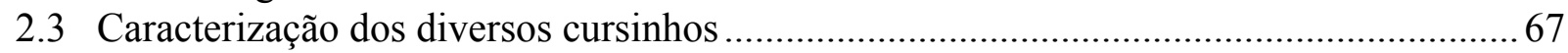

2.3.1 Educafro - Educação para Afrodescendentes e Carentes ……………………………......67

2.3.2 Grêmio da Escola Politécnica da USP - Cursinho da Poli ................................................ 71

2.3.3 APROVE - Associação de Professores para o Vestibular ................................................... 74

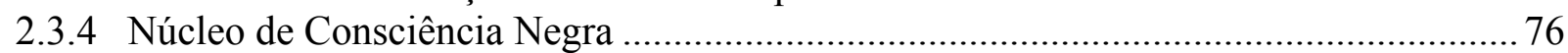

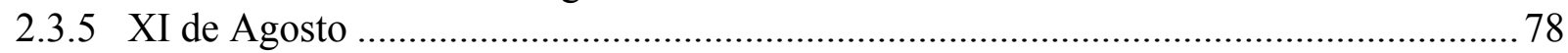

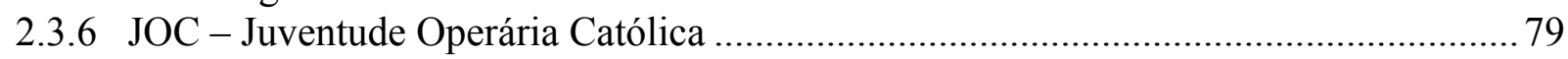

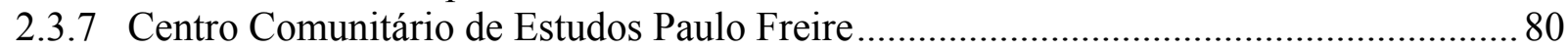

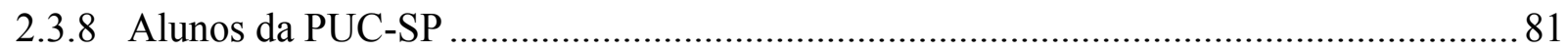

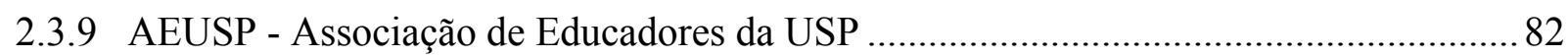

2.3.10 CAEHUSP - Centro Acadêmico de Estudos Homoeróticos................................................ 84

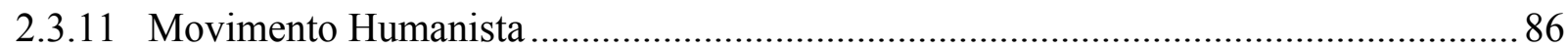

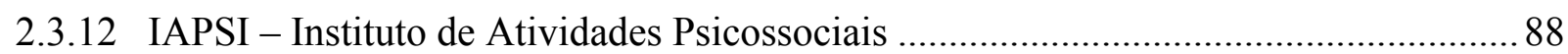

2.3.13 Thema Educação - cursinho comunitário para negros e estudantes de baixa renda ....90

2.3.14 Centro Acadêmico Visconde de Cairu ..................................................................92

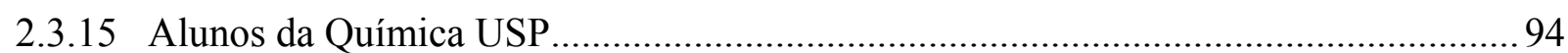

2.3.16 Clube das Mães do Brasil.......................................................................................99

2.3.17 CAIS / AFROBRAS - Sociedade Afro-Brasileira de Desenvolvimento Cultural ........97

2.4 Quadro sinóptico dos cursinhos .............................................................................. 99

2.5 Analisando algumas características dos pré-vestibulares alternativos ............................ 102

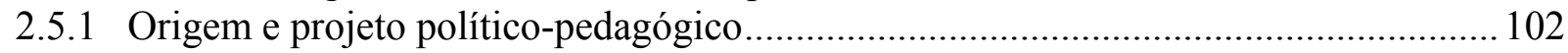

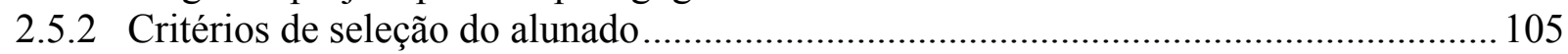

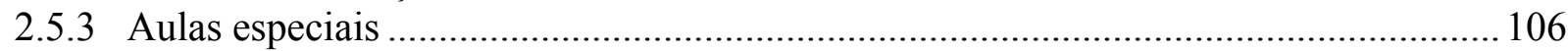

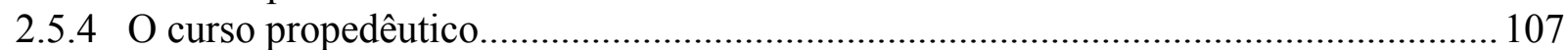

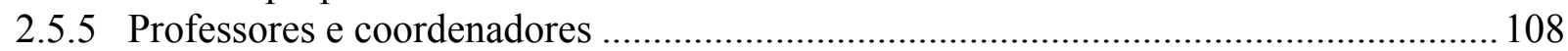




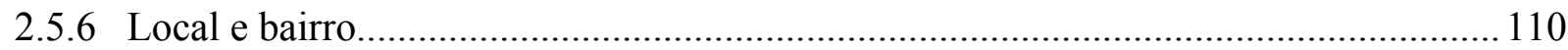

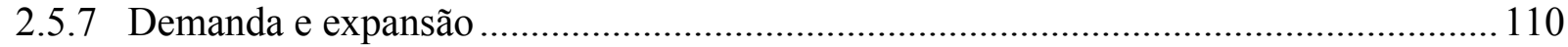

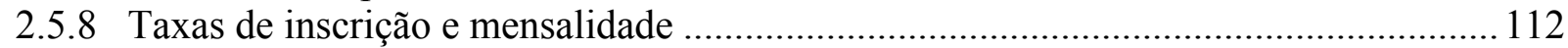

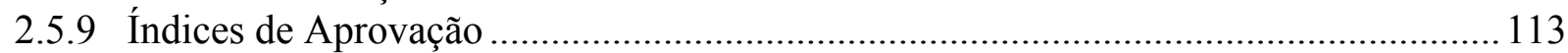

2.6 Fórum dos cursinhos alternativos e comunitários de São Paulo .................................... 114

CAPÍTULO 3 - Para além do oferecimento do cursinho: a busca pela democratização

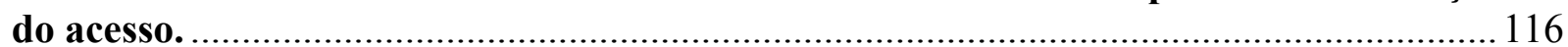

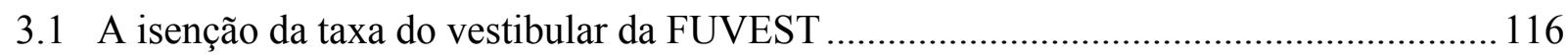

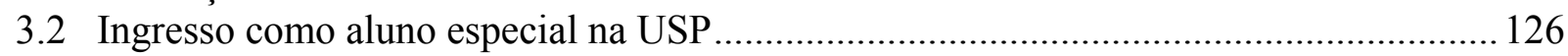

3.3 A isenção da taxa de inscrição do ENEM ................................................................. 130

3.4 Reivindicando junto ao Estado a aprendizagem dos conteúdos do vestibular ................ 133

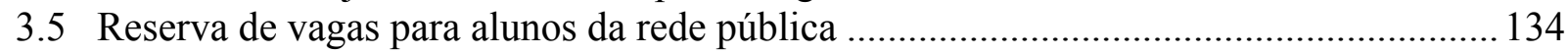

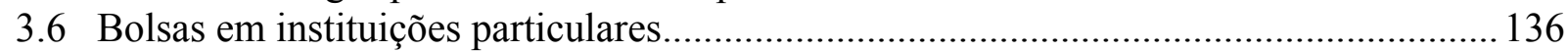

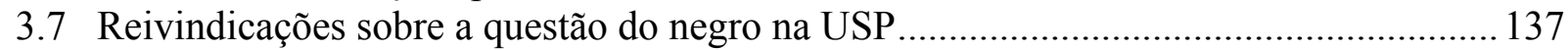

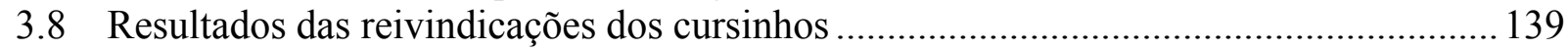

Considerações finais - Perspectivas de políticas públicas de acesso ao Ensino Superior e a participação dos cursinhos alternativos. ................................................................. 140

4.1 Isenção de taxas e redução de custos nos exames seletivos .......................................... 142

4.2 A reserva de vaga na universidade pública para estudantes oriundos do ensino público.143

4.3 Em busca da igualdade da população afrodescendente no Ensino Superior: cursinhos e

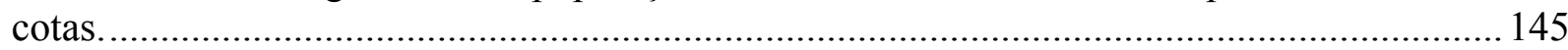

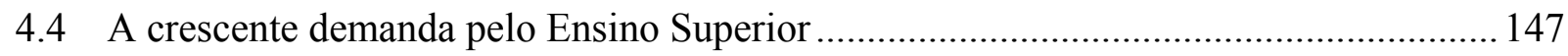

4.5 O papel dos cursinhos alternativos ..................................................................... 148

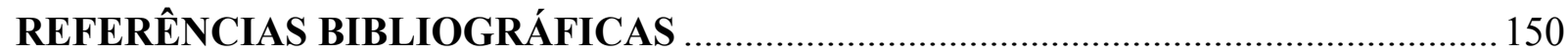

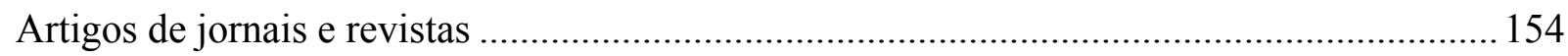

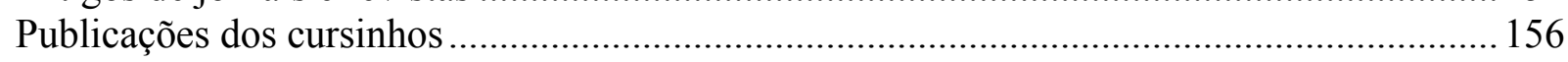

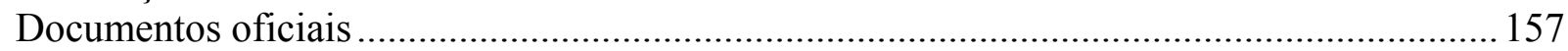

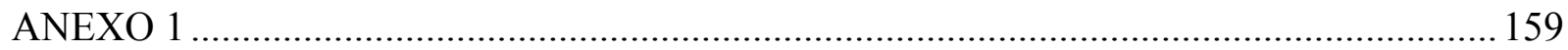

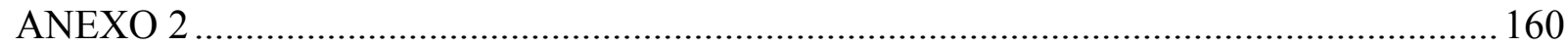




\section{LISTA DE TABELAS}

Tabela 1: Crescimento populacional e freqüência ao Ensino Médio em alguns anos.

Tabela 2: Ensino Médio - matrícula inicial por dependência administrativa de 1988 a 2001.

Tabela 3: Crescimento populacional e freqüência ao Ensino Superior em alguns anos. 32

Tabela 4: Ensino Superior - evolução da matrícula em cursos de graduação presencial por organização acadêmica 1988/2001.

Tabela 5: Ensino Superior - evolução do número de vagas no vestibular em cursos presenciais de graduação por dependência administrativa 1988/2001.

Tabela 6: Ensino superior privado por organização acadêmica, número de unidades e matrícula 1988/2001

Tabela 7: Ensino Superior - evolução do número de universidades por dependência administrativa 1988/2001.

Tabela 8: Ensino Superior - matrícula do turno noturno, segundo natureza e dependência administrativa. Brasil 1991/ 2001....

Tabela 9: Oriundos do ensino técnico federal - porcentagem destes entre o total de inscritos e matriculados em algumas carreiras do vestibular da FUVEST 2000.

Tabela 10: Grau de instrução mais alto obtido pelos pais e mães dos inscritos e matriculados segundo alternativas do questionário da FUVEST 2000.

Tabela 11: Pessoas de 10 anos ou mais de idade, ocupadas na semana de referência, por grupos de anos de estudo segundo as classes de rendimento mensal de todos os trabalhos.

Tabela 12: Núcleos da Educafro em 1999, sua localização e número de vagas. 70

Tabela 13: Número de cursinhos pré-vestibulares alternativos existentes por ano no Município de São Paulo. 


\section{LISTA DE SIGLAS, ABREVIAÇÕES E SÍMBOLOS}

ABRUC - Associação Brasileira das Universidades Comunitárias ACT - American College Testing AEUSP - Associação dos Educadores da USP

AMORCRUSP - Associação de Moradores do Conjunto Residencial da USP

APROVE - Associação de Professores para o Vestibular

CAEHUSP - Centro Acadêmico de Estudos Homoeróticos da USP

CAVC - Centro Acadêmico Visconde de Cairu

CEF - Caixa Econômica Federal

CEPE - Conselho de Ensino Pesquisa e Extensão de Serviços à Comunidade da USP

CESCEM - Centro de Seleção de Candidatos às Escolas Médicas

$\mathrm{CF}$ - Constituição Federal

CFTs - Certificados Financeiros do Tesouro

CIEE - Centro de Integração Escola Empresas

CNE - Conselho Nacional de Educação

CONVESU - Comissão Nacional de Vestibular Unificado

CREDUC - Programa de Crédito Educativo

CRUB - Conselho de Reitores das Universidades Brasileiras

CRUSP - Conjunto Residencial da USP

CRUTAC - Centro Rural Universitário de Treinamento e Ação Comunitária

DCE - Diretório Central dos Estudantes

DST - Doença Sexualmente Transmissível

EAPES - Equipe de Assessoria e Planejamento do Ensino Superior

EDUCAFRO - Educação para Afrodescendentes e Carentes

ENC - Exame Nacional de Cursos

ENEM - Exame Nacional do Ensino Médio

FEA - Faculdade de Economia, Administração e Contabilidade da USP

FEBEM - Fundação para o Bem-Estar do Menor

FFLCH - Faculdade de Filosofia, Letras e Ciências Humanas

FSP - Folha de São Paulo

FUNAP - Fundação de Amparo ao Preso

FUVEST - Fundação Universitária para o Vestibular

GED - Gratificação de Estímulo à Docência

GLTs - Gays, Lésbicas e Transgênicos

GLUSP - Gays e Lésbicas da USP

IAPSI - Instituto de Atividades Psicossociais

IBGE - Instituto Brasileiro de Geografia e Estatística

IEA - Instituto de Estudos Avançados

IES - Instituições de Ensino Superior

IFES - Instituições Federais de Ensino Superior

INEP - Instituto Nacional de Estudos Pedagógicos

INSS - Instituto Nacional de Seguridade Social

IPUSP - Instituto de Psicologia da USP 
JOC - Juventude Operária Católica

LDB - Lei de Diretrizes e Bases da Educação

MEC - Ministério da Educação

MT - Mato Grosso

NAEG - Núcleo Avançado de Estudos da Graduação da USP

NCN - Núcleo de Consciência Negra

NEAFRO - Núcleo de Estudos da Afrodescendência

OESP - O Estado de São Paulo

PAS - Programa de Avaliação Seriada

PL - Projeto de Lei

PNAD - Pesquisa Nacional por Amostra de Domicílios

PSDB - Partido da Social Democracia Brasileira

PUC-SP - Pontifícia Universidade Católica de São Paulo

PVNC - Pré-Vestibulares para Negros e Carentes

RJ - Rio de Janeiro

SABs - Sociedade Amigos de Bairro

SAPIENS - Sistema de Avaliação Progressiva para o Ingresso no Ensino Superior

SAT - Scholastic Aptitude Test

SEI - Seleção por Etapas para Ingresso

UERJ - Universidade do Estado do Rio de Janeiro

UFMG - Universidade Federal de Minas Gerais

UFSC - Universidade Federal de Santa Catarina

UNE - União Nacional dos Estudantes

UNESP - Universidade Estadual Paulista

UNICAMP - Universidade de Campinas

UNIFESP - Universidade Federal de São Paulo

USAID - United States Agency for International Development

USP - Universidade de São Paulo

VUNESP - Fundação para o Vestibular da Universidade Estadual Paulista 


\section{RESUMO}

Bacchetto, João Galvão. Cursinhos pré-vestibulares alternativos no município de São Paulo (19912000): a luta pela igualdade no acesso ao Ensino Superior. São Paulo, Feusp, 2003. (Dissertação de Mestrado)

Este trabalho aborda os cursinhos pré-vestibulares alternativos existentes no Município de São Paulo na década de 1990. Essas organizações surgiram no momento em que o Ensino Médio mais que dobrou sua matrícula, incorporando a camada social mais pobre da população. Procurando garantir o ingresso desses alunos no Ensino Superior, tais pré-vestibulares, além de oferecer o curso a preços populares, passaram a lutar por políticas de ação afirmativa que garantissem a igualdade no acesso, em especial para os alunos da rede pública e estudantes afrodescendentes. A pressão exercida já produziu alguns resultados, como a isenção de taxa em alguns exames seletivos e um maior debate sobre a desigualdade no acesso das universidades públicas. Observou-se em especial as alterações no vestibular da USP, já que esta concentra o maior número de vagas públicas daquele Município.

\section{ABSTRACT}

This dissertation takes as subject the popular preparatory courses for university entrance set in the city of São Paulo in the decade of 1990. Such organisations were established when middle and high school education started to embody a larger number of people coming from the lower income population. During this period school enrolment increased to more than twice the rate observed in the previous period. Aiming to assure students of lower income could access higher education, popular preparatory courses, besides charging lower prices for their services, began to claim for affirmative action policies. Such policies should provide social equality regarding public universities' accessibility, especially to students coming from public schools and afro-descents. Political pressure as engendered by that movement has already achieved some results, such as exemption of inscription fees for some entrance examination and a more intensive social debate on the present inequality concerning access to public universities. Changes occurred in the entrance examination for the University of São Paulo (USP) deserve special remark, since this institution concentrates the highest number of public vacancies within the above-mentioned city.

Unitermos: cursinho, vestibular, Ensino Superior, igualdade, direito à educação, política educacional, reserva de vagas, ação afirmativa, ENEM.

Linha de Pesquisa: Estado, Sociedade e Educação

Banca Examinadora: Orientador: Prof. Dr. Romualdo Luiz Portela de Oliveira

Prof. Dr. Afrânio Mendes Catani

Prof. Dr. Fernando Dagnoni Prado

\section{Data da defesa:}

João Galvão Bacchetto (1970) é paulistano, psicólogo formado pelo Instituto de Psicologia da USP em 1995, com especialização em Orientação Profissional pelo Serviço de Orientação Profissional do IPUSP. Atuou como representante discente em diversos órgãos colegiados da USP, dentre eles o Conselho Universitário, o Conselho de Graduação e o Conselho de Pós-Graduação. Realizou pesquisas junto ao Centro de Estudos e Pesquisas de Políticas Públicas da Educação da Feusp. Email: jogalvao@hotmail.com. Telefone: (11) 98027985. 


\section{INTRODUÇÃO - Cursinhos ${ }^{1}$ pré-vestibulares alternativos e comerciais}

O Ensino Médio brasileiro mais que dobrou suas matrículas durante a década de 1990, passando a atender uma nova parcela da população, antes excluída. Com a generalização desse certificado, muitos passaram a procurar o diploma superior, que adquiriu um diferencial para a conquista de emprego, mesmo que não relacionado com a área específica da graduação.

Para atingir o Ensino Superior, alguns obstáculos se apresentam para essa população. Por pertencerem a um estrato mais pobre da população, muitos não conseguem arcar com os custos de um pré-vestibular e muito menos com os de uma universidade particular.

No bojo dessa situação surgiram os cursinhos alternativos. Baseados no princípio da igualdade, eles procuram nivelar as oportunidades do estudante de menor renda com as daquele formado em uma escola média de melhor nível, e que pode pagar um cursinho comercial ${ }^{2}$, passando a oferecer o mesmo serviço a preços populares e com a expectativa de ingresso numa universidade pública. Esses novos pré-vestibulares proliferaram por vários estados e municípios do Brasil, e este trabalho irá abordar somente aqueles que funcionaram no município de São Paulo, no período de 1991 a 2000.

Os cursinhos consistem em organizações específicas de treinamento para o exame de acesso ao Ensino Superior, uma das modalidades de estudo possíveis, como nos relata Anísio Teixeira:

O aluno aprovado [no Ensino Médio] que se candidata ao vestibular, estuda, por sua conta, para exame, ou tomando o professor particular, ou estudando por si, ou matriculando-se em alguns dos cursinhos que são de treinamento especial para o exame. (Teixeira, 8 maio 1968, p.146)

A grande expansão dos cursinhos parece ter ocorrido nas décadas de 1960/70, mas não se encontrou nenhum estudo sobre o tema, o que constitui uma lacuna na

\footnotetext{
${ }^{1}$ Para designar os cursos preparatórios para o vestibular utilizou-se os termos cursinho, pré-vestibular ou, simplesmente, preparatórios.

${ }^{2}$ Denominação adotada para os cursinhos com fins lucrativos.
} 
pesquisa educacional, já que alguns serviram de alavanca para grandes empresas educacionais: tornaram-se universidades, franquias de escolas de ensino médio particular e/ou fornecedores de material educacional ${ }^{3}$ para esse nível.

Para Sérgio Costa Ribeiro, em A visão de professores e alunos das IES hoje, o surgimento dos cursos pré-vestibulares está associado ao crescente número de candidatos ao Ensino Superior e ao aumento de dificuldade das provas:

Os exames vestibulares passaram a exigir conhecimentos cada vez mais específicos, transferindo-se muitas vezes conteúdos próprios do Ensino Superior para o curso secundário. Estas distorções tiveram efeitos desastrosos, tanto para a escola secundária, como para o Ensino Superior.

A escola secundária, incapaz de especializar-se ao nível dos inúmeros exames vestibulares existentes, repassa aos chamados cursos preparatórios (cursinhos) a responsabilidade de treinar os candidatos aos vestibulares. A partir do $2^{\circ}$ ano do então colegial, os alunos eram transferidos para os "cursinhos"; estes, por sua vez, à margem do sistema formal, se permitiam toda a sorte de abusos, com turmas gigantescas, por exemplo. (Ribeiro, 1987, p.30)

Para Renan Springer de Freitas, autor de um estudo sobre os cursinhos, a ausência de pesquisas sobre o tema deve-se a vários motivos: eles não pertencem ao sistema oficial de ensino e não são objeto de políticas por parte do Estado; não oferecem 'certificados' aos seus concluintes; não são ponto terminal de nenhuma etapa educacional, e sim de preparação para outra; não credenciam ao mercado de trabalho e não têm qualquer fiscalização ou controle por parte do Estado. Para este autor, embora não façam parte da rede oficial, eles constituem um nível do sistema educacional, opcional ou compulsório, mas já institucionalizado (Freitas, 1984).

Referências sobre os cursinhos são normalmente encontradas em trabalhos que exploram o ingresso no Ensino Superior ou as conseqüências do vestibular sobre o Ensino Médio.

Célia L. M. de Castro, em Caracterização sócio-econômica do estudante universitário, procura delinear um perfil dos calouros de 1965 e mostra que $65,71 \%$ deles chegaram a cursar pré-vestibulares. Num grande centro urbano como São Paulo, esse índice subia para 75,80\%, e, no concorrido curso de Medicina da USP, este

\footnotetext{
${ }^{3}$ Um fenômeno perceptível é a adoção das apostilas inicialmente confeccionadas com a finalidade de preparação para o vestibular em substituição aos livros didáticos no ensino médio particular.
} 
percentual chegou a 94,44\%. Muitos ainda declararam ter realizado dois anos de cursinho antes do sucesso no vestibular. (Castro, 1968, p.33-228:234)

A associação entre o sucesso no vestibular e o curso preparatório permanece. No exame de 2000 da FUVEST, 60,9\% dos inscritos haviam feito pré-vestibular; no total dos matriculados, esse percentual sobe para $68,4 \%$. Na carreira de medicina ${ }^{4}$ esses estudantes representaram $69,3 \%$ dos inscritos e $84,6 \%$ dos matriculados, e, dentre os que obtiveram sucesso, um total de $48,0 \%$ declarou ter realizado mais de um ano de cursinho.

Dulce C. A. Whitaker chegou a constatar um "efeito cursinho" nos vestibulares da UNESP de 1985 e 1986. Nos cursos de grande concorrência, a maior probabilidade de aprovação pertencia àqueles já formados há um ou dois anos - podendo se supor que esse tempo foi dedicado a um estudo especializado. Confirmando este efeito, os estudantes que declararam ter feito de um a dois anos de pré-vestibular possuíam maiores índices de ingresso, o que se deu principalmente nas carreiras que exigiram melhor preparo. "Há relação direta quase mecânica entre prestígio do curso e porcentagens de candidatos privilegiados pelo treinamento de cursinhos". (Whitaker, 1989, p.24)

Dez anos depois, observando os vestibulares da Unesp de 1995 e 1996, Whitaker e Elis Cristina Fiamengue constataram que houve diminuição do número de candidatos que realizaram cursinhos, revelando a existência de novas modalidades de estudo para o vestibular. Entretanto, acentuou-se o "efeito cursinho", com "quedas vertiginosas" nos índices de aprovação dos sem cursinho. (Whitaker \& Fiamengue; 1999)

Ernst Hamburguer, em $O$ exame vestibular e os desajustes do sistema de ensino, atesta a importância dos cursinhos para o ingresso, e o caráter sócio-econômico que impõem à seleção já em 1970:

O primeiro fato que devemos salientar aqui é que a esmagadora maioria dos alunos aprovados passou por cursinho. Pelos anúncios nos jornais vemos que em certas escolas mais procuradas $97 \%$ dos candidatos aprovados são de um só

\footnotetext{
${ }^{4}$ A carreira de medicina na Fuvest no ano de 2000 comportava os cursos da USP (São Paulo e Ribeirão Preto), UNIFESP e da Faculdade de Ciências Médicas da Santa Casa; este último cobra mensalidades de seus estudantes.
} 
cursinho! Em outras escolas vários cursinhos dividem entre si as vagas. Obviamente há muitos candidatos que fazem cursinho e não entram; mas são pouquíssimos os que entram sem cursinho. A primeira e grande seleção é portanto sócio-econômica - só pode entrar na universidade quem tem condições de pagar e seguir um cursinho. (Hamburguer, 1970, p.13)

Para que não ocorresse uma seleção sócio-econômica seria necessária a existência de uma rede de cursinhos públicos e gratuitos, o que, no Brasil, inexiste. Encontrou-se somente a experiência patrocinada pelo Governo do Estado do Pará, que manteve o "convênio vestibular" - com o oferecimento de cursinho - em 21 escolas de nível médio no ano de 1995. Essa pode ser considerada a exceção que confirma a regra. (Pará, 1995, p.20)

A inexistência de uma rede de cursinhos na qual o estudante de baixa renda possa se preparar para o vestibular acaba constituindo um fator de desigualdade no exame, e é no combate a ela que surgem os cursos alternativos aqui estudados. Diferentes dos pré-vestibulares mais conhecidos, os de cunho comercial - empresas educacionais que visam à obtenção do lucro através da prestação desse serviço aos vestibulandos -, os alternativos procuram oferecer igualdade de condições no ingresso ao Ensino Superior para aqueles com menor poder aquisitivo; caracterizam-se pela ausência do lucro e pela oferta desse serviço a preços populares.

A compreensão do que seria atingir a igualdade no acesso ao Ensino Superior não se restringiu ao nivelamento das condições de estudo; alguns cursinhos alternativos procuraram garantir que seus alunos, de baixo nível sócio-econômico, tivessem o mesmo direito de freqüentar as boas universidades públicas que outros, com melhores condições. A partir disso, criaram diversas propostas para superar os obstáculos detectados no caminho rumo à igualdade.

Uma dessas propostas é a isenção da taxa de inscrição nos vestibulares, valor que seria um impedimento para estudantes sem condições financeiras. A proposta da gratuidade foi também levada para a inscrição do ENEM - Exame Nacional do Ensino Médio, uma vez que este passou a integrar o sistema seletivo de diversas universidades.

Alguns cursinhos também defenderam a reserva de vagas para estudantes portadores de algumas características que sempre eram desfavorecidos na seleção. Duas se destacaram por ter sido aprovadas em algumas instâncias legislativas: a que 
reserva uma parcela das vagas para estudantes que cursaram escola pública, e outra, para estudantes afrodescendentes.

A importância do estudo dos pré-vestibulares alternativos transcende as inovações que porventura tenham realizado para acolher e garantir o treinamento voltado ao exame seletivo dos alunos com menor renda, mas inclui também as propostas de alteração nos processos seletivos, sua eficácia, os motivos e as concepções que as embasam, as modificações implementadas e seus resultados.

Para conhecer este novo universo, escolheram-se alguns tópicos considerados importantes para a compreensão desses cursinhos:

a) suas características;

b) suas propostas e motivações;

c) as organizações patrocinadoras dessa atividade;

d) as transformações causadas no acesso ao Ensino Superior.

Traçou-se também um quadro teórico com os vários elementos que historicamente e atualmente influenciam no acesso ao Ensino Superior, com a discussão de aspectos relacionados ao Ensino Médio, aos mecanismos que regulam a seleção universitária e às políticas de expansão e atendimento da demanda no nível superior.

As visitas aos alternativos ocorreram entre 1999 e 2002 e compreenderam os cursinhos que funcionaram no município de São Paulo na década de 1990. Nos que já haviam encerrado suas atividades, entrevistaram-se os antigos organizadores. Além de entrevistas, houve coleta de todo tipo de material impresso relacionado direta ou indiretamente às suas atividades.

Dentro do rótulo de "alternativo" foi verificada grande diversidade. Origens semelhantes não se desdobraram em propostas políticas e formas organizacionais também semelhantes; assim, procurou-se apenas assinalar as características comuns, sem que isto implicasse num duvidoso processo classificatório. Em comum houve apenas a proposta de atender alunos com baixo nível sócio-econômico.

Observaram-se também as diversas transformações ocorridas nos exames vestibulares das universidades públicas e as possíveis correlações disso com a atuação dos alternativos, e foi dedicada particular atenção às alterações relacionadas à 
FUVEST, por oferecer o maior número de vagas públicas no município em que se concentra a amostra.

Tais cursinhos apresentaram uma meta bastante ambiciosa, pois a desigualdade sócio-econômica é patente em alguns cursos e carreiras e, historicamente, a maioria da população financeiramente desfavorecida nunca chegou próxima a esse nível de ensino. As concepções que embasaram suas atuações, os caminhos encontrados para encarar este desafio e algumas possíveis conseqüências são relatadas neste trabalho.

No primeiro capítulo foi realizada uma retrospectiva das mudanças educacionais advindas da reforma universitária de 1968, bem como as motivações que a antecederam. Foram também observadas as alterações no período posterior a promulgação da Constituição Federal de 1988, com ênfase no crescimento dos Ensinos Médio e Superior no período, e as alterações no sistema vestibular. Foram encontrados alguns pontos em comum na política educacional dessas duas épocas.

Já no segundo capítulo, observou-se a criação dos cursinhos pré-vestibulares alternativos como conseqüência de um aumento da demanda pelo Ensino Superior, ocasionado por uma nova camada populacional que passou a ser atendida pelo Ensino Médio. Foram também descritas e analisadas as características de cada cursinho encontrado.

No terceiro capítulo, documentou-se diversas manifestações dos cursinhos alternativos que visaram à alteração do vestibular de forma a facilitar ou garantir o ingresso desses alunos com menor condição sócio-econômica. A ação dos cursinhos provocou algumas alterações no vestibular da FUVEST durante a década de 1990.

Por último, foram tecidas algumas considerações sobre o papel dos cursinhos, sobre o problema da desigualdade no acesso, e perspectivas de políticas públicas para atender a crescente demanda pelo Ensino Superior. 


\section{CAPÍTULO 1 - O acesso ao Ensino Superior: suas características e componentes}

Este capítulo reúne alguns dos principais fatores que determinam e influenciam o acesso ao Ensino Superior, suas principais características e mudanças em pauta. Para compreender esse quadro, e as ocorrências do passado que o determinaram, utilizou-se como referência básica o texto Educação e sociedade no Brasil após 1930, de Celso Beisiegel (1986).

No referido texto, o autor observa, em linhas gerais, que a democratização do ensino comum aos cidadãos se deu através de dois principais fatores, a expansão da matrícula, como conseqüência da pressão popular, e o fim dos diferentes tipos de Ensino Médio, como uma adaptação que o sistema teve de realizar para abrigar maior contingente populacional.

Além da expansão do ensino regular, Beisiegel registrou várias ações que procuraram resolver os problemas educacionais presentes, como programas específicos para atender aqueles que não puderam escolarizar-se na idade esperada; políticas de merenda escolar; classes de recuperação; adoção do ensino noturno; incentivo ao atendimento do pré-escolar etc.

Essa democratização, todavia, não ocorreu uniformemente, e alguns grupos não tiveram acesso às possibilidades abertas, continuando à margem do sistema educacional.

Beisiegel relata que, com a expansão do sistema, as barreiras seletivas da educação foram sendo, pouco a pouco, empurradas para os graus mais elevados.

Não é, senão isso, o que novamente se presencia; a expansão do sistema de ensino continua a ocorrer nos diversos níveis. Neste estudo enfatiza-se o crescimento do nível médio e a pressão pelo acesso ao superior na década de 1990. A compreensão deste fenômeno será fundamental para o entendimento das propriedades que assumem o acesso ao Ensino Superior, tema central deste primeiro capítulo.

A reforma universitária de 1968 foi eleita como ponto inicial de análise por ser nela, e no período subseqüente, que se encontra boa parte das formulações que ainda 
hoje são referência para a expansão do sistema de Ensino Superior, e que influenciaram suas atuais características.

Não são detalhadas todas as transformações ocorridas nos diversos níveis de ensino da época, mas aquelas pertinentes à discussão sobre a admissão na etapa mais elevada da escolarização.

\subsection{A reforma universitária de 1968 e alguns de seus desdobramentos}

Luiz Antônio Cunha, em A universidade crítica (1989), relata que boa parte da reforma universitária de 1968 teve como motivação alterações estruturais ocorridas no período anterior. Assim, após o Estado Novo, a educação escolar adquiriu novo significado:

Ficando mais difícil acumular o capital necessário ao ingresso nas classes dominantes, passou-se a definir o topo das burocracias públicas e privadas como o alvo da ascensão. Buscava-se a promoção no interior das burocracias resultantes (as privadas) e as propiciadoras (as públicas) do próprio processo de monopolização que inviabilizou o processo empresarial de ascensão. Como essas burocracias são organizadas de forma hierárquica, utilizando os graus escolares como requisitos de admissão e promoção aos diversos níveis de poder, remuneração e prestígio, houve uma demanda aumentada numa proporção superior à dos outros graus. (Cunha, 1989, p.48)

Essa mudança impulsionou as camadas médias urbanas à procura incessante pelos títulos do Ensino Médio e, posteriormente, do Ensino Superior; a pressão popular gerou grande expansão do ensino nesses dois níveis, fenômeno melhor observado no Estado de São Paulo, que já possuía uma rede de ensino primário consistente.

Celso Beisiegel, em Ação política e expansão da rede escolar (1964), mostra que, após a Constituição Paulista de 1947, a abertura de novos ginásios ficou sob a responsabilidade da Assembléia Legislativa. Os deputados, sensíveis à pressão popular, viam na abertura de escolas de nível médio uma boa forma de amealhar votos em suas regiões. 
De acordo com Beisiegel, em 1940 existiam 41 ginásios no Estado de São Paulo. Já em 1962 esse número disparou para 561, tornando-se quase consenso a necessidade de um ginásio em cada cidade paulista. Esse aumento não foi realizado de forma planejada, mas principalmente determinado pelo comportamento da Assembléia Legislativa e interesses de seus integrantes.

Entretanto, no final do período estudado, o Ensino Médio ainda era oferecido predominantemente pela iniciativa particular. O crescimento da matrícula no setor público concentrou-se nos cursos secundários, que até 1961 eram os únicos a permitir a inscrição em qualquer carreira no Ensino Superior.

Para aumentar a capacidade de atendimento ao alunado, Beisiegel presenciou o emprego de recursos como: oficialização do magistério leigo, regime de quatro turnos, redução da carga horária do aluno na escola, criação de classes de emergência, instalação de escolas em prédios inadequados, dentre outros.

Essa expansão deu-se de maneira diferenciada na capital e no interior, sendo que na primeira o crescimento da matrícula no Ensino Médio ocorreu mais pela abertura de seções escolares e oferecimento de ensino noturno, e na segunda, pela abertura de novas unidades escolares por ação dos deputados estaduais.

A regulamentação do ensino noturno na capital ocorreu em 1947 em dois ginásios e já nos anos seguintes vários outros passaram a oferecer o curso nesse período. Tal processo foi estudado por Marília Pontes Spósito em $O$ povo vai à escola. Ela relata que o funcionamento do noturno, no início, era precário, sem iluminação e higiene adequadas.

Para não ficar na dependência da Assembléia Legislativa, o então chefe do governo estadual, Jânio Quadros, utilizou-se do recurso de abrir seções dos colégios já existentes em bairros desprovidos de ginásio. Com o tempo estas foram se tornando independentes e ganharam autonomia administrativa, concedida, posteriormente, pela Assembléia Legislativa.

As reivindicações pela escolarização partiram, segundo Spósito, das Sociedades Amigos de Bairro - SABs, que haviam se formado a partir da população que imigrava para os bairros periféricos de São Paulo. Nesses locais lutava-se por condições básicas de moradia, como água, luz e esgoto. Apesar de a educação escolar ser um projeto a longo prazo, ele não era menos urgente para os moradores dos recém criados bairros, 
que se cotizavam para pagar professores que alfabetizassem seus filhos. Com a presença de Jânio no Poder Executivo Paulista e o atendimento das primeiras demandas por unidades escolares, novas solicitações foram sendo encaminhadas, cada vez em maior número.

Com o grande aumento da escolarização decorrente da ampliação das oportunidades educacionais, Spósito conclui:

Uma vez transformada, por meio de acessos de setores mais amplos da população, a escola secundária deixou de ser privilégio de poucos e, agora, como patrimônio de grande parte da sociedade, poucas vantagens propicia para alterar, de modo mais significativo, a situação social das camadas populares. (Spósito, 1984, p.20)

Beisiegel refere-se à situação paulista da seguinte forma:

As diversas barreiras seletivas vêm sendo pouco a pouco empurradas para os degraus mais elevados da pirâmide escolar - do primário para o primeiro ciclo do nível médio e deste para os cursos médios de segundo ciclo e para o Ensino Superior. (Beisiegel, 1986, p.389)

Assim, o projeto de ascensão social pela educação transferiu-se para o diploma superior, de público muito restrito, mas isso forçou outras alterações ainda no nível anterior.

A reforma educacional de 1942 estruturava o Ensino Médio em dois ciclos: o ginasial de quatro anos, e um segundo, composto por dois cursos paralelos - o clássico e o científico -, sendo que, mediante a prestação de exames de saída, permitia-se a progressão nos estudos. As normas dos exames de habilitação para o Ensino Superior eram regulamentadas pela então Diretoria de Ensino Superior do Ministério da Educação e Saúde.

Com o aumento da procura pelo diploma superior, várias medidas visaram facilitar o ingresso na universidade. Em especial destacam-se as "leis de equivalência", que permitiram a matrícula nos cursos clássico e científico a estudantes provenientes de outros cursos ginasiais, como industrial, agrícola, comercial, normal, além de permitir que concluintes de cursos técnicos profissionalizantes prestassem exame para alguns cursos superiores. 
A Lei de Diretrizes e Bases da Educação n ${ }^{\circ} 4.024$ de 1961 (LDB) deu o golpe final no sistema anterior. Em seu artigo 34 definiu que o ciclo colegial do Ensino Médio abrangeria os cursos secundários, técnicos (industrial, comercial e agrícola) e de formação de professores para o ensino primário e pré-primário. Incorporando os cursos profissionalizantes e igualando todos os diplomas neste nível, aumentou sensivelmente o contingente de pessoas aptas a seguir nos estudos superiores.

Segundo Luiz Antônio Cunha:

Trincada a estrutura dual no Ensino Médio, pelas "leis de equivalência" e pela LDB, os exames vestibulares passaram a ser a grande visível muralha a obstruir a caminhada das camadas médias em busca dos diplomas superiores, requisito de ascensão ocupacional/social. O movimento de facilitação do ingresso no Ensino Superior voltou-se então para a atenuação dessa barreira, visando até mesmo sua supressão. (Cunha, 1989, p.84)

A luta pelo ensino superior público deu-se em várias frentes, tendo como alguns resultados a federalização de escolas municipais e/ou particulares. É dessa época também o fim da cobrança de taxas escolares nos estabelecimentos oficiais, antiga reivindicação do movimento estudantil e de outros setores da sociedade brasileira. $\mathrm{O}$ fim das taxas se deu pela corrosão da inflação sobre os valores e por um contexto político que não favorecia reajustes.

Algumas reformas no vestibular também começaram a ser realizadas. $\mathrm{O}$ exame classificatório foi adotado ainda em 1963/64 na Faculdade Nacional de Filosofia. Por esse sistema, não haveria vagas ociosas por insuficiência de conhecimento dos candidatos; todas as cadeiras oferecidas teriam de ser preenchidas. No outro sistema, $o$ eliminatório, a exigência de conhecimentos mínimos gerava ociosidade, fato incompatível com a grande pressão pelo ingresso.

O problema dos "excedentes" já era visível desde 1950. Eram estudantes aprovados no exame, com nota superior a cinco, e aptos a se matricular, mas sem a classificação adequada, ficando abaixo do número de vagas oferecidas 5 . Muitos acabaram por conquistar o direito ao ingresso através de decisões judiciais favoráveis.

\footnotetext{
${ }^{5}$ A política de numerus clausus que limitava o número de vagas vigorava desde a década de 1920; de acordo com ela, o número de ingressantes seria restrito às vagas oferecidas.
} 
As escolas passaram a receber novos alunos sem possuir as condições estruturais adequadas. Esse processo intensificou-se na década de 1960.

A demanda por maior escolaridade incrementava-se com o passar dos anos; as organizações estudantis abraçavam a causa, pautando a extinção do vestibular em congressos da UNE, maiores verbas para as universidades e diversas reformas educacionais. Mesmo após quatro anos de governo militar, o movimento estudantil ainda erguia bandeiras de protesto em praças públicas.

O governo militar só conseguiu implantar seu projeto para as universidades quase cinco anos após a tomada do poder; durante esse tempo, procurou abafar os "movimentos subversivos" que rodeavam a vida universitária. Ações foram desenvolvidas em várias frentes, como a destituição de dirigentes universitários simpatizantes do regime anterior; abertura de inquéritos para averiguar a participação de professores em atos subversivos, com a demissão de vários; procura pela regulamentação e disciplinamento do Movimento Estudantil (Lei Suplicy de Lacerda $\left.n^{\circ} 4.464 / 64\right)$; e a tentativa de inserção do aluno no mercado de trabalho, com a criação do Centro de Integração Escola Empresas - CIEE - e do Centro Rural Universitário de Treinamento e Ação Comunitária - CRUTAC ${ }^{6}$.

Com o acirramento da crise estudantil, passou-se das recomendações para as intervenções. Foi instituída, em 1966, a Comissão Especial para Assuntos Estudantis ${ }^{7}$, que produziu um relatório recomendando poderes ao Presidente para intervir diretamente na mudança de diretores e reitores que não respeitassem o princípio de autoridade. O relatório propunha ainda três medidas para a resolução dos problemas vinculados ao Ensino Superior: reestruturação racional do MEC e órgãos administrativos vinculados a ele; diminuição da ociosidade do corpo docente e dos espaços universitários, com a adoção do regime de créditos; e contenção de abuso nas taxas por parte das instituições de ensino médio particulares e dos cursinhos, com a expansão do Ensino Superior através da cobrança de mensalidades e o direcionamento de novos investimentos e fontes de crédito para o setor. (Cunha, 1988, p.91:104)

\footnotetext{
${ }^{6}$ Os projetos que visavam a aproximação dos estudantes com o mundo do trabalho tinham por objetivo afastá-los do movimento estudantil. Muitas vezes a inscrição só era permitida caso o aluno assinasse um termo no qual afirmava não estar envolvido em ações políticas. (Cunha, 1988, p.70)

${ }^{7}$ Conhecida também, devido ao nome de seu presidente, como Comissão do General Meira Mattos.
} 
Foi nessa época, também, que o MEC firmou o convênio de cooperação técnica com a USAID ${ }^{8}$, que foi efetivado através da Equipe de Assessoria e Planejamento do Ensino Superior - EAPES -, que iniciou suas atividades em 1965 e só veio a concluir seu relatório em 1969.

$\mathrm{O}$ acordo MEC-USAID tornou-se o alvo principal dos estudantes que explicitavam sua opção por um projeto no qual a universidade estivesse engajada na transformação social, contrapondo-se ao projeto do governo militar, cujo objetivo era voltar o Ensino Superior à formação de recursos humanos como forma de acelerar o desenvolvimento econômico do país.

A EAPES sofreu muitas resistências para sua instalação, só conseguindo em 1967 receber número de pesquisadores brasileiros suficiente para sua composição, após a recusa de muitos. Essas recusas aconteceram por diversos motivos, mas o principal constituiu-se num boicote do Conselho Federal de Educação, que, como órgão responsável por respaldar as indicações, não tinha interesse em dividir a responsabilidade de planejamento e direção do destino do Ensino Superior com uma organização paralela. A munição do movimento estudantil foi direcionada toda sobre o trabalho da Equipe e também contribuiu para a paralisia que caracterizou suas atividades, mas a reforma universitária ocorreu por diversos meios.

O então criado Conselho de Reitores das Universidades Brasileiras - CRUB participou ativamente do movimento reformista, seja enviando dirigentes universitários para conhecerem o sistema universitário estadunidense, seja trazendo consultores estrangeiros que prestavam assessoria para implementar as modificações a fim de racionalizar as instituições brasileiras. O CRUB procurava viabilizar os temas de pesquisa e reformas estabelecidos pelo MEC-USAID.

As mudanças deram-se de forma paulatina em algumas universidades até serem generalizadas pela Lei $n^{0} 5.540 / 68$. O principal objetivo foi o da racionalização da universidade com vistas ao aumento do número de vagas. Assim, tomaram-se medidas como a diminuição da ociosidade do professor, a adoção do sistema de créditos, a reorganização da instituição universitária em departamentos e a extinção da cátedra

\footnotetext{
${ }^{8}$ United States Agency for International Development.
} 
vitalícia. Soluções de empresas capitalistas foram empregadas para os problemas universitários.

Beisiegel (1986) entende que a expansão de um nível de ensino, como a ocorrida com o superior, não se dá sem que ocorram algumas transformações. Estas podem ser organizacionais, de currículo ou de outras ordens.

Para Luiz Antônio Cunha,

A eliminação da 'duplicação de meios para fins idênticos ou equivalentes' foi um dos principais vetores da reforma universitária no período, buscando-se aumentar a produtividade dos recursos humanos e materiais existentes, bem como interligar as ilhas acadêmicas que a estrutura atomizada de faculdades/escolas/institutos definia como unidades quase independentes. (Cunha, 1988, p.319)

$\mathrm{O}$ aumento da demanda por Ensino Superior trouxe à tona um antigo plano do governo militar: a expansão desse nível por meio do modelo privado, que passou a ser estimulado.

A revisão do Plano Nacional de Educação, em 1965, passou a destinar 5\% do Fundo Nacional do Ensino Superior para subvencionar os estabelecimentos particulares do terceiro grau. Esse incentivo financeiro mais a contenção do crescimento dos estabelecimentos do setor público abriram amplas possibilidades para o setor privado no atendimento da demanda reprimida. Capitais tradicionalmente aplicados no ensino de $2^{\circ}$ grau, capitais recém investidos em cursinhos e capitais de outros setores de atividades transferiram-se para a exploração do promissor mercado do Ensino Superior. (Cunha, 1988, p.322)

Para Carlos Benedito Martins, em Ensino pago: um retrato sem retoques (1988), os investimentos do Estado, a partir de 1964, estariam voltados para a construção da infra-estrutura para a produção econômica, tendo, em contrapartida, uma diminuição do orçamento da educação, associada a um estímulo ao investimento privado nesse setor.

Portanto, a privatização do Ensino Superior brasileiro colocava-se perfeitamente dentro da lógica do regime implantado, e seria inclusive bem aceita pelo novo regime, pois desafogava o orçamento público. A iniciativa privada que começava a entrar em crise no ensino de $2^{\circ}$ grau, devido à expansão pública desta rede, passa a encontrar uma alternativa para seus negócios na criação de cursos superiores que passava a ser incentivada pelo governo federal. (Martins, 1988, p.69) 
Sofia Lerche Vieira, em Universidade federal nos anos 80: o jogo da política educacional (1990), relata que a normatização advinda com a Lei n $5.540 / 68$ teve como objetivo a racionalização e expansão das vagas e não atingiu o cotidiano pedagógico das universidades. As medidas foram ainda implementadas principalmente nas universidades públicas, ficando as particulares livres de uma fiscalização mais rígida por parte do governo:

O Ensino Superior, assim, no período subseqüente à promulgação da reforma de 1968, atravessa um surto expansionista que entra em ritmo de desaquecimento a partir de meados da década de setenta, e inicia os anos 80 sob o signo da contenção e recessão econômica. Os dados de crescimento do país e do Ensino Superior no período levam a crer que o aumento de vagas teria ocorrido de forma independentemente de ter, ou não, havido uma reforma universitária, tanto é que, em muitos aspectos, a expansão se fez à revelia do modelo definido pela Lei $\mathrm{n}^{\circ}$ 5.540/68 e legislação correlata. (Vieira, 1990, p.24-25)

A má qualidade do ensino privado foi observada, ainda em 1968, por Anísio Teixeira:

Considero hoje a expansão do ensino brasileiro o caso mais espantoso e grave de charlatanismo e demagogia, porque não estamos reformando o ensino, não estamos dando o ensino que devíamos à sociedade brasileira e estamos multiplicando indefinidamente instituições que antes deviam passar por profundas reformas. E chegamos a criar essa coisa paradoxal. Cria-se o Ensino Superior hoje com mais facilidade do que uma escola primária. Há estados cujos padrões escolares exigem, para se criar uma escola primária, professor e prédio. A escola superior nem de prédio precisa. Posso criá-la como quiser, num andar de um edifício, numa escola primária em funcionamento, ou passar a ter a escola superior à noite, num ginásio ordinário. Estou desenvolvendo escolas superiores como não desenvolveria escolas primárias. (Teixeira, 8 maio 1968, p.125)

O ensino ruim das novas escolas superiores particulares, em comparação às públicas, ressuscitou antigo problema, na visão de Bárbara Freitag:

As chances de trabalho, de salário, de vida, dos egressos da rede particular são sistematicamente menores na obtenção de um emprego que as dos formados pela rede oficial. Com a separação entre rede oficial e particular, reintroduziu-se a dualidade do antigo sistema educacional, que oferecia uma via para os filhos dos ricos e outra para os dos pobres. (Freitag, 1980, p.115, grifos do autor) 
O objetivo de diminuir a demanda continuou com a Lei $n^{0} 5.692 / 71$. Esta lei ampliou o ensino obrigatório para oito anos $\left(1^{\circ}\right.$ grau $)$ e o segundo ciclo do Ensino Médio ( $2^{\circ}$ grau $)$ adquiriu caráter profissionalizante. Com o aluno adquirindo o diploma de técnico ao término do ensino secundário, e sua conseqüente profissionalização, esperava-se que este não procurasse o nível superior. $\mathrm{O}$ texto da lei traduz melhor essa transformação no Art. $5^{\circ}$ :

par. $1^{\circ}$ - Observadas as normas de cada sistema de ensino, o currículo pleno terá uma parte de educação geral e outra de formação especial, sendo organizado de modo que:

a) no ensino de primeiro grau a parte de educação geral seja exclusiva nas séries iniciais e predominante nas finais;

b) no ensino de segundo grau, predomine a parte de formação especial.

par. $2^{\circ}$ - A parte de formação especial de currículo:

a) terá o objetivo de sondagem de aptidões e iniciação para o trabalho, no ensino de $1^{\circ}$ grau, e de habilitação profissional, no ensino de $2^{\circ}$ grau;

b) será fixada quando se destina a iniciação e habilitação profissional em consonância com as necessidades do mercado de trabalho local ou regional, à vista de levantamentos periodicamente renovados.

O governo, não tendo condições ou a prioridade de atender a procura pelo Ensino Superior, passou a oferecer uma alternativa de profissionalização para o estudante na etapa anterior, o que foi entendido como uma tentativa de afastar o formado das portas da universidade:

Em nível de $1^{\circ}$, mas especialmente de $2^{\circ}$ grau, as medidas de racionalização (ensino integrado, terminalidade) visavam criar profissionais de grau médio, diretamente aproveitáveis no mercado de trabalho e com isso desviar a atenção dos jovens dos cursos superiores. (Freitag, 1980, p.130)

Esta alternativa parece ter surtido pouco efeito. Alguns colégios procuraram apenas cumprir formalmente com a obrigação de oferecer cursos médios profissionalizantes a seus alunos, e em 1983 a habilitação passou a ser somente uma opção de cada escola. 
Apesar da expansão relatada, somente a partir de 1971 o ensino obrigatório passou a ser de oito anos, ou seja, as conquistas educacionais ainda eram muito recentes e tomavam corpo na sociedade brasileira lentamente. Ernst Hamburguer (1970) observa que as estatísticas educacionais indicam que, na época, cerca de 5\% dos estudantes que iniciavam o processo de escolarização concluíam o Ensino Médio e que apenas $1 \%$ atingiam o nível superior; os universitários eram ainda provenientes de uma camada favorecida sócio-economicamente. A partir desta constatação, propõe o sorteio das vagas no Ensino Superior.

Segundo ele, o sorteio traria vários benefícios. Os cursinhos talvez se transformassem em bons colégios de Ensino Médio, este nível de ensino não se basearia apenas no conteúdo exigido para ingresso no superior e descobrindo sua própria vocação, e o curso não seria privilégio de uma elite.

A proposta de sorteio ficou no plano das idéias, mas várias mudanças ainda ocorreriam diretamente no vestibular. Vianna (1986) relata que o decreto $n^{\circ} 68.908 / 71$ tornou o vestibular rigorosamente classificatório. Isto já acontecia em algumas áreas, em especial na área médica através do CESCEM - Centro de Seleção de Candidatos às Escolas Médicas. O decreto procurou unificar os vestibulares, de forma que era possível saber o número exato de candidatos que, quando espalhados por diferentes exames, se sobrepunham, inflacionando os números. As tentativas de unificação dos vestibulares tiveram resistências diversas, em especial das instituições particulares, cuja clientela se constituía da sobra dos vestibulares das oficiais.

Foi criada logo na seqüência a CONVESU - Comissão Nacional de Vestibular Unificado - que iria se encarregar de viabilizar as propostas de junção dos vários exames, e, também, obrigar que os conteúdos das provas fossem restritos ao ministrado no ensino secundário. Paralelamente a isto, as taxas de inscrição passaram a ser disciplinadas pela Comissão de Encargos Educacionais do Ministério da Educação, porque seu reajuste constante, que acompanhava a inflação, acabou tornando-as proibitivas para boa parte dos vestibulandos.

A seleção por meio de testes tornou-se obrigatória em 1973, entendida como adequada para a seleção de massas, pois eliminaria a subjetividade das avaliações. Em 1976 acrescentou-se a prova de redação, quando se constatou que vários alunos se matriculavam tendo pouca habilidade com a escrita. 
A unificação das provas foi determinada em 1975, com a exigência de que estas apresentassem o mesmo conteúdo programático por instituição. Isto contribuiu para o surgimento da FUVEST - Fundação Universitária para o Vestibular - que passou a organizar as provas para o ingresso na USP, UNESP e UNICAMP, antes divididas em áreas e organizadas pelo CESCEM (área de ciências biológicas e saúde), CESCEA (área de humanas) e MAPOFEI (área de exatas e tecnologias). Com a possibilidade da organização do exame por instituição de ensino, abandonou-se a proposta de unificação que originara a CONVESU.

Porém, a criação da FUVEST teve também outras motivações; em 1973 o CEPE - Conselho de Ensino, Pesquisas e Extensão de Serviços à Comunidade da USP - encaminhou pedido às autoridades federais para que ela pudesse adotar o critério de habilitação; este pedido, segundo Dias e Martelli, baseava-se em três pontos básicos:

a) o rebaixamento progressivo do nível dos alunos da USP, na média dos casos, em decorrência do sistema classificatório;

b) o dever da USP de não apenas manter o alto padrão de ensino e pesquisa que sempre a caracterizou, como também de aprimorar-se cada vez mais no sentido de fornecer ao país aquelas instituições de altos estudos de que ele tanto necessita;

c) o dever de decisão de uma universidade quanto ao tipo de aluno que nela irá ingressar. (Dias \& Martelli, 1978, p.23)

Mudanças na legislação de 1976 e 1977 acarretaram a volta dos exames habilitatórios e a existência de vagas ociosas quando originaram a exigência de conhecimento mínimo relativo ao $2^{\circ}$ grau por parte dos vestibulandos, gerando o estabelecimento de notas mínimas para aprovação. (Vianna, 1986, p.120)

O modelo que admitia vagas ociosas permaneceu por muitos anos; na FUVEST este só se extinguiu após o vestibular de 1990, quando deixaram de ser preenchidas 907 vagas das 6.802 oferecidas, o que ocasionou a realização de um segundo exame para as cadeiras não ocupadas. Nos exames subseqüentes suprimiram-se as notas mínimas e as provas eliminatórias. (Beisiegel, 1995)

A política educacional implementada no final da década de 1960 e início da seguinte vigorou praticamente durante duas décadas, com maior expansão do setor privado na educação superior em relação ao público, ampliação do atendimento nas escolas públicas de nível médio e vestibular descentralizado por instituição. 
Sofia Lerche Vieira (1990) relata que a troca constante de ministro da educação nos anos 1980 - foram nove pessoas que se revezaram nessa pasta - impediu que houvesse uma política sistematizada para o Ensino Superior naquela década. Entretanto, foi possível observar algumas importantes medidas e um intenso debate educacional.

As discussões giraram em torno da avaliação, autonomia e carreira docente. Os ministros sempre questionavam a questão da autonomia das IFES e da gratuidade proposta pelas associações de estudantes, professores e funcionários. A principal alteração ocorreu na carreira dos professores universitários, que conquistaram a isonomia salarial.

Alguns projetos receberam grandes investimentos financeiros, como o Programa Nova Universidade implementado pelo então ministro Marco Maciel, que consistia em distribuição de verbas às instituições privadas de ensino que apresentassem projetos, embora os critérios de avaliação apresentassem ausência de transparência.

As discussões na década de 1980 sobre a gratuidade do Ensino Superior e a autonomia das IFES, promovidas por órgãos de representação dos funcionários, professores, reitores e pelo governo, acabaram por influir no texto constitucional produzido no final daquele período.

\subsection{A atual legislação educacional - implicações no acesso ao Ensino Superior}

A Carta Magna de 1988 e a nova Lei de Diretrizes e Bases da Educação alteraram sensivelmente aspectos relacionados ao Ensino Médio, superior, e formas de ingresso.

A primeira grande modificação vinculada ao Ensino Médio encontra-se no inciso II do artigo 208 da Constituição Federal (CF) e atribui ao Estado o dever de garantir a "progressiva extensão da obrigatoriedade e gratuidade ao Ensino Médio". A redação deste inciso foi, posteriormente, modificada pela Emenda Constitucional $\mathrm{n}^{\circ}$. 14, de 12 de dezembro de 1996: “progressiva universalização do Ensino Médio gratuito". 
Desta forma a obrigatoriedade e gratuidade foram substituídas pela universalização, deixando o Estado numa posição mais confortável, no que tange ao oferecimento deste nível de ensino, embora a progressividade, sem qualquer meta associada, já livre o Estado de maiores obrigações. A universalização desta etapa, caso aconteça, trará grande contingente de candidatos ao ingresso na etapa seguinte da educação escolar. Na divisão de tarefas entre as três esferas, o oferecimento do Ensino Médio ficou como prioridade para os governos estaduais.

Ainda no inciso $\mathrm{V}$ do artigo 208 encontra-se algo relacionado diretamente à matrícula no Ensino Superior: "acesso aos níveis mais elevados do ensino, da pesquisa e da criação artística, segundo a capacidade de cada um".

Para Romualdo Portela de Oliveira, em Educação e cidadania: o direito à educação na constituição de 1988 da República Federativa do Brasil, este texto:

[...] reflete muito mais uma declaração de intenções que procuraria especificar a idéia liberal de "igualdade de oportunidades", do que um dispositivo com implicações objetivas. De qualquer forma, a expressão "segundo a capacidade de cada um" pode dar margem a justificar os tais exames de avaliação do perfil cognitivo do alunado como mecanismo de avaliação das escolas, ou a justificação de mecanismos de seleção do tipo exames vestibulares. (Oliveira, 1995, p.101)

Esse inciso constitucional acaba por estabelecer o mérito como condição de prosseguimento dos estudos. Dentro desta lógica, as políticas de ações afirmativas como o estabelecimento de cotas de ingresso para determinadas populações desfavorecidas na seleção para a universidade - ficam dificultadas, pois com elas os alunos poderiam garantir a matrícula sem ter demonstrado capacidade para tanto. Porém, se há desigualdade no perfil do aluno, isto pode ser confrontado com o princípio da igualdade de condições para acesso e permanência na escola, também presente na atual Constituição.

Já a LDB no 9394/96 estabelece, no inciso II do artigo 44, que os cursos de graduação serão: "abertos a candidatos que tenham concluído o Ensino Médio ou equivalente e tenham sido classificados em processos seletivos".

Assim, cai a obrigatoriedade de exames vestibulares, os quais podem ser substituídos por processos seletivos quaisquer, que podem incluir análise de currículos, entrevistas e outras formas definidas pela instituição. 
A transferência e a matrícula como aluno especial são outras possibilidades de acesso a cursos de graduação regulamentadas pela LDB:

Art. 49. As instituições de educação superior aceitarão a transferência de alunos regulares, para cursos afins, na hipótese de existência de vagas, e mediante processo seletivo prévio.

Art.50. As instituições de educação superior, quando da ocorrência de vagas, abrirão matrícula nas disciplinas de seus cursos a alunos não regulares que demonstrarem capacidade de cursá-la com proveito, mediante processo seletivo prévio.

A cada aluno evadido, as IES ficam obrigadas a abrir vagas para as finalidades acima descritas; porém, como a matrícula depende de seleção, o efeito pode ser inócuo. Mas o fato de ser necessário o oferecimento dessas vagas já constitui uma oportunidade extra para os alunos que não possuem condições financeiras para continuar pagando um curso, podendo pleitear concluí-lo na rede pública.

O ensino superior público teve a gratuidade assegurada no texto constitucional, bem como a subvenção por parte do Estado. A gratuidade existe de fato desde pelo menos os anos 1950; entretanto, toda a legislação anterior apontava para a sua irregularidade. Somente com a nova CF ela passa a existir de direito. (Cunha, 1991)

Por sua vez, o particular passou a ser livre, com avaliação de qualidade e autorização do Poder Público. Este também pode receber verbas públicas desde que comprove finalidade não lucrativa, aplique os excedentes em educação e destine o patrimônio - em caso de encerramento das atividades - a instituições filantrópicas, confessionais, comunitárias ou ao próprio Poder Público.

No artigo 207 da CF foi garantida também a autonomia universitária: "As universidades gozam de autonomia didático-científica, administrativa e de gestão financeira e patrimonial, e obedecerão ao princípio de indissociabilidade entre ensino, pesquisa e extensão".

A autonomia foi regulamentada na LDB, que estabeleceu o direito de o Poder Público avaliar e credenciar as IES periodicamente, e também sugerir alterações que, caso não cumpridas, podem implicar até o fechamento da instituição.

Essa normatização permitiu grande liberdade para as universidades, que passaram a não depender mais da autorização do Conselho Nacional de Educação 
(CNE) para criar, expandir, modificar ou extinguir cursos dentro de sua sede. Esta maior liberalização irá estimular a formação de novas universidades, fato descrito mais adiante.

O Conselho Nacional de Educação foi regulamentado pela Lei n ${ }^{\circ}$ 9.131/95 cuja aprovação foi anterior a da LDB; assim, esse importante órgão acabou não sendo incluso na LDB e ficou isolado da organização do ensino estabelecida pela LDB.

O artigo 1 da Lei 9.131/95 estabelece que o CNE e suas câmaras têm a função de colaborar com o Ministério da Educação e do Desporto; e que seus membros serão escolhidos pelo Presidente da República através de um sistema de indicação das entidades da sociedade civil relacionadas à área educacional. Já o artigo 2 prevê que as deliberações e pronunciamentos do CNE têm que ser homologadas pelo Ministro. Assim, as atitudes do CNE refletem mais a política governamental do que um eventual debate dos diversos segmentos ali representados.

Apesar dos membros serem indicados pelo governo e de suas decisões passarem pelo crivo do Ministério, o ministro Paulo Renato Souza ainda emitiu o Decreto 3.680/01 que, entre outras providências, restringe o poder do CNE e amplia o do Ministério, que passa a ter maior liberdade para autorização de novos cursos e fechamento de outros.

O CNE chegou no ano de 1999 a autorizar o funcionamento de 745 novos cursos superiores e, em 2000, outros 865. Denotando a política governamental expansionista no período. (Oliveira, jul./set. 2001)

As mudanças advindas com a Constituição Federal de 1988 e a nova LDB proporcionaram maior liberdade às universidades para administrar o oferecimento de suas vagas, a substituição do vestibular por processos seletivos diversos e um estimulo à expansão do ensino de nível médio.

\subsection{A recente expansão do Ensino Médio}

A expansão do Ensino Médio nas últimas décadas pode ser observada na Tabela 1. Nela, o crescimento da matrícula é superior ao incremento populacional, com a ampliação das oportunidades educacionais para outros setores da população que não apenas os estratos médios. 
Tabela 1: Crescimento populacional e freqüência ao Ensino Médio em alguns anos.

\begin{tabular}{|l|r|c|r|c|c|}
\hline Ano & $\begin{array}{c}\text { População } \\
\text { Estimada }\end{array}$ & $\begin{array}{c}\text { Crescimento } \\
\text { da população } \\
\text { com base em } \\
1968\end{array}$ & $\begin{array}{c}\text { Número de } \\
\text { matrículas } \\
\text { iniciais }\end{array}$ & $\begin{array}{c}\text { Crescimento } \\
\text { da matrícula } \\
\text { com base em } \\
1968\end{array}$ & $\begin{array}{c}\text { Porcentagem } \\
\text { da população } \\
\text { matriculada } \\
(\%)\end{array}$ \\
\hline $1968^{*}$ & 89.376 .000 & 100 & 801.075 & 100 & 0,90 \\
\hline 1978 & 116.393 .100 & 130 & 2.519 .122 & 314 & 2,16 \\
\hline 1988 & 144.427 .600 & 162 & 3.339 .930 & 417 & 2,31 \\
\hline 1998 & 158.232 .252 & 177 & 6.968 .531 & 870 & 4,41 \\
\hline 2001 & 169.369 .557 & 189 & 8.983 .866 & 1.121 & 5,03 \\
\hline
\end{tabular}

Fonte: IBGE/ Anuário Estatístico do Brasil 1970/1979/1989/ PNAD1998/2001

* considerou-se o número inicial de matrículas no colegial, o segundo ciclo do Ensino Médio da época.

Pode-se observar que após 1988, quando da promulgação da Carta Magna, acentua-se o crescimento da matrícula. Isto pode ser observado de forma mais detalhada na Tabela 2. Nesta, os dados de matrícula são fornecidos pelo MEC/INEP e apresentam diferenças com relação àqueles da Tabela 1, porque a forma de coleta é diferente; o IBGE entrevista as pessoas em sua residência por amostragem, enquanto os dados do MEC são obtidos junto às instituições escolares.

Tabela 2: Ensino Médio - matrícula inicial por dependência administrativa de 1988 a 2001.

\begin{tabular}{|l|r|r|r|r|r|}
\hline Ano & Total geral & Federal & Estadual & Municipal & Particular \\
\hline 1988 & 3.368 .150 & 98.297 & 2.039 .812 & 145.476 & 1.084 .565 \\
\hline 1991 & 3.770 .230 & 103.092 & 2.472 .757 & 176.769 & 1.017 .612 \\
\hline 1996 & 5.739 .077 & 113.091 & 4.137 .324 & 312.143 & 1.176 .519 \\
\hline 1997 & 6.405 .057 & 131.278 & 4.644 .671 & 362.043 & 1.267 .065 \\
\hline 1999 & 7.769 .199 & 121.673 & 6.141 .907 & 281.255 & 1.224 .364 \\
\hline 2000 & 8.188 .887 & 108.594 & 6.662 .711 & 264.135 & 1.153 .447 \\
\hline 2001 & 8.398 .008 & 88.537 & 6.962 .330 & 257.425 & 1.220 .324 \\
\hline $\begin{array}{l}\text { Crescimento \% } \\
(1988-2001)\end{array}$ & $149,3 \%$ & $-9,93 \%$ & $241,3 \%$ & $76,9 \%$ & $12,5 \%$ \\
\hline
\end{tabular}

Fonte: MEC/ INEP. Censo escolar 1998/ 1999/ 2000/2001.

Os governos estaduais têm sido os maiores responsáveis pelo atendimento neste nível de ensino, com 241,3\% de crescimento da matrícula inicial após o ano de 1988. Uma leitura mais atenta da Tabela 2 nos mostra ainda uma retração da matrícula nas outras redes a partir de 1997. 
Esse comportamento pode ser explicado pela promulgação da LDB 9394/96, que reorganizou as responsabilidades de cada esfera da união. Os Estados passaram a oferecer "com prioridade" o Ensino Médio, e os Municípios ficaram com a incumbência de assegurar o Ensino Fundamental e a Educação Infantil, e somente quando atendidos plenamente estes dois, atuar em outros níveis. É provável que com esta determinação alguns municípios tenham repassado aos governos estaduais suas escolas secundárias e assumido escolas primárias estaduais.

O ensino médio particular, que historicamente foi o responsável por boa parte do atendimento da demanda, em 1988 detinha 32,2\% das matrículas. Com a ampliação da oferta pública, essa participação decresceu, no ano 2000, para apenas 14,5\% do total das matrículas, com visível estagnação do número de alunos atendidos em torno de um milhão e duzentos mil.

A ampliação só foi possível por conta das modificações que melhoraram o rendimento do sistema escolar na etapa anterior. Várias políticas de correção de fluxo e combate à evasão e à repetência foram introduzidas no Ensino Fundamental. A organização do ensino em ciclos, as classes de aceleração, a recuperação de férias e os programas bolsa-escola foram algumas das novidades implementadas em várias regiões do país.

Assim, constata-se o que Beisiegel havia apontado como principal característica das mudanças educacionais das últimas décadas:

[...] a progressiva extensão das oportunidades de acesso à escola, em todos os níveis do ensino, para setores cada vez mais amplos da coletividade - ou, em outras palavras, o denominado processo de democratização do ensino - sem dúvida alguma aparece como o elemento central nas mudanças então observadas. (Beisiegel, 1993, p.38)

A despeito de uma maior parcela da população realizar a matrícula neste nível de ensino, Beisiegel aponta ainda grandes desigualdades no nível anterior de ensino, que se refletem no acesso ao médio.

Sampaio, Limongi e Torres, em Eqüidade e heterogeneidade no Ensino Superior brasileiro (2000), baseando-se em dados da Pesquisa Nacional por Amostra de Domicílios realizada pelo IBGE para o ano de 1997, constatam a desigualdade entre 
os concluintes do nível médio. Num extremo, apenas $2,9 \%$ dos jovens de cor preta ou parda, filhos de mães com baixa escolaridade e com renda familiar de até dois salários mínimos, conseguiram concluir o Ensino Médio. No outro extremo, 80,4\% dos jovens brancos, filhos de mães com mais de onze anos de estudo, renda familiar superior a 20 salários mínimos, tinham completado o Ensino Médio na idade correta, em 1997.

A democratização no Ensino Médio atingiu a jovens das mais diversas origens, mas não se deu de forma igual para todos. Este crescente contingente populacional atendido representa um incremento de candidatos habilitados ao nível superior, e uma maior pressão pela oferta de vagas, impulsionando algumas medidas de reforma do Ensino Médio e dos sistemas seletivos universitários.

\subsection{Perspectivas para o vestibular}

Além da expansão, o Ensino Médio passou por outras alterações na década de 1990. Entre elas, destaca-se a criação do Exame Nacional do Ensino Médio - ENEM e os novos parâmetros curriculares. Os vestibulares também foram alvo de modificações, principalmente com a liberalização da seleção provocada pela nova LDB.

O ENEM teve sua primeira aplicação em 1998, com cerca de 115 mil participantes. Nos anos seguintes, cresceram significativamente as inscrições, devido à adoção parcial de sua nota na avaliação dos vestibulandos das grandes universidades.

O objetivo principal do exame consiste em verificar se o aluno desenvolveu "as competências fundamentais ao exercício pleno da cidadania" (MEC/INEP, 1999). Quanto aos objetivos específicos, procura ser uma referência para o estudante nas suas escolhas futuras, seja para o ingresso no mercado ou para a continuidade dos estudos; auxiliar os processos seletivos no mercado de trabalho; e ser uma modalidade alternativa aos exames de acesso ao Ensino Superior.

Apesar de ser uma avaliação essencialmente individual, o ENEM pode ser utilizado para a avaliação de determinada unidade escolar caso esta atenda a algumas exigências: garanta que $90 \%$ dos concluintes estejam inscritos, proceda à divulgação do exame, e deposite uma importância adicional por estudante, além do valor da inscrição. 
O exame não possui suporte estatístico para ser utilizado como uma avaliação da rede de ensino, pois a inscrição é voluntária e os alunos da rede particular ainda têm de pagar uma taxa ${ }^{9}$, inviabilizando a existência de uma amostra confiável; mas é possível observar, nos meios de comunicação, comparações realizadas no desempenho dos estudantes segundo a dependência administrativa de suas escolas.

Em matéria publicada no jornal $O$ Estado de $S$. Paulo, com informações cedidas pelos organizadores do exame, mesmo isolando-se características como renda familiar e anos de estudo dos pais, o aluno da rede particular tem desempenho superior ao do aluno da pública. (Weber, 14 dez. 2000, p.A13)

Essa diferença no desempenho é importante, pois o principal argumento que sustentou a adoção do exame em algumas universidades públicas, em especial a USP, foi o de que a nota final favoreceria o ingresso dos alunos provenientes do ensino médio público. Na FUVEST a incorporação ou não da nota do exame alterou apenas em 2\% a classificação dos 150 mil candidatos. Para o diretor da fundação "os melhores alunos vão bem em qualquer tipo de exame de seleção." (Avancini, 27 ago. 2000. Soares, 24 a 30 mai. 1999. Macedo, 14 a 20 jun. 1999)

A despeito dos resultados publicados frustarem a expectativa inicial de um melhor resultado dos alunos do sistema público, o ministro Paulo Renato Souza espera que o exame substitua a primeira fase dos grandes vestibulares. Mas os planos são ainda mais ambiciosos, com a nota final sendo utilizada como referencial para a contratação de funcionários nas empresas, algo que já estava previsto nos seus objetivos e procura ser viabilizado através de reuniões entre os realizadores do exame e membros de organizações empresariais, como a Confederação Nacional da Indústria. (Weber, 9 ago. 2000. Athias, 30 ago. 1999)

O ENEM ainda estaria afinado com os novos parâmetros curriculares elaborados para aquele nível de ensino, e, como vimos, há nos seus objetivos uma grande ênfase na sua utilização para o mercado de trabalho. A maior ênfase no mercado de trabalho também está presente nos parâmetros. De acordo com Fogaça,

\footnotetext{
${ }^{9}$ Apenas no ano 2000 os alunos da rede pública passaram a realizar o exame gratuitamente; entretanto, comparações entre resultados de alunos provenientes do ensino público e particular já eram feitas desde 1999, e mesmo a inscrição gratuita não é garantia de que se consiga uma amostra confiável para que seja realizada uma comparação entre as duas redes de ensino.
} 
isto retomaria as questões suscitadas pela promulgação da Lei 5692/71: "Mais uma vez a política governamental se apóia na questão de terminalidade, isto é, no objetivo de dar aos concluintes do Ensino Médio algum tipo de preparo para o ingresso no mercado de trabalho.”. (Fogaça, 1999, p.61)

Além da inclusão do ENEM como novo elemento em diversos vestibulares, a liberalização, proporcionada pela LDB, vem ocasionando diversas transformações nos sistemas de seleção universitária.

Boa parte das novas iniciativa consiste numa combinação entre a avaliação contínua ao longo do Ensino Médio e o exame vestibular. Elas começaram a ser elaboradas ainda na década de 1980 e foram autorizadas a funcionar somente na década posterior.

A primeira experiência de alteração ocorreu antes da nova legislação. O Sistema de Avaliação Progressiva para Ingresso no Ensino Superior - SAPIENS -, elaborado pela fundação CESGRANRIO, iniciou-se ainda em 1993 com a autorização do MEC.

O sistema previa o acompanhamento do desempenho do aluno-candidato durante o curso de Ensino Médio, com o objetivo principal de substituir o vestibular tradicional. Ele também foi elaborado para não interferir na autonomia das escolas na organização dos conteúdos ministrados, não estimular a competição entre instituições, servir como uma avaliação do ensino para que a unidade escolar pudesse se utilizar dele para a tomada de decisões, estimular a participação dos professores na elaboração do exame e deixar a critério das IES a forma de aproveitamento dos resultados de cada aluno. Cada curso só poderia aceitar até 30\% de seus ingressantes pelo SAPIENS. (Carvalho, 1993, p.51-54)

A Universidade Federal de Santa Maria adotou o Programa de Ingresso ao Ensino Superior - PEIES - no ano de 1995 e seleciona 20\% de seus estudantes através deste programa; o restante das vagas é preenchido mediante o exame vestibular tradicional.

O PEIES tem como objetivos:

1. orientar, selecionar e classificar alunos-candidatos oriundos das escolas credenciadas da Região de Abrangência do PEIES (RAP), selecionar e classificar os demais candidatos através dos desempenhos obtidos nas Provas de Acompanhamento realizadas nas três séries do Ensino Médio; 
2. oferecer condições aos candidatos das escolas credenciadas (aluno-candidato) para, num período de três anos, poderem corrigir falhas individuais no processo de aprendizagem, bem como para descobrirem suas aptidões e optarem por profissões adequadas;

3. subsidiar as coordenações dos Cursos de Graduação da UFSM, a Secretaria de Educação do Estado do Rio Grande do Sul, Coordenadorias Regionais de Educação e Escolas credenciadas, com dados que revelem deficiência de aprendizagem do Ensino Médio, visando à adoção de medidas que proporcionem a redução das mesmas;

4. prover a UFSM de informações sobre candidatos, escolas e área de influência (geográfica, política, social, econômica, tecnológica, cultural e educacional), com o objetivo de melhor prepará-la para trabalhar com a diversidade de alunos que, anualmente, preenchem as vagas dos diferentes Cursos de Graduação. (UFSM, 2002)

O programa ainda prevê credenciamento de escolas da região, que participam anualmente do exame, e assistência aos professores, que se concretiza da seguinte forma:

As ações consistem num trabalho de qualificação oferecido em minicursos, oficinas, cadernos didáticos, videodisciplina, disque-disciplina, Caderno de Soluções, Caderno de Orientações Pedagógicas, Relatório de Desempenho Individual, programa radiofônico CLICK!, entre outras. Dentro desse programa de ações, é dada especial atenção à questão vocacional, visando formar um cidadão consciente de sua importância na sociedade em que vive e atua. (UFSM, 2002)

A avaliação é composta de três provas, uma ao final de cada ano letivo do Ensino Médio. A participação se dá através do pagamento de uma taxa. Além dos alunos da Região de Abrangência do PEIES, é aceita inscrição individual, mas a prova deve ser realizada no Município de Santa Maria, no Rio Grande do Sul.

Outras formas de seleção semelhantes foram introduzidas após a promulgação da nova LDB. O mais divulgado foi o Programa de Avaliação Seriada (PAS) da Universidade de Brasília.

O PAS é composto por três exames ao final de cada ano do Ensino Médio e tem como objetivo:

[...] a ampliação do processo de interação Universidade/Ensino Médio, incluindo a seleção dos candidatos a estudantes universitários na UnB, o PAS chega como uma forma de amenizar o impacto da passagem para o Ensino Superior. (UnB, 2002) 
O programa também procura uma maior interação entre os dois níveis de ensino:

Os conteúdos programáticos [...] foram propostos por comitês constituídos por professores de escolas públicas e particulares, e da própria UnB, e aprovados em fóruns abertos a todos os interessados. Isso significa, ao contrário do que acontece tradicionalmente, que o conhecimento a ser exigido foi definido por professores que conhecem a realidade das escolas e que buscaram selecionar o que é realmente importante de cada disciplina. O PAS não enfatiza a memorização de fórmulas, regras e classificações. É fundamental que o aluno seja capaz de compreender, raciocinar e analisar questões realmente relevantes para a sua formação como cidadão consciente e capaz de opinar criticamente a respeito de problemas da atualidade e de modificar a sociedade em que vive. $(\mathrm{UnB}, 2002)$

Para os ingressantes por esse sistema são reservadas $50 \%$ das vagas daquela universidade. Os alunos inscritos no programa ainda podem concorrer a uma vaga pelo vestibular.

Outro sistema é o realizado pela Universidade Federal de Ouro Preto e denominado SEI - Seleção por Etapas para Ingresso. O aluno pode ingressar pelo vestibular, pela SEI, e ainda aproveitar as notas da SEI no exame vestibular. Mas não há percentual de vagas fixas para uma ou outra forma de seleção.

As notas da SEI são comparadas com as do vestibular tradicional e os melhores colocados podem se matricular. No caso do candidato ter participado da SEI e do vestibular, serão consideradas as melhores notas obtidas em cada uma das provas.

Carlos Alberto Serpa de Oliveira (1987) entende que a avaliação no decorrer do Ensino Médio possui inúmeras vantagens quando comparada ao vestibular tradicional. Ela permitiria a aluno, professor e escola identificar e corrigir possíveis deficiências de ensino durante o aprendizado; dilui a tensão existente em um único exame, eliminando o seu caráter episódico; eliminaria os cursinhos preparatórios; e permitiria a avaliação de um maior número de atributos.

Nas justificativas desse modelo de seleção, ainda há argumentos que ressaltam a aproximação entre aluno, professor, escola e universidade como fator positivo em relação ao vestibular tradicional. O intercâmbio entre as diversas esferas reduziria a 
distância entre os pré-requisitos para ingresso no superior e a avaliação no Ensino Médio.

Todavia, são várias as críticas à avaliação estabelecida no decorrer do Ensino Médio. Zaia Brandão (1987) entende que a recuperação da qualidade de ensino não passa pela reforma do vestibular; ela seria conseqüência de políticas mais amplas, como aumento salarial e políticas de qualificação para o corpo docente.

Heraldo Vianna (1987) ressalta que não devem ser confundidos os objetivos de avaliação de aprendizagem do nível médio com o da verificação dos pré-requisitos estabelecidos para o curso universitário; que o processo seria mais oneroso que o realizado em um único período; e que ele poderia gerar tensão durante todos os três anos em que seriam realizadas as provas.

Ernst Hamburguer (1987) não vê vantagens para o aluno na avaliação seqüencial e não entende que esta poderia alterar o perfil sócio-econômico do estudante universitário.

Rubem Alves (6 fev. 1995) critica sistemas de seleção que distribuem toda a tensão de um único exame para toda a vida escolar. Além disto, eles não alteram a forma perversa de organização do conhecimento perpetuada pelo vestibular, e, para os alunos pobres, o ingresso ficaria ainda mais distante, pois eles não teriam como manter condições de competição por três longos anos; entretanto, podem se esforçar (monetariamente) uma única vez pagando um cursinho e conseguir uma vaga numa boa universidade no sistema de vestibular tradicional. O grande benefício destes novos sistemas, para o educador, seria a extinção dos cursos preparatórios.

Outra característica seria a regionalização dos exames. Muitos deles podem beneficiar, até propositadamente, os candidatos residentes na região onde o curso é oferecido.

Já em universidades particulares, onde a procura costuma ser numericamente inferior à dos cursos públicos, pode-se observar a adoção da nota do ENEM como critério único de ingresso, e outras formas, que incluem entrevistas e análise do currículo do Ensino Médio do candidato, modelos aplicáveis quando há um menor número de candidatos por vaga.

A adoção de uma prova nacional que balize o acesso ao Ensino Superior é utilizada em vários países. 
No Chile, a Prueba de Aptitudes Académicas, além de servir como critério seletivo para as universidades, também é utilizada para distribuição de créditos fiscais entre as instituições de ensino que a adotam, sendo que aquelas que possuem maior número de estudantes com melhor desempenho nos testes recebem os créditos. A prova é organizada pelo Conselho de Reitores e executada pelo Departamento de Avaliação, Medição e Registro Educacional da Universidade do Chile, e sua adoção não exclui a possibilidade de que, em determinadas carreiras, haja exames específicos. (Donosco, 1998; Esquivel Larrondo, 1995)

$\mathrm{Na}$ Argentina, a universidade é aberta a todos os concluintes do Ensino Médio que desejarem o ingresso. No entanto, desde 1994, procura-se estabelecer um Certificado Nacional de Aptidões Básicas que deve balizar os sistemas de admissão das universidades.

Nos Estados Unidos da América, a seleção é realizada pelas próprias instituições de Ensino Superior, entretanto quase todas adotam os exames SAT Scholastic Aptitude Test - e o ACT - American College Testing - como critérios de avaliação. A necessidade da adoção destes surgiu pelas características daquele país, que não possui um currículo nacional de Ensino Médio e tem grande trânsito de alunos universitários entre os diversos Estados. Assim, houve a necessidade de utilização de algum critério nacional que auxiliasse as instituições de ensino a avaliar a capacidade dos alunos. Os exames privilegiam o conhecimento de habilidades em língua inglesa, matemática, e noções científicas. (Ferguson, 1997)

$\mathrm{Na}$ França, o acesso à universidade é aberto a todos os que terminam o segundo grau e possuem o baccalauréat, independentemente de terem feito um segundo grau profissionalizante, tecnológico ou geral. Este exame é organizado em escala nacional, mas não é semelhante para todos os alunos, variando por região. Em alguns cursos e escolas, a avaliação incorpora outros elementos além do exame, definidos pela própria instituição, e o acesso se faz mais restrito. (Euriat, 1997)

Vê-se que a opção brasileira por um exame nacional de ensino médio não se dá de forma isolada. Mas as várias mudanças que estão ocorrendo parecem passar ao largo dos vestibulares com grande número de candidatos, como os da FUVEST, UNICAMP e UFMG, que ainda utilizam duas fases de seleção, em que a primeira, composta de testes de múltipla escolha, serve como guilhotina para eliminar o grosso 
dos vestibulandos. Entretanto, a nota do ENEM já compõe o resultado final em vários casos.

É provável que, com a expansão do Ensino Superior, o ENEM comece a ser adotado como critério único de ingresso naquelas IES que fiquem com as sobras dos vestibulares mais concorridos.

\subsection{A recente expansão do Ensino Superior}

O número de matrículas no Ensino Superior nas últimas décadas, como nos mostra a Tabela 3 , cresceu não apenas em números absolutos, mas também relativos à população.

Tabela 3: Crescimento populacional e freqüência ao Ensino Superior em alguns anos.

\begin{tabular}{|c|r|c|r|c|c|}
\hline Ano & $\begin{array}{c}\text { População } \\
\text { Estimada }\end{array}$ & $\begin{array}{c}\text { Crescimento da } \\
\text { população com } \\
\text { base em 1968 }\end{array}$ & $\begin{array}{c}\text { Número de } \\
\text { matrículas }\end{array}$ & $\begin{array}{c}\text { Crescimento } \\
\text { da matrícula } \\
\text { com base em } \\
1968\end{array}$ & $\begin{array}{c}\text { Porcentagem } \\
\text { da população } \\
\text { matriculada }\end{array}$ \\
\hline 1968 & 89.376 .000 & 100 & 278.295 & 100 & $0,31 \%$ \\
\hline 1978 & 116.393 .100 & 130 & 1.225 .557 & 440 & $1,05 \%$ \\
\hline 1988 & 144.427 .600 & 162 & 1.503 .555 & 540 & $1,04 \%$ \\
\hline 1998 & 158.232 .252 & 177 & 2.125 .958 & 764 & $1,34 \%$ \\
\hline 2001 & 169.369 .557 & 189 & 3.030 .754 & 1089 & $1,79 \%$ \\
\hline
\end{tabular}

Fonte: MEC/INEP, Evolução do Ensino Superior 1980-1998; IBGE, Anuário Estatístico do Brasil 1968/1978/1989; Pesquisa Nacional por Amostragem Domiciliar, 1998/2001.

Esse crescimento só foi possível devido ao crescimento do nível médio, como observável na Tabela 1. Em ambos os casos, houve uma maior parcela da população atendida. Desta forma, confirma-se o que Beisiegel (1986) já havia constatado como um fenômeno nacional: o deslocamento das aspirações sociais para os níveis mais elevados de ensino e a conseqüente democratização.

As universidades, as faculdades integradas e os centros universitários têm sido os principais responsáveis pelo crescimento da matrícula no período analisado. Isso pode ser observado na Tabela 4. 
Tabela 4: Ensino Superior - evolução da matrícula em cursos de graduação presencial por organização acadêmica 1988/2001.

\begin{tabular}{|l|r|r|r|r|}
\hline Ano & Universidades & $\begin{array}{r}\text { Fac. Integradas e } \\
\text { Centros Universitários }\end{array}$ & $\begin{array}{r}\text { Estabelecimentos } \\
\text { Isolados }\end{array}$ & Total \\
\hline 1988 & 770.240 & 201.744 & 531.571 & 1.503 .555 \\
\hline 2001 & 1.956 .542 & 504.435 & 569.777 & 3.030 .754 \\
\hline Cresc.(\%) & $154,0 \%$ & $150,0 \%$ & $7,2 \%$ & $101,6 \%$ \\
\hline
\end{tabular}

Fonte: MEC/INEP, Evolução do Ensino Superior 1980-1998; MEC/INEP, Sinopse Estatística do Ensino Superior, 2001.

A distinção do número de matrícula entre faculdades integradas e centros universitários ainda não existia em 1988; mas na Sinopse Estatística do Ensino Superior 2001, os centros universitários são responsáveis por $11,2 \%$ do total dos estudantes, enquanto as faculdades integradas respondem por 5,48\%.

Apesar do crescimento da matrícula em estabelecimentos públicos, a Tabela 5 indica que o particular ainda é o principal responsável pela expansão das vagas.

Tabela 5: Ensino Superior - evolução do número de vagas no vestibular em cursos presenciais de graduação por dependência administrativa 1988/2001.

\begin{tabular}{|l|r|r|r|r|r|}
\hline Ano & Federal & Estadual & Municipal & Particular & Total \\
\hline 1988 & 68.370 & 52.480 & 28.943 & 313.946 & 1.503 .555 \\
\hline 2001 & 123.531 & 101.805 & 31.162 & 1.151 .994 & 3.030 .754 \\
\hline Cresc. $(\%)$ & $80,7 \%$ & $93,9 \%$ & $0,8 \%$ & $266,9 \%$ & $101,6 \%$ \\
\hline
\end{tabular}

Fonte: MEC/INEP, Evolução do Ensino Superior 1980-1998; MEC/INEP, Sinopse Estatística do Ensino Superior, 2001.

$\mathrm{Na}$ Tabela 6 fica claro que o setor privado expande-se principalmente através das universidades; as faculdades integradas, centros universitários e estabelecimentos isolados até se multiplicam, mas o grande contingente de matriculados está concentrado nas organizações mais complexas. 
Tabela 6: Ensino superior privado por organização acadêmica, número de unidades e matrícula 1988/2001.

\begin{tabular}{|l|r|r|r|r|r|r|}
\hline \multirow{2}{*}{ Ano } & \multicolumn{2}{|c|}{ Universidades } & \multicolumn{2}{c|}{$\begin{array}{c}\text { Fac. Integradas e } \\
\text { Centros Universitários }\end{array}$} & \multicolumn{2}{c|}{$\begin{array}{c}\text { Estabelecimentos } \\
\text { isolados }\end{array}$} \\
\cline { 2 - 8 } & Unidades & Matrículas & Unidades & Matrículas & Unidades & Matrículas \\
\hline 1988 & 31 & 318.812 & 66 & 200.779 & 541 & 398.613 \\
\hline 2001 & 85 & 1.139 .629 & 161 & 493.538 & 962 & 458.362 \\
\hline
\end{tabular}

Fonte: MEC/INEP, Evolução do Ensino Superior 1980-1998; MEC/INEP, Sinopse Estatística do Ensino Superior 2001.

No inciso IV do Art. 53 da atual LDB, é regulamentada a autonomia que prevê o direito da universidade de "fixar o número de vagas de acordo com a capacidade institucional e as exigências de seu meio". Com isto, a expansão de vagas num mesmo curso deixa de ser regulamentada por normas gerais da União ou do respectivo sistema de ensino, embora a criação de novos cursos ainda dependa de autorização externa quando assim regulamentado.

Para Schwartzman, isso se tornou um atrativo para as IES particulares:

Esta maior autonomia levou a um grande movimento das instituições isoladas do setor privado para conquistar o status universitário, pelo cumprimento dos requisitos mínimos definidos pelo Conselho Nacional de Educação (CNE). Hoje a grande maioria dos estudantes brasileiros está matriculada em algum tipo de universidade, mas a distinção entre instituições universitárias e não universitárias, como critério para identificar qualidade acadêmica e de formação profissional, continua fazendo pouco sentido e se tornou ainda mais difusa com a criação de novas categorias intermediárias, como "centros universitários" e "faculdades integradas". (Schwartzman, 1999, p.3)

Assim, o decréscimo da matrícula em instituições isoladas e a quase estagnação nas faculdades integradas e centros universitários podem ser explicados pela criação das universidades particulares a partir da agregação destes dois tipos de estabelecimento.

A Tabela 7 retrata a evolução das universidades no período de 1988-2000. Há um grande incremento das instituições estaduais e particulares, enquanto as instituições federais têm um crescimento tímido. 
Tabela 7: Ensino Superior - evolução do número de universidades por dependência administrativa 1988/2001.

\begin{tabular}{|l|r|r|r|r|r|}
\hline Ano & Federal & Estadual & Municipal & Particular & Total \\
\hline 1988 & 35 & 15 & 2 & 31 & 83 \\
\hline 2000 & 39 & 30 & 2 & 85 & 156 \\
\hline Cresc. (\%) & $11,4 \%$ & $100,0 \%$ & $0,0 \%$ & $174,2 \%$ & $87,9 \%$ \\
\hline
\end{tabular}

Fonte: MEC/INEP, Evolução do Ensino Superior 1980-1998; MEC/INEP, Sinopse Estatística do Ensino Superior, 2001.

As instituições municipais são poucas e representam uma pequena parcela de matrículas. Suas características são analisadas por Carlos Benedito Martins:

Municípios que ainda não conseguiram oferecer, a contento, uma educação fundamental para a sua população, assim como outros serviços públicos elementares, embarcaram neste empreendimento academicamente incerto, porém rentável sob o ponto de vista da conquista ou da conservação do poder político. Diga-se de passagem que, apesar de ostentarem um estatuto de instituição pública, muitos desses estabelecimentos cobram mensalidades escolares e estão sob o controle de uma aliança de grupos político-partidários e empresários da educação. (Martins, 1993, p.56)

A criação de novas universidades estaduais está aliada à reformulação das Constituições Estaduais ocorrida após a promulgação da Carta Magna de 1988. Oliveira e Catani mostram que várias destas Constituições previam a abertura de cursos:

Sobre o Ensino Superior, fica clara a preocupação em expandir a rede pública, quer pelo desdobramento e ampliação de vagas em universidades já existentes, quer pela criação de novas. O que não fica claro é se os Estados avaliaram corretamente suas possibilidades de manter bom padrão de ensino, pesquisa e extensão criando novas universidades, provavelmente acima de suas condições financeiras. (Oliveira \& Catani, 1993, p.121)

Apesar da abertura de novas universidades federais estar praticamente estagnada nessa década, houve uma ampliação das vagas, principalmente no período noturno, conforme indica a Tabela 8. 
Tabela 8: Ensino Superior - matrícula do turno noturno, segundo natureza e dependência administrativa. Brasil 1991/ 2001.

\begin{tabular}{|l|r|r|r|}
\hline & $\begin{array}{r}\text { Vagas Noturnas em } \\
1991\end{array}$ & $\begin{array}{r}\text { Vagas Noturnas em } \\
2001\end{array}$ & \multicolumn{1}{c|}{ Crescimento (\%) } \\
\hline Federal & 50.196 & 123.603 & $146,2 \%$ \\
\hline Estadual & 94.087 & 158.502 & $68,5 \%$ \\
\hline Municipal & 66.805 & 60.010 & $-10,2 \%$ \\
\hline Privada & 650.688 & 1.392 .721 & $114,0 \%$ \\
\hline Total & $\mathbf{8 6 1 . 7 7 6}$ & $\mathbf{1 . 7 3 4 . 9 3 6}$ & $\mathbf{1 0 1 , 3 \%}$ \\
\hline
\end{tabular}

Fonte: MEC/INEP, Evolução do Ensino Superior 1980/1998; MEC/INEP, Sinopse Estatística do Ensino Superior, 2001.

Os cursos noturnos nas universidades federais, que em 1991 representavam apenas $15,7 \%$, crescem para $24,6 \%$ do total das matrículas efetuadas. A expansão noturna, quando realizada em cursos existentes, pode representar economia de investimentos, uma vez que já há infra-estrutura (prédios, bibliotecas, laboratórios etc.) e quadro de professores, tendo-se apenas de realizar alguns ajustes nos regimes de trabalho, contratação de docentes e funcionários.

Apesar do crescimento geral do Ensino Superior no período analisado, Sampaio, Limongi e Torres, observando a presença do jovem de 18 a 24 anos neste nível, constatam que poucos chegam a se matricular, mas que muitos deles podem ou poderão se candidatar ao superior em breve:

Cabe destacar, porém, que outra parcela importante de jovens poderia vir a ingressar no Ensino Superior, constituindo a clientela potencial do Ensino Superior; essa importante parcela engloba os 2,5 milhões de jovens que concluíram o Ensino Médio (onze anos de estudo) e que não estão atualmente estudando e os 2,3 milhões de jovens que, na faixa de 18 a 24 anos, ainda estão cursando o Ensino Médio (oito a dez anos de estudo). (Sampaio, Limongi \&Torres, 2000, p.15)

O Ensino Superior cresce principalmente através de universidades particulares e parece ser improvável que o setor público invista maciçamente na abertura de novas universidades ou cursos isolados; a expansão da oferta pública tende a se concentrar no período noturno de cursos já estruturados. 


\subsection{Perspectivas de reestruturação do Ensino Superior}

A política do governo militar para a educação superior criou uma cisão entre as atividades desenvolvidas em instituições públicas e particulares. Ficando, grosso modo, as oficiais responsáveis pelas atividades de pesquisa e o ensino de qualidade, e as outras com a atribuição de atender à crescente demanda com cursos de baixa qualidade.

O governo Fernando Henrique Cardoso desenhou uma série de ações visando corrigir as distorções criadas no passado - quando a expansão do ensino particular primou pela má qualidade e a expansão do público tornou-se onerosa demais - e projetar um crescimento para os próximos períodos. As mais relevantes podem ser assim descritas:

a) reestruturação das atividades das IFES através da remuneração por produtividade e maior autonomia administrativa, com o fim da má utilização dos recursos;

b) fim da aposentadoria integral para professores universitários federais;

c) política de expansão do ensino particular para o atendimento massificado da demanda por Ensino Superior;

d) melhora da qualidade dos cursos oferecidos através da implementação do Exame Nacional de Cursos (Provão), que estabelece a concorrência como estímulo para a melhora dos cursos;

e) implementação de um sistema de crédito educativo baseado em empréstimos bancários;

f) criação de fundo, para o financiamento do Ensino Superior, que distribua recursos conforme a produtividade, aferida via Provão e outros indicadores de performance.

A maior autonomia administrativa das IFES tem como objetivo proporcionar maior liberdade de aproveitamento dos recursos financeiros para a reestruturação das atividades internas. Num primeiro momento, tentou-se transformar as universidades federais em fundações de direito privado através da criação de Organizações Sociais que seriam públicas não-estatais. Devido às pressões recebidas, principalmente por setores estudantis e pelo professorado, esta transformação tornou-se voluntária. (Cunha, 1999) A tentativa de alteração gerou críticas às propostas governamentais e inúmeros debates sobre qual conceituação e modelo de autonomia são ideais.

Articula-se com essa o fim da aposentadoria integral dos professores. Considerada onerosa demais, ela ainda estimularia trabalhadores intelectuais -aqueles que adquirem maior produtividade com o decorrer dos anos - à saída precoce do trabalho.Visando extingui-la, ou pelo menos aliviar os custos para o governo, o projeto proposto 
pretendia incorporá-la aos gastos das universidades, num modelo próximo ao das universidades estaduais paulistas. Atualmente, o projeto passa pela contratação dos docentes pela Consolidação das Leis Trabalhistas, regime que estabelece um teto para a aposentadoria. Um grande defensor e idealizador destas reformas é o ex-ministro da administração e reforma do estado Luiz Carlos Bresser Pereira. De acordo com ele:

O essencial é, gradualmente, tornar as universidades fundações autônomas, de direito privado, que contratem professores e funcionários pela legislação trabalhista e organizem fundos de pensões para eles. (Pereira, 4 jun. 2000, p.1011)

Eunice Durham (1998) ressalta a má utilização dos recursos nas IFES. Suas críticas podem ser assim sistematizadas:

a) alto número de funcionários e docentes por aluno, inclusive quando comparado a grandes universidades de pesquisa internacionais;

b) ausência de estímulos para ampliação de novos cursos ou fechamento de deficitários;

c) o baixo salário do professor é recompensado com vantagens corporativas e não está associado à competência e à produtividade;

d) nem todas as IFES apresentariam indicadores de pesquisa relevantes para o montante de dinheiro recebido;

e) o regime de dedicação exclusiva é utilizado de forma irracional, com algumas instituições que apresentam baixa produção científica e muitos docentes inscritos neste regime de trabalho.

Nem todos compartilham este ponto de vista. Nos cálculos apresentados por Durham são incluídos como gastos os hospitais universitários e funcionários aposentados, o que não seria admitido em cálculos internacionais de custo aluno (USP/IEA, 2000). Nelson Cardoso do Amaral (1999) ressalta, ainda, que cerca de 30\% da folha de pagamento dos funcionários técnicos e administrativos das IFES é relativa a trabalhadores alocados nos diversos hospitais existentes.

Outra contradição na política governamental seria que, apesar da defesa da autonomia universitária, não se abdicou, por exemplo, da escolha de reitores pela lista tríplice e tampouco da definição dos critérios de remuneração da atividade docente através da Gratificação de Estímulo à Docência (GED). A remuneração por 
produtividade, em vigor através da GED, privilegia as atividades de docência em relação às de pesquisa, extensão e administração no trabalho do professor (Catani \& Oliveira, 1999).

Alguns itens do orçamento das IFES também passaram a ser redimensionados de acordo com os indicadores de desempenho de cada instituição. Medir a produtividade de uma universidade através de uma avaliação ancorada em indicadores como taxa de evasão, destino profissional, número de vagas, dentre outros, também não é algo tão simples. Alguns aspectos fundamentais que caracterizam o trabalho universitário seriam de difícil mensuração, como, por exemplo, a qualidade acadêmica do trabalho, a reinterpretação de fatos realizada pelos alunos e a relevância social do conhecimento produzido. (Dias Sobrinho, 1999)

A estratégia governamental de expansão do setor privado vem acompanhada de um sistema avaliativo, o Exame Nacional de Cursos (Provão), que visa à garantia de qualidade nessas instituições, procurando não incorrer em "erros do passado", quando a simples proliferação, ausente de uma fiscalização mais rígida, produziu um Ensino Superior de baixa qualidade.

O Provão baseia-se no pressuposto de que a concorrência entre os diversos cursos possa garantir a qualidade. De início, as IES foram classificadas por notas - A, B, C, D ou E - distribuídas conforme a curva de Gauss (conhecida também como curva do sino ou normal). Neste sistema sempre existiriam cursos localizados nas extremidades, independente de haver diferenças entre cursos situados numa mesma faixa de nota. Não se esperava, portanto, que todos os cursos chegassem a um patamar aceitável de qualidade. Após algumas reclamações o sistema de distribuição de notas foi alterado, mas ainda se espera que as notas divulgadas sirvam como estímulo para uma melhora dos cursos.

O Provão já vem sendo utilizado de diversas formas. Algumas instituições chegam a divulgar a nota obtida visando à publicidade. O Ministro da Educação também chegou a encaminhar pedido de fechamento de alguns cursos que apresentaram nota $\mathrm{E}$ durante várias avaliações seguidas para o Conselho Nacional de Educação.

Procura-se ainda distinguir entre os vários tipos de ensino privado existentes. Este esforço pôde ser percebido na Lei de Diretrizes e Bases que estabeleceu 
diferenças entre as instituições de ensino filantrópicas, confessionais, comunitárias e de caráter estritamente privado. Algumas medidas provisórias e decretos do Ministro da Educação procuraram regulamentar o disposto na lei.

A regulamentação tem como objetivo um maior controle sobre as atividades particulares, combatendo a evasão fiscal e fiscalizando as isenções concedidas. Com a resistência das privadas a perder certos benefícios, o governo por várias vezes voltou atrás em suas resoluções. Esta normatização interessa também às universidades comunitárias, que, distinguindo-se daquelas que possuem fins lucrativos, esperam abocanhar maior parcela de recursos públicos. (Cunha, 1999)

Foi criado um novo programa de crédito educativo no final de 1998, batizado de FIES - Financiamento Estudantil -, em substituição ao CREDUC existente desde a década de 1970.

O CREDUC repassava dinheiro diretamente às IES, que ficavam responsáveis pela concessão das bolsas de estudo. $\mathrm{O}$ aluno iniciava o pagamento do benefício um ano após o término da bolsa. $\mathrm{O}$ valor da dívida era reajustado com juros anuais de $6 \%$ e de acordo com a TR - taxa referencial de juros - utilizada na correção de financiamentos. A alta inadimplência dos beneficiados pelo programa gerou prejuízos da ordem de R \$ 1,6 bilhão, valor assumido pela Caixa Econômica Federal, que comprou a carteira débito anterior por $\mathrm{R} \$ 300$ milhões (Valente, 12 jun. 1999, p.1-3). $\mathrm{Na}$ tentativa de realizar a cobrança dos atrasados, a CEF procurou incluir o nome dos inadimplentes em cadastros restritivos ao crédito, mas liminares na justiça proibiram esta inclusão e ainda garantiram que as dívidas de 46 mil alunos fossem recalculadas sem a cobrança da TR. (FSP, 5 fev. 2000, p.3-4)

A implantação do FIES foi antecedida por dois fatos; em 1997, o governo fechava as inscrições para o financiamento e não cumpria o prazo de repasse de verbas para as universidades conveniadas. Para ambas ações, o governo alegou a alta inadimplência no CREDUC, pois sem a efetivação do pagamento pelos estudantes, não havia recursos para repassar às IES bem como para continuar abrindo novas inscrições. (Rosseti, 4 dez. 97: 3-4)

Procurando corrigir as deficiências do programa anterior, o FIES adquiriu as seguintes características:

- foi eliminado o ano de carência entre a formação e o início do pagamento; 
- o aluno deve depositar uma quantia de $\mathrm{R} \$ 50,00$ trimestralmente, com vistas ao abatimento dos juros de $9 \%$ ao ano;

- procurou-se observar a renda familiar dos estudantes para que o pagamento das mensalidades não comprometesse $60 \%$ do orçamento;

- são requeridos de um a quatro fiadores que possuam no total renda superior a duas vezes o valor da mensalidade;

- o FIES cobre apenas $70 \%$ do valor da mensalidade, e o estudante fica responsável pelo pagamento do restante (ele não necessita utilizar todo o crédito obtido);

- o estudante tem o prazo de uma vez e meia a duração do curso para iniciar o pagamento;

- a universidade e a agência financiadora ficam responsáveis por parte do pagamento em caso de inadimplência, cabendo à primeira arcar com $10 \%$ dos prejuízos, e à segunda, $20 \%$;

- na distribuição dos benefícios serão privilegiados o Estado e as IES que apresentarem maior número de pedidos, recebendo o proporcional em créditos;

- o repasse às IES deixa de ser em dinheiro e passa a ser feito através de Certificados Financeiros do Tesouro Série E (CFTs), que possibilitam o pagamento de contribuições previdenciárias;

- a manutenção do financiamento está associada ao desempenho do aluno, que deve ter $75 \%$ de freqüência nas disciplinas cursadas para não ser cortado do programa;

- opção pelo financiamento de cursos mais baratos (preferencialmente os de licenciatura) com vistas a atingir um maior número de pessoas com menor quantidade de recursos;

- a necessidade do curso ter sido bem avaliado no Provão, não podendo ter recebido nota D ou E.

O novo programa, procurando corrigir as deficiências do anterior, visa garantir que o aluno, depois de formado, salde sua dívida, e, com o retorno do dinheiro investido, ocorra a concessão de novas bolsas. A exigência de fiador, a inclusão da universidade como devedora solidária e a verificação da renda familiar do candidato são as várias formas pelas quais o governo procurou garantir que o empréstimo fosse saldado. 
Associação Brasileira de Universidades Comunitárias fez várias críticas ao FIES. O repasse em CFTs - em substituição ao modelo anterior que era realizado em dinheiro -, o fato de o valor repassado ser superior às despesas com encargos previdenciários, o envolvimento das IES como devedoras solidárias ao aluno em caso de inadimplência e a perda de um ano extra após o término do curso para o início do pagamento foram as características do programa mais criticadas pela ABRUC.

A UNE protestou contra o alto número de exigências, que acabava inviabilizando a obtenção do financiamento e excluindo justamente os mais pobres. Para a entidade estudantil deveriam ser excluídos do FIES apenas os que possuem condições de pagar seus estudos. (FSP, 15 nov. 1999, p.2-5)

Numa primeira seleção realizada no FIES, 55\% dos requerimentos foram desclassificados por terem renda familiar insuficiente. No resultado final, $84 \%$ dos alunos selecionados possuíam renda familiar de R\$ 2.500,00 em média. (Floresta, 09 out. 1999. Silva \& Floresta, 09 out. 1999)

O financiamento ainda priorizaria o investimento na formação em carreiras de baixo custo, e, desta forma, o estudante pobre não teria a possibilidade de cursar carreiras mais dispendiosas, como medicina, odontologia e engenharia, que poderiam proporcionar maior retorno financeiro e status social.

Para o governo federal o programa não excluiria os mais carentes, mas aqueles que optam por cursos que não estão de acordo com sua renda, ou seja, alunos de classe média inscritos em cursos como medicina também não foram aprovados. Além disso, no ano de 2000 foram permitidos até quatro fiadores para a composição da renda, de forma que os mais carentes também puderam ter acesso ao crédito.

No primeiro ano, 1999, foram concedidos 67.202 financiamentos acrescidos de outros 35.299, no exercício de 2000. Neste mesmo ano o repasse às IES somou R\$ 415.020.029,11 (quatrocentos e quinze milhões, vinte mil, vinte e nove reais e onze centavos) dos quais $\mathrm{R} \$ 310.585 .503,90$ (trezentos e dez milhões, quinhentos e oitenta e cinco mil, quinhentos e três reais e noventa centavos) foram recolhidos ao INSS. (Carazzai, 2001)

Apesar das críticas governamentais ao CREDUC, existem registros de que no ano 2000 foram concedidas 30.000 bolsas por meio deste programa. (IPEA, 2001) 
A criação de um Fundo do Ensino Superior que distribua recursos às IES constitui um projeto que está em tramitação no Congresso Nacional. No modelo proposto, o dinheiro ficaria destinado às IFES por dez anos. Após este período, a distribuição de recursos seria feita por indicadores de desempenho, e qualquer instituição, independente de sua dependência administrativa, participaria da divisão do bolo. Universidades de excelência que recebem parcos recursos federais, como as estaduais paulistas ou algumas católicas, passariam a ser contempladas.

De acordo com Amaral (2000), o orçamento das IFES já seria insuficiente para ampliação de vagas e vem sofrendo redução, percentualmente em relação ao Produto Interno Bruto e às Despesas Correntes da União, ao longo da década de 1990. Assim, a divisão de escassos recursos acentuaria definitivamente a crise de financiamento presenciada.

Muitas vezes são apontadas semelhanças entre o projeto apregoado pelo Banco Mundial e o do governo federal. De acordo com Dias Sobrinho (1999), os pontos principais da organização internacional para o Ensino Superior seriam os seguintes:

- estimular a competição entre as instituições;

- ampliar o setor privado;

- as instituições públicas devem procurar formas diversas de financiamento;

- o Estado só deve financiar de acordo com a produtividade;

- o Estado só deve se relacionar com a universidade para melhorar sua qualidade acadêmica e institucional.

Ainda como justificativa para a retirada do Estado do financiamento direto do Ensino Superior estaria a necessidade de reforçar a educação básica, colocando em concorrência por recursos esses dois níveis de ensino.

Para o Banco Mundial, o custo do Ensino Superior, bem como os gastos com a assistência estudantil, poderiam ser repassados aos estudantes através de empréstimos bancários ou bolsas restituíveis. Isto seria razoável porque os alunos são, em sua maioria, provenientes das camadas com maior poder econômico (em estudo que contempla diversos países, inclusos vários da América Latina). (Banco Mundial, 1996, p.71:74-119:123) 


\subsection{A gratuidade no Ensino Superior}

No Brasil, apesar de já existirem projetos de emenda constitucional que reformam o inciso IV do artigo 206, que estabelece a "gratuidade do ensino público em estabelecimentos oficiais", este não é o ponto principal da reforma. Mas, com a constante diminuição do orçamento público universitário e a proposta de que este dinheiro ainda contemple outras instituições que não as federais, a gratuidade deve sofrer um questionamento maior com o passar dos anos.

Paulo Renato Souza coloca a discussão da gratuidade como inevitável: "Queiramos ou não, acho que [a cobrança de mensalidades ou anuidade] estará na agenda dos próximos anos.”. (Weber, 25 ago. 1998, p. A9)

$\mathrm{Na}$ defesa do fim da gratuidade, foi escalado também o Prêmio Nobel de Economia Gary Becker, que critica os gastos com Ensino Superior no Brasil:

É um erro. Os que chegam na universidade são pessoas ricas ou de classe média, raramente são pobres. E os que saem ganharão salários muito superiores à média porque terão boa formação. Vocês estão financiando as pessoas erradas.

O governo deveria tentar estimular um acesso mais equilibrado nas universidades e, para os que não podem pagar, conceder empréstimos com prazo longo de pagamento. (Lahóz, 5 maio 1996, p.1-13)

Um dos principais argumentos pelo fim da gratuidade está centrado no perfil do aluno. Marilene Felinto, articulista de um grande jornal paulista, traduz bem este ponto de vista:

Ora, se o pai do estudante de medicina pôde pagar quase $\mathrm{R} \$ 1.000$ por mês para que seu filho se formasse nos renomados colégios de ensino médio de São Paulo, por que não continuar pagando isto na USP? Por que os quase dez anos de estudos de seu filho têm que ficar por nossa conta? (Felinto, 19 dez. 2000, p.C2)

Para Florestan Fernandes, argumentar a cobrança de mensalidades baseada no fim dos privilégios de alguns é uma discussão reducionista, bem como a simples aplicação de modelos de financiamento existentes nos países capitalistas avançados. Nestes países a iniciativa privada teve condições de produzir riquezas suficientes para financiar o Ensino Superior, enquanto no Brasil 
A única agência em condições de captar, na coletividade, recursos materiais e humanos em certa escala e de aplicá-los com certa preferência ao desenvolvimento educacional e cultural foi o Estado. Por isso, da intervenção estatal partiram as influências verdadeiramente decisivas, que criaram o grosso das oportunidades educacionais. A iniciativa privada confinou-se, em regra, às oportunidades educacionais que podiam ser facilmente comercializáveis, operando por conseguinte com o ensino destinado aos estratos sociais mas ricos e exclusivistas. (Fernandes, 1975, p.141)

$\mathrm{Na}$ visão do sociólogo, assim que os estratos sociais altos e médios passam a ter condições de financiar seu próprio ensino, descartam a gratuidade, aderindo a um modelo de sociedade competitiva em que os custos da obtenção de status social passam a ser de ordem privada. Isto elimina da competição os que não podem arcar com os custos, consolidando as posições de classe. A expansão do ensino superior público associada à gratuidade poderia efetivamente proporcionar mobilidade social e vertical.

O principal discurso pelo fim da gratuidade se assenta na idéia, presente no senso comum, de que o aluno rico dirige-se aos cursos públicos, e ao pobre fica reservado o particular. Porém esta colocação generalizadora não corresponde inteiramente à realidade quando observadas mais cuidadosamente as características dos ingressantes.

\subsection{O perfil dos candidatos e ingressantes.}

As características dos ingressantes variam em função de diversos fatores. Alguns elementos mostram-se recorrentes nesta discussão, como particularidades relacionadas ao curso, origem escolar anterior do estudante, renda e escolaridade dos pais.

Não se pretende aqui esgotar todas as possibilidades sobre cada um dos elementos que influem no acesso, mas realizar uma pequena discussão sobre eles na atualidade, em especial no que tange ao ingresso na USP.

Um indicador muito utilizado é o perfil sócio-econômico elevado; normalmente ele pode ser observado através da dependência administrativa da escola média. Em estudo realizado por Castro (1968), com os calouros de 1965, fica claro que este nem sempre foi um indicador relevante; a maioria dos estudantes pesquisados tinha cursado 
ensino médio particular (41,42\%); entretanto, em alguns locais - que podem ser considerados de "elite" - constatou-se boa presença de alunos da rede pública. $\mathrm{Na}$ USP, no curso de Medicina, cerca de 44,44\% encontravam-se nesta condição; já na Escola Politécnica este percentual foi de 48,57\%.

Naquela época, o Ensino Médio privado disputava a liderança pela oferta de vagas para o público de São Paulo, como vimos no início deste capítulo (Beisiegel, 1964). A despeito da expansão ocorrida, o acesso ao colegial ainda se constituía uma oportunidade para poucos; em geral, pessoas da classe média. Assim, tomar este dado como um exemplo de que naquela época havia uma maior democratização do Ensino Superior constitui uma incorreção.

No vestibular de 1977, organizado pela FUVEST, Dias e Martelli (1978) relatam que as chances de alunos oriundos de escolas públicas e particulares ingressarem nas carreiras de Medicina e ciências exatas ainda eram praticamente iguais, com ligeira vantagem para os oriundos da rede oficial.

Há também aqueles que afirmam, atualmente, haver plena igualdade entre os candidatos oriundos por rede de ensino, como Rose Neubauer, ex-secretária de educação de São Paulo:

Em 1998, 80\% dos jovens saídos do Ensino Médio haviam freqüentado escolas públicas, mas somente $40 \%$ dos vestibulandos das três universidades estaduais paulistas (USP, UNESP e UNICAMP) provinham da rede pública. Surpreendentemente, $34 \%$ do total de alunos aprovados e matriculados nessas universidades estudaram em escolas públicas. Eis uma lição: quando se inscrevem em vestibulares, as chances dos alunos da rede pública são semelhantes às dos alunos da privada. (Neubauer, 31 jan. 2000, p.3)

Porém um olhar mais atento às estatísticas do vestibular, em especial nas que dizem respeito aos cursos mais concorridos, pode contradizer este discurso. No vestibular da FUVEST do ano 2000, dos matriculados na carreira de Medicina, apenas $5,1 \%$ haviam cursado unicamente a escola pública, para um total de $18,7 \%$ de inscritos. Já na carreira de Engenharia e ciências exatas - que comporta os cursos oferecidos pela Escola Politécnica da USP - foram 34,9\% de inscritos no vestibular que cursaram a escola média oficial, para $14,4 \%$ de matriculados. No curso de Direito da USP havia $10,3 \%$ de ingressantes para $29,7 \%$ de candidatos com esse perfil. 
Fica evidente a importância da natureza administrativa da escola de Ensino Médio para ingresso nas carreiras mais concorridas no final da década de 1990, e como este elemento foi tornando-se preditor das possibilidades de ingresso nos cursos públicos mais concorridos.

Outro elemento considerado é o tipo de ensino, regular ou técnico profissionalizante. Este último normalmente não oferece uma melhor preparação, mas uma exceção é reconhecida: as escolas técnicas federais.

No vestibular da FUVEST, como se pode observar na Tabela 9, os estudantes oriundos das escolas técnicas federais representavam uma quantidade muito pequena dentre o volume de candidatos (menos de $2 \%$ ). Entretanto o resultado apresentado sempre foi positivo entre os matriculados, inclusive nas principais carreiras.

Tabela 9: Oriundos do ensino técnico federal - porcentagem destes entre o total de inscritos e matriculados em algumas carreiras do vestibular da FUVEST 2000.

\begin{tabular}{|l|c|c|}
\hline & Inscritos & Matriculados \\
\hline Total sem treineiros & $1,6 \%$ & $3,0 \%$ \\
\hline Medicina & $0,9 \%$ & $1,3 \%$ \\
\hline Direito & $1,5 \%$ & $3,3 \%$ \\
\hline Engenharia & $5,2 \%$ & $6,4 \%$ \\
\hline
\end{tabular}

Fonte: FUVEST 2000.

Paulo Renato Souza entende que o fato de boa parte dos formandos do ensino técnico federal dirigirem-se a cursos universitários pode constituir uma distorção das finalidades desta modalidade, que já é profissionalizante:

Temos um ensino técnico de boa qualidade. É onde se encontra o nosso melhor sistema de ensino de nível médio: nas escolas técnicas federais. Há uma seleção, nessas escolas, de 10 para 1 . Pega-se a nata dos alunos. [...] E mais de 50\% dos alunos das escolas técnicas e dos CEFETs vão para as universidades. Ou seja, estamos gastando verbas do ensino técnico para formar advogados. (Souza, 1998, p.22)

Se por um lado esse sistema atende a poucos alunos, e sua finalidade, que deveria ser a de profissionalização imediata, parece não estar sendo cumprida à risca, talvez esteja nas escolas técnicas federais, que são gratuitas e de boa qualidade, a 
possibilidade de alunos com menor renda ingressarem em carreiras mais concorridas. Mas esta afirmação dependeria também de um estudo sobre o perfil destes alunos, já que há uma seleção para o ingresso no curso técnico.

Outras especificidades ainda podem ser observadas com relação ao tipo de Ensino Médio. Cerca de 33,7\% dos inscritos em Pedagogia no ano de 2000 na USP declararam ter cursado o magistério, sendo que no bolo dos candidatos eles representavam apenas 2,3\%. Mas este fator acabou influindo negativamente no resultado, pois entre os matriculados apenas $26,9 \%$ declaram ter realizado esta opção de curso no Ensino Médio. É provável, neste caso, que o interesse pela mesma área de trabalho tenha direcionado grande contingente de candidatos com este perfil para o curso de Pedagogia.

Esse curso, e vários outros, como o de Letras, Enfermagem e Psicologia, são historicamente mais procurados pelo sexo feminino; o mesmo vale para algumas carreiras que são opções preferenciais dos homens.

Para Marília Carvalho (1999) a opção da mulher por determinados cursos reflete a escolha por áreas já consolidadas como suas no mercado de trabalho. Haveria também uma identificação com valores que a sociedade atribui ao gênero feminino em algumas profissões, como saúde pessoal, atenção ao desenvolvimento da criança e relações pessoais. O mesmo poderia ser aplicado ao campo masculino em profissões que estivessem associadas a valores como competitividade, racionalidade tecnológica, produtividade, dentre outros.

Dulce Whitaker acredita que o vestibular reproduza alguns preconceitos sexistas, já traduzindo dentro da universidade a divisão sexual do trabalho que ocorrerá a posteriori. Assim, caberia aos rapazes a procura por carreiras de uma suposta racionalidade a eles atribuída, e as mulheres ainda se arriscariam em carreiras de ciências exatas, mas naquelas de menor prestígio. (Whitaker, 1989)

Whitaker e Fiamengue também mostram que essa situação de escolha por gênero pode se alterar com o passar do tempo. Comparando resultados da UNESP de 1985 e 1986 com os de 1995 e 1996, verificam algumas alterações, em especial no curso de Medicina de Botucatu, que num primeiro momento tinha maior participação do sexo masculino, situação que se inverte nos resultados da década de 1990. (Whitaker \& Fiamengue, 1999) 
Mas os estereótipos do perfil de aluno por curso e, mais ainda, por universidade, não podem ser generalizados, pois ocultam diferenças importantes entre as diversas carreiras de uma mesma universidade.

No caso da USP, Maria da Graça Jacintho Setton aponta perfis diversificados entre os alunos da área de humanidades. Segundo a pesquisadora, é possível notar cursos, como os de Pedagogia e Biblioteconomia, nos quais a maior parte dos estudantes possui baixo capital social, cultural e econômico - e foram classificados por esta autora como "populares". No oposto encontrar-se-iam os de Direito e Administração - os "seletos". A definição desses três capitais foi procedida de acordo com indicadores como renda familiar, escolaridade dos pais, idade escolar, domínio de idiomas, dentre outros. (Setton, 1998)

Considerando que os cursos de Administração e Direito da USP, mesmo possuindo o período noturno, foram classificados como "seletos", pode-se pensar que a presença deste período não influa na composição do público. Assim, seria impróprio generalizar a diferenciação entre alunos por período, na qual os freqüentadores do noturno estariam numa condição sócio-econômica desfavorecida. Mas em outros estudos é possível notar que tal fator é importante na composição da clientela.

Na UFMG, onde na década de 1990 adotou-se uma política de expansão das vagas noturnas, observa-se uma diferenciação do alunado nos cursos que são oferecidos nos dois períodos:

A concorrência para os cursos oferecidos no turno da noite, quando comparada àquela dos cursos diurnos correspondentes, apresenta perfil sócio-econômico de estratos menos favorecidos. [...] As diferenças são expressivas, podendo-se afirmar que, pelo menos no caso da UFMG, mesmo sem conhecer a informação correspondente para o conjunto dos alunos da universidade, a abertura de cursos noturnos está contribuindo para democratizar o acesso ao ensino superior público. (Peixoto \& Braga, 2000)

Num estudo que procurou abordar alunos trabalhadores de uma escola particular noturna no Município de São Paulo no ano de 1984, Marília Spósito e outros encontram um determinado perfil de estudante: 
Os resultados de nossa pesquisa revelam que a escola superior noturna, de caráter privado, é freqüentada por um tipo de trabalhador específico: aquele localizado, em relação a seu vínculo produtivo, no setor terciário, trabalhando principalmente como auxiliar de escritório, secretário, bancário, professor, vendedor etc. em empresas multinacionais, estatais ou ainda, em menor número, no serviço público. (Spósito et alli, 1989, p.19)

Lúcia Teixeira Furlani, comparando vários trabalhos que estudam o perfil do aluno noturno em $A$ claridade da noite (1998), mostra que há grandes diferenciações entre estudantes de períodos distintos, embora seja o curso superior noturno aquele com melhores condições de abrigar o "trabalhador-estudante"10. A pesquisa de Furlani foi realizada com alunos residentes em Santos que estudaram no ensino superior noturno particular:

Em relação às demais pesquisas, esta possibilita ver que o noturno possui recortes internos: as formas de manutenção dos estudantes se diferenciam de acordo com o curso freqüentado; os mais concorridos atraem também pessoas de maior nível social e com uma trajetória escolar considerada mais "virtuosa", enquanto os menos disputados concentram, em geral, os que se encontram na situação inversa. Preconceitos e generalizações que cercam os alunos do noturno devem ser derrubados e encarados com cuidado.

Neste sentido desfazem-se os mitos de terem os alunos do noturno mais idade, uma trajetória escolar desprivilegiada, serem casados e com filhos. [...] porém as salas de aula noturna recebem também pessoas com essas características em maior quantidade, geralmente, em cursos mais desvalorizados socialmente em relação a outros. (Furlani, 1998, p.159)

O aluno do noturno tende a ter condição econômica menos privilegiada que o do diurno, mas, como vimos na USP e em alguns cursos pesquisados por Furlani, nos mais concorridos as vagas podem também ser preenchidas por alunos de um estrato de renda superior.

A despeito do perfil do concluinte dos cursos mais concorridos, faz-se importante observar os questionários sócio-econômicos do Exame Nacional de Cursos do ano 2000. Uma das questões fazia menção direta à renda familiar: "7. Em qual das faixas abaixo você calcula estar a soma da renda mensal dos membros da sua família

\footnotetext{
${ }^{10}$ Esta categoria engloba aqueles que possuem como vínculo principal o trabalho e como secundário o estudo, na iminência do abandono de uma das duas atividades, o estudo seria o sacrificado.
} 
que moram em sua casa? A - Até R\$ 453,00; B - De R\$ 454,00 a R\$ 1.510.00; C - De R\$ 1.511,00 a R\$ 3.020,00; D - De R\$ 3.021,00 a R\$ 7.550,00 e E - Mais de R\$ 7.550,00.’.

Ao se compararem os resultados dessa questão aplicada entre os diplomados das redes estaduais e federais e os da rede particular nos cursos de Medicina, Administração e Direito, percebe-se que não há grandes diferenças sócio-econômicas entre os formandos de acordo com a dependência administrativa e, ao contrário do esperado, os alunos da rede particular apresentam renda superior nos cursos de Administração e Medicina, enquanto no de Direito a situação se inverte. Mas são os cursos públicos de Direito que formam uma maior porcentagem de pessoas com nível inferior de renda, com a rede privada formando uma maioria na renda intermediária (veja Anexo 1).

Esse nivelamento pode ser fruto da dificuldade encontrada pelos alunos da rede particular no pagamento de mensalidades, e conseqüente abandono de curso, com maiores chances de formação para aqueles com renda superior.

Se em alguns cursos das instituições oficiais, o alunado é mais seleto, no resultado final, é lá que parecem se formar um maior número de pessoas provenientes das classes populares. Isso confirmaria a afirmação de Florestan Fernandes de que o sistema público e gratuito seria o ideal para proporcionar o nível superior à maior parte da população, sendo necessária apenas a expansão do setor.

Outro elemento comum nas análises sobre a predição de ingresso no Ensino Superior é a importância da escolaridade dos pais e do ambiente familiar para a ascensão na escala educacional. Tal importância foi abordada nos estudos de Pierre Bourdieu e utilizada para interpretar os resultados do vestibular brasileiro por Dulce Whitaker em A seleção dos privilegiados (1981). O auxílio da família aconteceria menos através de ações concretas - como eventual ajuda nos trabalhos escolares -, mas pela educação informal, com a inserção da criança num ambiente em que ela desde cedo aprenderia com os pais o domínio da norma culta, conhecimentos transmitidos informalmente através do contato com jornais e revistas, ampliação de vocabulário, assimilação de uma determinada sintaxe própria do ambiente escolar, dentre outras possibilidades. 
No vestibular da FUVEST, a maior escolaridade dos pais como indicador de sucesso pode ser observada na Tabela 10.

Tabela 10: Grau de instrução mais alto obtido pelos pais e mães dos inscritos e matriculados segundo alternativas do questionário da FUVEST 2000.

\begin{tabular}{|l|c|c||c|c|}
\hline \multirow{2}{*}{} & \multicolumn{2}{|c|}{ Escolaridade Pai } & \multicolumn{2}{c|}{ Escolaridade Mãe } \\
\cline { 2 - 5 } & Inscritos & Matriculados & Inscritos & Matriculados \\
\hline $\begin{array}{l}\text { Não freqüentou a escola ou tem } \\
\text { o primeiro grau incompleto }\end{array}$ & $8,3 \%$ & $4,2 \%$ & $7,5 \%$ & $3,7 \%$ \\
\hline Primário completo & $8,7 \%$ & $5,5 \%$ & $9,0 \%$ & $6,4 \%$ \\
\hline Ginasial (5 $5^{\text {a }} 8^{2}$ série) incompleto & $6,0 \%$ & $3,6 \%$ & $6,6 \%$ & $3,5 \%$ \\
\hline Ginasial completo & $6,1 \%$ & $3,6 \%$ & $7,4 \%$ & $5,1 \%$ \\
\hline Colegial (2 $^{\circ}$ grau) incompleto & $4,6 \%$ & $3,2 \%$ & $6,1 \%$ & $4,6 \%$ \\
\hline Colegial (2 ${ }^{\circ}$ grau) completo & $16,1 \%$ & $13,7 \%$ & $21,3 \%$ & $18,6 \%$ \\
\hline Universitário incompleto & $9,0 \%$ & $9,3 \%$ & $8,2 \%$ & $8,5 \%$ \\
\hline Universitário completo & $35,9 \%$ & $47,9 \%$ & $30,8 \%$ & $43,8 \%$ \\
\hline Mestrado ou doutorado & $5,4 \%$ & $9,0 \%$ & $3,1 \%$ & $5,4 \%$ \\
\hline
\end{tabular}

Fonte: FUVEST 2000.

É possível observar que aqueles candidatos cujo pai ou mãe superou o Ensino Médio, e principalmente quando possuidores de mestrado ou doutorado, são melhor representados no grupo de matriculados; enquanto a porcentagem dos candidatos com outro perfil sempre diminui após o exame.

Dulce Whitaker relata que o acesso aos níveis mais altos da educação ainda é recente na história brasileira. Sua expansão ocorreu principalmente nas décadas de 1960/70; logo, a escolaridade dos pais talvez não fosse um aspecto relevante num passado recente. Ainda hoje, apesar de já se constituir um preditor importante de sucesso, aproximadamente um terço dos pais e quarenta por cento das mães dos ingressantes não tiveram qualquer experiência universitária, de acordo com os dados da FUVEST 2000, revelando que vários estudantes que possuem pais com baixa escolaridade ainda conseguem atingir o Ensino Superior. Este seria mais um efeito da democratização do ensino nos mais diversos níveis.

Outro elemento presente nos estudos que abordam a desigualdade no acesso ao Ensino Superior é a questão da cor/raça do estudante. Florestan Fernandes, utilizando- 
se de informações contidas no Censo de 1950, já apontava para essa questão (Fernandes, 1975).

A desigualdade por cor na educação já é perceptível nas primeiras etapas do sistema educacional brasileiro, mas é no nível superior que ela se acentua. Sampaio, Limongi e Torres, ao observarem as estatísticas educacionais brasileiras da década de 1990, concluem:

Com efeito, o fato de ser jovem negro ou pardo parece implicar um nível mais baixo de escolaridade, independentemente do nível de renda familiar do jovem. Além disso, a diferença parece ser mais acentuada nos níveis de renda mais elevados do que nos mais baixos. Esses resultados são importantes porque indicam de forma muito contundente que a questão da cor é um dos aspectos constitutivos do fenômeno da desigualdade no sistema educacional brasileiro. (Sampaio, Limongi \& Torres, 2000, p.17)

O difícil é isolar essa característica de outras, como renda e nível educacional familiar, e saber qual o seu real peso na desigualdade. Sampaio, Limongi e Torres abordam o tema, mas não fazem nenhuma afirmação mais incisiva:

Em suma, os dados indicam que as variáveis escolaridade dos pais, renda familiar e cor afetam a distribuição dos jovens nos grupos de anos de escolaridade. [...] a variável cor parece ter um peso menor do que as variáveis renda familiar e escolaridade materna no quadro de possibilidades de o jovem atingir níveis mais elevados de escolaridade. (Sampaio, Limongi \& Torres, 2000, p.24)

Um dos elementos que sempre dificultou a discussão do tema foi a ausência de dados mais precisos sobre a composição do público universitário com base na cor. No questionário sócio-econômico do vestibular da FUVEST 2000, foi incluída uma questão que abordava o assunto. Nela pedia-se para o candidato definir a si mesmo com relação à sua cor/raça, baseado nos termos do IBGE: branca, preta, parda, amarela e indígena.

Uma análise das respostas do questionário foi produzida por Antônio Sérgio Guimarães, Paula Cristina da Silva e Reginaldo Prandi. Eles argumentam que a cor tem uma influência no resultado que não pode ser explicada por elementos sócioeconômicos: 
Entre os candidatos oriundos de famílias de nível sócio-econômico A, por exemplo, a taxa de aprovação dos 'amarelos' é 13,1\%, dos 'pardos' 8,5\%, dos 'brancos' $8,1 \%$ e dos 'pretos' 5,6\%. É interessante que os 'amarelos' oriundos de famílias de nível sócio-econômico $\mathrm{C}$ têm taxa de aprovação maior $(8,5 \%)$ do que a dos 'brancos', e igual a dos 'pardos' de nível A. (Guimarães, Silva \& Prandi, 2000)

Eles constatam também que há mecanismos anteriores à seleção que influem no perfil dos candidatos.

No conjunto dos candidatos ao vestibular, observa-se a seguinte distribuição em termos de cor: $81,1 \%$ dos estudantes classificaram-se como 'brancos', $2,1 \%$ como 'pretos', 7,7\% como 'pardos', $8,4 \%$ como 'amarelos' e $0,6 \%$ como 'indígenas'.

Esta distribuição chama a atenção se contrastada com a composição da população do Estado de São Paulo, segundo a cor: $73,5 \%$ de 'brancos', 4,4\% de 'pretos', $20,9 \%$ de 'pardos' e $1,1 \%$ de 'amarelos'. Destaca-se que, especialmente no caso dos 'pardos' e dos 'amarelos' há uma grande distância entre a proporção presente na população em geral e a proporção que presta o concurso vestibular, o que já indica a existência de mecanismos anteriores a ele, que fazem com que alguns grupos sejam muito mais estimulados do que outros a tentar ingressar no Ensino Superior, pelo menos nestas universidades. Considerando a relação da variável cor com o sucesso ou fracasso no vestibular, observa-se que a proporção de 'brancos' aprovados é, praticamente, igual a de reprovados; enquanto que a proporção de 'pretos' e, principalmente, de 'pardos' aprovados é menor do que a proporção de reprovados; relação que se inverte no caso dos 'amarelos', que estão em proporção bem maior entre os aprovados. (Guimarães, Silva \& Prandi, 2000)

A constatação desses autores sobre a existência de mecanismos anteriores à seleção que favorecem determinados grupos a tentar ingressar na universidade, é um dos elementos definidores do perfil do ingressante e não se restringe apenas à questão da cor da pele.

A auto-exclusão de alguns candidatos antes mesmo do processo seletivo é entendida por Bourdieu e Passeron em A reprodução da seguinte forma:

Mesmo quando aparece imposto pela força da 'vocação' ou pela comprovação da inaptidão, todo ato de escolha singular pelo qual um indivíduo se exclui do acesso a um ciclo de ensino ou se resigna a um tipo desvalorizado de estudos subentende o conjunto das relações objetivas (que preexistam a essa escolha e que sobreviverão à mesma) entre sua classe social e o sistema de ensino, pois um futuro escolar só é mais ou menos provável para um indivíduo determinado na medida em que constitui o futuro objetivo e coletivo de sua classe ou de sua categoria. (Bourdieu \& Passeron, 1975, p.165) 
Assim, antes mesmo da seleção, é possível observar as diferenças de perfil de candidatos para determinadas carreiras e universidades como uma adequação feita pelo vestibulando às suas reais probabilidades de ingresso.

Outro elemento que pode contribuir para afastar os alunos de menor renda dos cursos mais concorridos é o discurso que coloca as principais universidades públicas como um local reservado a pessoas mais abastadas, os chamados "filhinhos de papai". Se esse discurso possui sua parcela de verdade, como se viu anteriormente, há também alunos de baixa renda em todos os tipos de curso, e estão nas universidades públicas suas maiores chances de diplomação, como mostraram os dados sócio-econômicos do Provão.

\subsection{Igualdade no acesso e reserva de vagas}

Um dos principais argumentos contra a gratuidade, como vimos anteriormente, é a desigualdade no acesso aos cursos superiores públicos. Uma medida um tanto quanto polêmica, que trata diretamente desta questão, encontra-se em pauta: a reserva de vagas.

A reserva de vagas pode ser classificada como pertencente ao rol de "ações afirmativas", que Sabrina Moehlecke, em Propostas de Ações Afirmativas no Brasil: o acesso da população negra ao Ensino Superior, definiu como:

[...] políticas compensatórias, fundamentadas no princípio de igualdade que sustenta o tratamento desigual aos desiguais, usualmente aplicadas de acordo com critérios sócio-econômicos; mais especificamente podem ser políticas compensatórias voltadas para determinado grupo, definido a partir de características adscritas como raça ou gênero; ou políticas de diversidade, que reivindicam não uma igualdade de bens materiais, mas culturais, numa exigência de reconhecimento de identidades particulares. (Moehlecke, 2000, p.9)

Ela é um modelo que teria se difundido no Brasil através da reserva de vagas para a candidatura de parlamentares femininas. Moehlecke cita outras possíveis formas de ações afirmativas, como os próprios cursinhos pré-vestibulares voltados predominantemente para o atendimento do público negro. 
No âmbito federal, o projeto de reserva de vagas do senador Antero Paes de Barros, do PSDB-MT, foi o que teve maior repercussão, suscitando projetos regionais, como o aprovado pela Assembléia Estadual do Rio de Janeiro, que trata da reserva nas universidades mantidas por aquele Estado. Ambos os projetos destinam 50\% das vagas para estudantes provenientes da escola básica pública, sendo que o federal já foi aprovado por unanimidade no plenário do Senado e seguiu para a Câmara Federal, enquanto o fluminense já foi sancionado pelo governador.

O Projeto de Lei ${ }^{0}$. 298/99, aprovado no Senado, foi o seguinte:

Art. $1^{\circ}$ Ficam as universidades públicas obrigadas a reservar, anualmente, cinqüenta por cento de suas vagas para alunos que tenham cursado integralmente os ensinos fundamental e médio em escola pública.

Parágrafo único - $\mathrm{O}$ direito à vaga pressupõe aprovação no processo seletivo adotado pela universidade e classificação dentro do percentual acima estabelecido.

Art. $2^{\circ} \mathrm{O}$ Poder Executivo, por meio de seu órgão competente, regulamentará esta Lei no prazo de noventa dias, contados a partir de sua vigência.

Art. $3^{\circ}$ Esta Lei entrará em vigor na data de sua publicação.

Várias foram as polêmicas suscitadas pela aprovação. Uma inicial abordou a constitucionalidade do projeto, aliás, única ressalva feita por alguns senadores no momento da aprovação.

O projeto seria inconstitucional por ferir a autonomia universitária, o princípio da igualdade no acesso e o acesso segundo a capacidade de cada um aos níveis mais elevados do ensino. A defesa da constitucionalidade foi feita sob o preceito de que a autonomia universitária é limitada e regida por leis maiores; o atual sistema não garante a igualdade no acesso; e muitos que seriam capazes de cursar acabariam excluídos, por serem restritas as vagas das universidades públicas.

Uma segunda polêmica aborda os temas relacionados ao fim do mérito acadêmico na seleção. O problema seria que este mecanismo é definidor do mundo universitário, ou seja, a organização desse nível de ensino é feita sobre ele. O exame de ingresso seria o indicador de mérito acadêmico, devendo prevalecer acima de qualquer outro critério. Bobbio, Mateucci e Pasquino problematizam a questão: 
As posições favoráveis à Meritocracia estão ligadas a um igualitarismo formal que advoga o reconhecimento dos méritos de cada um, enquanto muitas das posições contrárias se baseiam num igualitarismo nivelador que pretende negar as diferenças de cada um.

E, numa posição contrária ao mérito, tem-se que:

[...] a seleção escolar meritocrática seria impossível de ser realizada e a função do sistema de ensino seria exatamente a de fazer com que pareçam naturais as diferenças de capacidade, quando, na realidade, essas diferenças decorrem da diferenciação social preexistente. (Bobbio, Mateucci \& Pasquino, 1986:747748)

O Senador Antero Paes de Barros aborda o problema em suas justificativas. Para ele o projeto não abandonaria o mérito:

Nas condições aqui propostas, a questão do mérito acadêmico seria preservada uma vez que os candidatos oriundos de escolas públicas seriam igualmente submetidos ao processo de seleção adotado pela instituição de ensino superior, e ingressariam apenas aqueles classificados para o número de vagas reservadas. (PL 298/99)

Outro argumento contrário ao projeto advoga que o essencial no combate à desigualdade seria a melhora da educação básica pública, pois medidas como essa apenas isentariam o governo de investir adequadamente na educação e estigmatizariam ainda mais a rede pública. Porém, o efeito negativo de esperar a melhora da educação é que, enquanto isso não ocorre e as perspectivas não são animadoras, mantém-se a atual desigualdade; a estigmatização não ocorreria, mas o aluno continuaria sem possibilidade de estudo.

O projeto ainda prejudicaria os alunos da rede particular que não puderam mudar de escola a tempo e vários deles- que seriam aprovados no modelo anterior mas que foram excluídos pela reserva -, poderiam requerer seu ingresso por medida judicial, criando um caos na porta das universidades. A argumentação contrária definiria a situação atual como um caos para o aluno da rede pública, excluído das principais carreiras. Seria difícil defender um sistema que beneficia uma minoria em prol da discriminação da maior parte dos alunos. A reserva ainda corrigiria uma 
distorção do atual sistema, diminuindo a auto-exclusão dos vestibulandos ao estimular a inscrição nas diversas carreiras daqueles que antes imaginavam não ter chances de matrícula.

Rogério Cezar de Cerqueira Leite levanta ainda outra questão. Ele ressalta que a solução que aponta para a implementação de cursos de capacitação internos apenas demonstra que estes alunos não possuem condições de cursar normalmente. Estes cursos criariam uma universidade "cindida" em duas; uma para os "afortunados" e outra para os "desafortunados". (Leite, 13 dez. 1999, p.3)

Ademais, a universidade teria de se adaptar para receber os novos alunos, trazendo sobrecarga aos professores universitários, que já não possuem as melhores condições de trabalho. O desvio de atividades de pesquisa para atender estudantes deficitários poderia gerar graves conseqüências, já que quase toda atividade de pesquisa concentra-se nas universidades públicas.

Outra crítica é que o projeto seria demagógico e paternalista. Isto se expressaria no trato simplista que se dá à questão; não se resolve o problema da desigualdade por curso, uma vez que a reserva é para a universidade. José Atílio Vanin, que coordenou por vários anos o vestibular da FUVEST, chegou a afirmar que se poderia ter $100 \%$ de alunos da rede particular no curso de Medicina e 100\% de alunos da rede pública em cursos de pouca demanda, desde que o percentual final da USP respeitasse os $50 \%$ de alunos oriundos de escola pública.

O Núcleo Avançado de Estudos da Graduação da USP - NAEG - realizou uma simulação do impacto que a reserva de vagas para alunos da rede pública teria na USP; com base nos resultados da FUVEST em 2001, chega à conclusão que 27,6\% dos matriculados seriam excluídos com a adoção dessa medida naquele ano.

A eventual adoção de um sistema de quotas produz um impacto bastante significativo. Esse impacto ao nosso ver é negativo pois acreditamos que o preparo de um possível candidato beneficiado não estaria dentro de padrões desejáveis para uma universidade de excelência.

$(\ldots)$

A presença de candidatos em carreiras concorridas com algumas disciplinas com nota zero no vestibular é uma possibilidade real. Mesmo naquelas disciplinas fundamentais para a carreira. (NAEG, 2001a) 
Se a prova de vestibular deve ser a mesma para todos os candidatos, que outros mecanismos garantirão a permanência do aluno após o ingresso? Por que este percentual e não um outro qualquer? Por que os alunos beneficiados têm de ter cursado toda a educação básica em instituições públicas e não apenas o Ensino Médio? Esses são pontos que ficam em aberto.

A reserva de vagas, entretanto, não é apenas uma solução empregada para a resolução da desigualdade por escola média cursada. No Rio de Janeiro já existe legislação que assegura um percentual de vagas para a população negra. O projeto, aprovado pela Assembléia Legislativa do Rio de Janeiro no ano de 2001, é o seguinte:

Art $1^{\circ}$ - Fica estabelecida a cota mínima de $40 \%$ (quarenta por cento) para as populações negra e parda no preenchimento das vagas relativas aos cursos de graduação em todas as instituições públicas de educação superior - universidades - do Estado do Rio de Janeiro

Art $2^{\circ}$ - O Poder Executivo regulamentará a presente Lei no prazo de 30 (trinta) dias de sua publicação.

Art. $3^{\circ}$ - Esta Lei entrará em vigor na data de sua publicação, revogadas as disposições em contrário.

O percentual foi definido de acordo com a população negra e parda residente naquele Estado segundo informações fornecidas pelo IBGE. Neste caso, a principal polêmica seria a de como classificar cada vestibulando; se este procederia a uma autoclassificação ou se haveria uma comissão para realizar tal tarefa. Até foi mencionada a possibilidade do envolvimento de especialistas em Biologia e Genética. Provavelmente, visto que os números do IBGE são coletados com base na autoclassificação, deve ser este o critério adotado.

Outro problema seria o de combinar esta lei com a outra, já aprovada no Estado do Rio de Janeiro, que garante a reserva de 50\% das vagas para alunos da rede pública. Tal tarefa ficou sob a responsabilidade da Secretaria de Ciência e Tecnologia, à qual estão subordinadas as universidades públicas estaduais; o então secretário Wanderley de Souza definiu que as cotas sejam sobrepostas. Assim, para um total de 100 vagas, ingressam os 50 melhores colocados da rede pública, verifica-se a quantidade de negros ou pardos, e, caso sejam em número inferior a 40, completa-se com pessoas 
oriundas da rede particular, até ser alcançado o percentual estipulado de negros e pardos. Desta forma, pretende-se atender às duas leis. (Escóssia, 14 nov. 2001)

Assim, espera-se que o estudante pobre ingresse no Ensino Superior através da reserva, com igualdade no acesso, espera-se que isto resulte também em melhores oportunidades de trabalho e mobilidade social para esta população.

\subsection{Ensino Superior, renda e trabalho.}

A expansão do Ensino Superior nas décadas de 1960/1970 trouxe um maior número de formados, ocasionando oferta de diplomados em quase todas as áreas. Porém, como mostra Reginaldo Prandi, em Os favoritos degradados (1982), nos anos 1980 o desemprego ainda não fazia parte da vida dos formados, ele era substituído por um desvio da função principal que o diploma prometia:

O desemprego, entretanto, não chega a ser tão ameaçador. Agrônomos dão ótimos vendedores de fertilizantes. Excelentes os engenheiros químicos na distribuição de tintas. Muito bom o desempenho dos bancários economistas, talvez melhor os matemáticos. Arquitetos fotografam muito bem. Analistas de sistemas operam eficientemente, com uma mão na frente e outra atrás, qualquer computador de quarta geração. A queda nos padrões de qualidade de vida e todo o conjunto de insatisfações e frustrações geradas pelo sentimento de distanciamento entre o que a escola ensina (quando ensina), como promessa, e as atividades que na vida do trabalho rotineiramente realiza são fenômenos já experimentados pela classe trabalhadora há muito tempo: a proletarização e a alienação do trabalho. (Prandi, 1982:75)

Em resultado semelhante, Marília Spósito e outros constatam que a matrícula no ensino superior noturno para o trabalhador-estudante também proporcionava uma melhor ocupação:

[...] ao compararmos as ocupações exercidas na época em que começaram a trabalhar e as ocupações atuais é possível conferir que a freqüência à escola entre outros fatores possibilitou certa "melhora" na escala ocupacional para aqueles que nela ocupavam posições menos valorizadas. É evidente que este papel positivo, atribuído à escolaridade apareceu em quase todos os depoimentos. (Spósito et alli, 1989:60) 
A Tabela 11 reproduz os dados colhidos na Pesquisa Nacional por Amostra de Domicílios de 1998. Nela é possível observar possíveis correlações entre escolaridade e nível de renda.

Tabela 11: Pessoas de 10 anos ou mais de idade, ocupadas na semana de referência, por grupos de anos de estudo segundo as classes de rendimento mensal de todos os trabalhos.

\begin{tabular}{|l|r|r|r|r|r|r|r|}
\hline & $\begin{array}{r}\text { Até 3 anos } \\
\text { de }\end{array}$ & $\begin{array}{r}4 \text { a } 7 \text { anos } \\
\text { de } \\
\text { escolaridade }\end{array}$ & $\begin{array}{r}8 \text { a } 10 \text { anos } \\
\text { escolaridade }\end{array}$ & $\begin{array}{r}11 \text { a } 14 \text { anos } \\
\text { escolaridade }\end{array}$ & $\begin{array}{r}15 \text { anos ou } \\
\text { mais de } \\
\text { escolaridade }\end{array}$ & $\begin{array}{r}\text { sem } \\
\text { escolaridade }\end{array}$ & $\begin{array}{r}\text { TOTAL } \\
\text { determinado e } \\
\text { não }\end{array}$ \\
\hline Até 3 S.M. & 13.451 .251 & 13.269 .897 & 5.824 .728 & 4.759 .546 & 360.274 & 148.575 & 37.814 .271 \\
\hline $\begin{array}{l}\text { Mais de 3 a 5 } \\
\text { S.M. }\end{array}$ & 1.431 .889 & 3.143 .097 & 1.984 .000 & 2.811 .901 & 526.428 & 26.792 & 9.924 .107 \\
\hline $\begin{array}{l}\text { Mais de 5 a } \\
\text { 10 S.M. }\end{array}$ & 452.333 & 1.411 .393 & 1.251 .991 & 2.657 .073 & 1.254 .405 & 12.437 & 7.039 .632 \\
\hline $\begin{array}{l}\text { Mais de 10 a } \\
\text { 20 S.M. }\end{array}$ & 121.842 & 352.014 & 308.692 & 1.094 .121 & 1.235 .304 & 357 & 3.112 .330 \\
\hline $\begin{array}{l}\text { Mais de 20 } \\
\text { S.M. }\end{array}$ & 37.157 & 94.153 & 86.825 & 356.177 & 1.025 .339 & 0 & 1.599 .651 \\
\hline $\begin{array}{l}\text { Sem } \\
\text { rendimento }\end{array}$ & 5.009 .209 & 3.196 .170 & 744.797 & 449.973 & 68.805 & 21.467 & 9.490 .421 \\
\hline $\begin{array}{l}\text { Sem } \\
\text { declaração }\end{array}$ & 285.748 & 221.129 & 136.132 & 204.148 & 134.260 & 1.284 & 982.701 \\
\hline \multicolumn{1}{|c|}{ TOTAL } & 20.789 .429 & 21.687 .853 & 10.337 .165 & 12.332 .939 & 4.604 .815 & 210.912 & 69.963 .113 \\
\hline
\end{tabular}

Fonte: IBGE, Pesquisa Nacional por Amostra de Domicílios 1998 (adaptado).

É possível reparar que as maiores rendas acabam ficando com as pessoas de maior escolaridade, $64,1 \%$ das pessoas que recebem mais de 20 salários mínimos possuem mais de 15 anos de estudo. No extremo oposto, dentre aqueles que recebem até 3 salários mínimos, 70,7\% têm menos de 7 anos de estudo.

Assim, é compreensível que a busca pelo Ensino Superior ainda traduza uma expectativa de melhora de renda e ocupação, que este seja mais um elemento que estimule a procura pelo nível superior por diversas camadas da população.

\subsection{Considerações finais sobre o capitulo}

Foi possível observar algumas similitudes entre o ocorrido no campo educacional nas décadas de 1960/1970 e os acontecimentos da década de 1990. A 
expansão dos ensinos médio e superior, o aumento da autorização de novos cursos no ensino superior privado e as alterações nos mecanismos de seleção universitária são alguns dos pontos comuns entre as duas épocas.

A expansão dos níveis de ensino, com uma maior oportunidade educacional para todos, parece se dar em "cascata"; à medida que a camada mais desfavorecida economicamente conquista o Ensino Médio, parte em busca do superior. A pressão popular, como definiu Beisiegel, tem sido definidora do crescimento dos diversos níveis de ensino.

A atual expansão do Ensino Superior ocorre novamente através da rede particular, desta vez acompanhada de uma avaliação, cujo principal foco é o diplomado. Este processo avaliativo procura estabelecer concorrência entre as diversas IES existentes, numa crença de que o mercado atuará como definidor de qualidade.

As IES públicas também sofrem um processo de reforma e, tal como em 1968, é possível observar soluções de empresas capitalistas sendo utilizadas na gestão do ensino, em especial a remuneração por produtividade, seja ela institucional ou pessoal (no caso dos docentes).

Pode-se perceber, por trás dessas reformas, um processo de adaptação por que as instituições têm de passar para atendimento da demanda. Um exemplo seria o incentivo à abertura de cursos noturnos públicos, mais adequados para o atendimento da população trabalhadora.

Apesar do incremento da matrícula, é possível observar que o atendimento ocorre de forma desigual. A seleção realizada leva alguns grupos a obter representação majoritária nas carreiras mais disputadas, enquanto outros, na sua maioria, ficam relegados a um Ensino Superior de baixa qualidade.

É nesse quadro que surgem e se proliferam os cursinhos pré-vestibulares alternativos, descritos no capítulo seguinte. Eles surgem como conseqüência de um período em que o estudante pobre, de forma coletiva, começa a obter o certificado de Ensino Médio e passa a sonhar com a etapa seguinte.

Assim, pretende-se, através da observação dos cursinhos pré-vestibulares alternativos, ver, num sistema em que o ensino pago predomina e em que as parcas vagas públicas acabam sendo ocupadas por alunos de classe média, quais são as 
estratégias desenvolvidas para viabilizar o sonho do diploma universitário para o estudante pobre, bem como a repercussão de suas ações no acesso ao Ensino Superior. 


\section{CAPÍTULO 2 - Os cursinhos alternativos no Município de São Paulo na década de 1990}

Neste capítulo foi reunido o material coletado sobre os diversos cursinhos alternativos, a metodologia utilizada para isso, e, por fim, foram realizadas algumas análises agregando os elementos que se destacaram.

\subsection{Cursinhos alternativos}

Muitos dos cursinhos encontrados sob o rótulo de "alternativos" são organizados pelo movimento estudantil uspiano; este tipo de atividade, entretanto, remonta a outras épocas.

Encontraram-se professores da USP que relatam ter estudado no cursinho organizado pelo Grêmio dos Alunos da Faculdade de Filosofia, Ciências e Letras da USP, ainda na década de 1950. Outros seriam o organizado pelo Departamento Acadêmico do Curso de Administração na Fundação Getúlio Vargas e o patrocinado pelo Grêmio dos Alunos da Escola Politécnica da USP, ambos com funcionamento anterior à década de 1970.

Na década de 1960 tem-se registro, nas palavras de Luiz Antônio Cunha, de atividade semelhante no Rio de Janeiro:

Na Faculdade Nacional de Filosofia da Universidade do Brasil, pelas mesmas razões [um inquérito promovido pela reitoria que buscava deter ações subversivas], foi fechado o curso pré-vestibular mantido pelo Diretório Acadêmico, extintos os cursos noturnos e eliminado o critério classificatório nos exames vestibulares. (Cunha, 1988, p.55)

O fenômeno do surgimento dos cursinhos alternativos é nacional. Em Florianópolis foi realizado o I Encontro de Experiências de Pré-Vestibulares Populares promovido pelo Grupo de Pesquisa Educação Popular, Saúde e Cidadania e pelo Centro de Evangelização e Documentação em Educação Popular, CEDEP; neste encontro, reuniram-se representantes de cursinhos de diversas regiões do país. 
Em matéria da revista Caros Amigos, ainda é possível notar a presença destes cursinhos em São Paulo, Recife, Vitória, Salvador, Campinas, Porto Alegre e Rio de Janeiro. Verifica-se, de imediato, a presença de organizações estudantis e do movimento negro como patrocinadores. (Amaral, fev. 2000, p.13-15)

$\mathrm{Na}$ Bahia, a Cooperativa Educacional Steve Biko foi o primeiro pré-vestibular vinculado ao movimento negro e estudantil, ainda no ano de 1992. Maria Durvalina Cerqueira Santos relatou esta experiência em Educação, cidadania e reconstrução de identidades: caso Cooperativa Steve Biko. (Santos, 1997)

Como objetivo da cooperativa esperava-se, além do fornecimento de um conhecimento específico do vestibular, a formação de uma consciência política e racial. Para isto foi incluída a disciplina de Cidadania e Consciência Negra, que procura informar sobre:

[...] civilização africana antes da colonização, o processo de colonização e escravidão no Brasil, os movimentos de resistência negra desde a colonização até a contemporaneidade, organizações negras, as entidades religiosas, os mecanismos de barragens da sociedade racista atual, a estética afro-brasileira, relações socais, políticas partidárias, políticas econômicas, relações de poder, as produções acadêmicas do negro pelo negro etc. (Santos, 1997, p.61)

Procurou-se trabalhar com alunos afrodescendentes que já tivessem experiência em entidades associativas para que pudessem enriquecer a formação política do grupo. Os instrutores eram preferencialmente afrodescendentes, esperando que isto contribuísse para a construção de uma identidade étnico-racial entre os participantes; os docentes foram avaliados quanto a conceitos e valores, pois têm influência sobre o imaginário cultural dos estudantes. A remuneração é feita por hora-aula, sem vínculo empregatício.

Como se verá adiante, esta experiência inspirou outros cursinhos prévestibulares com origem no movimento negro.

\subsection{Metodologia}

Para o mapeamento e caracterização dos cursinhos alternativos foram usadas diversas formas de coleta de dados, que incluíram: 
a) panfletos, folhetos explicativos e todo tipo de material produzido pelos cursinhos;

b) artigos de jornal;

c) visitas às sedes e núcleos;

d) entrevistas com coordenadores;

e) ações judiciais que visam modificar o atual sistema de ingresso nas universidades;

f) principais alterações na organização dos vestibulares, em especial da FUVEST, através de documentos produzidos por essa organização.

Neste percurso foram encontrados obstáculos, pois alguns cursinhos não possuíam sequer uma proposta sistematizada de atuação, muitas vezes devido ao início recente de suas atividades; outros, que funcionavam sob a forma de núcleos, não tinham um quadro organizado dos locais onde ocorriam as atividades, constando às vezes apenas telefone ou endereço de um coordenador que nem sempre foi possível contatar; outros, ainda, existiram apenas por curto período de tempo, e o trabalho se restringiu a conversas com antigos coordenadores. As dificuldades serão relatadas na descrição adiante sobre cada proposta encontrada.

Numa cidade tão extensa quanto São Paulo, a distância dificultou as visitas programadas, mas contribuiu para o conhecimento de algumas das dificuldades existentes. Optou-se por realizar um levantamento quantitativo dos cursinhos. Com isto, podem ter sido prejudicados aspectos relacionados a uma descrição mais detalhada das pessoas e motivações envolvidas, bem como o levantamento de temas das aulas de cidadania e o detalhamento de outros aspectos. Todavia, ganhou-se na exposição da pluralidade de projetos, dos diferentes apoios recebidos e das estratégias organizacionais.

A coleta de informações sobre cada cursinho iniciou-se no ano de 1999, como um trabalho realizado para obtenção de créditos-atividade. Na época foi construído um roteiro que procurava abarcar todos os aspectos dos cursinhos; este roteiro foi acrescido de itens relacionados à expansão das vagas ao longo dos anos e questões sobre a participação política nos movimentos reivindicatórios por ingresso no Ensino Superior. O roteiro utilizado encontra-se no Anexo 2. 
Evidentemente, a pesquisa de campo e o contato direto com os cursinhos revelaram outros elementos antes não imaginados, como a existência de várias formas de organização dentro de uma mesma proposta, por conta dos diversos núcleos.

\subsection{Caracterização dos diversos cursinhos}

Aqui são descritos os cursinhos alternativos encontrados no Município de São Paulo no período de 1991 a 2000.

\subsubsection{Educafro - Educação para Afrodescendentes e Carentes}

A Educafro é sem dúvida a mais complexa organização encontrada, isto porque é dividida em diversos núcleos que possuem relativa autonomia, e conta com uma direção vinculada à Igreja Católica através da Província Franciscana da Imaculada Conceição do Brasil.

Em 1993, no Estado do Rio de Janeiro, o atual diretor-executivo da Educafro, Frei David Raimundo dos Santos, fundou o primeiro cursinho para negros e carentes daquela região, projeto que proliferou rapidamente através da formação de diversos núcleos. $\mathrm{O}$ cursinho permanece em funcionamento, porém desvinculado da direção da Igreja Católica e com o nome de Pré-Vestibulares para Negros e Carentes - PVNC. A Educafro passou a existir no Rio de Janeiro com a atividade principal de concessão de bolsas de estudo em universidades particulares.

O diretor, Frei David, é uma pessoa polêmica dentro da Igreja, tendo sido afastado de duas dioceses. Na primeira ocorrência, ainda na época da ditadura militar, ele constava como comunista em uma lista do Serviço Nacional de Informações; na segunda, montou um encontro de religiosos negros na diocese do Rio de Janeiro. Após esse episódio, ele foi transferido para a diocese da Baixada Fluminense, onde iniciou o trabalho dos cursinhos. O frade organiza ainda missas baseadas em cultos africanos. Ele entende que a Igreja Católica não tem de reproduzir apenas o culto europeu, já que, originalmente, o culto deveria ser judaico, e como não é, pode mesclar outras culturas também. O criador da Educafro afirma querer que os estudantes se indignem com sua condição e passem a lutar por seus direitos. (FSP, 27 ago. 2000) 
O nome Educafro - Educação para Afrodescendentes e Carentes - foi pensado como uma forma de ajudar o negro a se assumir enquanto tal, e também como medida para afastar alunos de classe média que pudessem querer se inscrever no cursinho, garantindo que os alunos fossem predominantemente carentes e/ou afrodescendentes.

O objetivo da Educafro é garantir o acesso e a permanência do estudante negro e/ou carente no ensino universitário. Para isto a entidade também desenvolve uma série de ações, além do oferecimento do pré-vestibular.

Uma primeira ação seria garantir que o estudante pobre esteja isento da taxa do vestibular, que afugentaria parte dos candidatos desfavorecidos economicamente; uma segunda procura que a universidade pública atenda prioritariamente aqueles alunos com necessidades financeiras por meio da implementação da reserva de vagas públicas; e uma terceira visa garantir bolsas de estudo para os alunos que ingressaram no ensino particular e não possuem condições de arcar com seus custos. A entidade luta ainda pela cota de negros na universidade pública, dentre outras ações que são mais bem detalhadas no capítulo 3 .

A Educafro é dividia em núcleos que possuem grande autonomia. Pode-se dizer que inexiste fiscalização sobre suas atividades. Para a abertura de um núcleo são sugeridos vários passos:

1 PASSO: é ter um grupo de pessoas da localidade interessada nesta proposta educacional de ensino. Fazem algumas reuniões para refletirem sobre a proposta e definirem uma coordenação provisória para o trabalho. Na maioria das vezes esta proposta nasce de uma entidade popular. Exemplos: Pastoral do Negro, Associação de Moradores, ex-alunos dos pré, Pastoral da Juventude, grupo de amigos etc.

Sempre que possível uma pessoa de um dos pré organizados tem ido para ajudar e refletir a idéia, a partir de suas experiências no movimento.

Cada núcleo de Pré-Vestibular que está nascendo é totalmente autônomo, tem vida própria, coordenação própria etc. Todos se articulam através de reuniões mensais.

$\underline{2}$ PASSO: é refletir, escolher e conseguir o espaço onde a experiência irá funcionar: na sede da associação de moradores? Em uma Igreja Evangélica? No Sindicato? Numa Escola Municipal? Numa escola Particular? Num salão de Igreja Católica?

$\underline{3}$ PASSO: é visitar os professores que moram no bairro, apresentar a proposta e convidá-los para serem mais um voluntário no mutirão da educação alternativa, doando apenas uma hora de aula por semana, ministrando a matéria de sua 
aptidão. É entregue a cada professor o conteúdo programático, exigido pelo vestibular da USP, para aquela matéria. Cada professor segue o seu estilo de ministrar o conteúdo. Está se prevendo para o ano 2000 a oficialização de uma apostila em conjunto com outros prés populares.

4 PASSO: é eleger duas pessoas do núcleo para tomarem parte nas reuniões mensais da EDUCAFRO que acontecem todo último domingo do mês, às 14:00 horas, em lugar fixo, de fácil acesso. Neste último domingo acontece, às 9 horas, a reunião mensal de todos os estudantes universitários oriundos do projeto, bolsistas ou não. Todos os participantes desta experiência popular de educação (professores, alunos, coordenadores, solidários) são convidados a participar destes dois momentos fortes de cidadania. (Educafro, 1999(?)grifos do autor)

Os núcleos têm apenas de seguir algumas diretrizes gerais, como:

- oferecer aula de cultura e cidadania;

- ser auto-sustentável, com mensalidade do aluno em valor inferior a $10 \%$ do salário mínimo;

- ter professores voluntários que recebem somente uma ajuda de custo para transporte e alimentação no local;

- oferecer vagas preferencialmente para alunos negros e carentes e há mais tempo distantes de uma sala de aula;

- participar mensalmente das reuniões gerais com todos os núcleos.

O trabalho de visita aos núcleos iniciou-se em 1999, com base numa tabela que apresentava o nome de vários núcleos e de seus respectivos coordenadores, repassada pelo coordenador geral da Educafro. Os núcleos contatados estão na Tabela 12. 
Tabela 12: Núcleos da Educafro em 1999, sua localização e número de vagas.

\begin{tabular}{|l|r|r|r|r|}
\hline Nome do núcleo & $\begin{array}{r}\text { Local de } \\
\text { funcionamento }\end{array}$ & Região & Início & $\begin{array}{r}\text { Vagas } \\
\text { oferecidas }\end{array}$ \\
\hline 1. Quilombo Central & Centro & 1997 & 35 \\
\hline 2. Associação Pró-Falcêmicos & Sede Própria & Centro & 1999 & 25 \\
\hline $\begin{array}{l}\text { 3. Jd Miriam - Ig. Nsa. Sra. } \\
\text { Aparecida }\end{array}$ & Igreja & Sul & 1997 & 80 \\
\hline 4. Vila Dionísia & Igreja & Sul & 1998 & 50 \\
\hline 5. Jd. Ângela & Escola Pública & Sul & 1998 & 80 \\
\hline 6. Capão Redondo - CDHEP & Centro de Direitos & Sul & 1998 & 35 \\
\hline 7. Jd. Capela & Igreja & Sul & 1999 & 60 \\
\hline 8. Jd. Primavera & Escola Particular & Sul & 1999 & 80 \\
\hline 9. Jd. Luso/ Cid. Júlia & Escola Pública & Sul & 1999 & 60 \\
\hline 10. Imirim & Comunidade & Norte & S/ inf. & 60 \\
& Eclesial de Base & & & 80 \\
\hline 11. Ponte Pequena - Gaspar Garcia & Centro de Direitos & Norte & S/ inf. & 80 \\
\hline 12. Vila Formosa - Sagrado & Humanos & & & \\
Coração & Igreja & Leste & 1998 & \\
\hline 13. Itaquera & Igreja & Leste & 1999 & 50 \\
\hline 14. Sapopemba & Igreja & Leste & 1999 & 50 \\
\hline 15. Cid. Tiradentes & Igreja & Leste & 1998 & 35 \\
\hline 16. Cid. Tiradentes & Leste & 1998 & 30 \\
\hline
\end{tabular}

Além desses núcleos, a Educafro possui outros em alguns municípios da Grande São Paulo, como Santa Isabel e Osasco, e também em outros Estados, como o de Passos, em Minas Gerais.

Um elemento importante é a inserção que a Educafro possui nas mais diversas regiões, com núcleos em bairros muito distantes do centro e famosos pela violência urbana, como Capão Redondo, Cidade Tiradentes e Jardim Ângela. Mas foi também nos núcleos mais distantes que se constatou a ausência de professores em várias disciplinas e de material pedagógico adequado, e os pré-vestibulares assumiram feições de grupos de estudo, nos quais os próprios alunos tentavam aprender e ensinar.

Os coordenadores dos núcleos, normalmente, são pessoas vinculadas à Igreja local, onde realizam trabalhos comunitários; outra boa parte é formada por alunos bolsistas em universidades particulares. Como a bolsa é obtida pela influência da Educafro junto às universidades confessionais de origem católica, o aluno fica obrigado a prestar serviços comunitários sob pena de perder o benefício; assim, muitos 
acabam tornando-se coordenadores de núcleos ou professores do pré-vestibular. Este também seria um dos objetivos da Educafro: criar uma rede solidária na qual os que recebem algo têm de contribuir de alguma forma.

As aulas de cultura e cidadania têm a mesma carga horária das outras disciplinas que caem no vestibular, de acordo com folheto explicativo de suas ações:

O trabalho comunitário não quer ser uma extensão do automatismo de educação. A coordenação, alunos e professores fazem destes pré-vestibulares espaços alternativos para se discutirem e aprofundarem as grandes questões que angustiam a sociedade. Para isto foi criada a matéria CULTURA E CIDADANIA. (Educafro, 1999(?))

A questão do negro é tema presente na maior parte das aulas. Procura-se com isto despertar questões nos alunos como: "Sou afrodescendente, tenho que ser carente? Por que todo meu povo é pobre? Até quando?" (Educafro, 1999(?)).

Essa matéria não possui professores fixos; há um cadastro de voluntários catalogados por tema, ao qual os coordenadores podem recorrer, convidando-os para discutir com os alunos assuntos específicos. Neste cadastro é possível verificar a presença marcante de professores que ministram aulas relacionadas à negritude. Alguns textos a serem explorados nos núcleos são discutidos nas reuniões mensais, e os coordenadores encarregam-se de levar o debate para seus alunos.

\subsubsection{Grêmio da Escola Politécnica da USP - Cursinho da Poli}

O Cursinho da Poli, organizado pelos alunos do, sendo parte do estatuto desta agremiação, teve o início de suas atividades em 1987, com o incentivo do então diretor da Escola Politécnica, Décio Leal de Zagótis, junto à diretoria do Grêmio.

O Curso Politécnico antecedeu essa experiência, funcionando de 1950 até 1984, e também era organizado pelo Grêmio, mas possuía fins lucrativos e teve a motivação inicial de preparar alunos apenas para o ingresso na Escola Politécnica.

O objetivo do atual Cursinho da Poli é "formar cidadãos conscientes de seu papel na sociedade e capazes de se organizar em grupos para buscar soluções para os seus problemas". E, ainda, de acordo com um de seus diretores: "O cursinho é um projeto político do movimento estudantil de defesa da universidade pública e da 
democratização do ensino. Atualmente é uma referência para o movimento estudantil, pois inova na atuação política." (Cursinho da Poli, nov.1999, p.6-10).

O cursinho cresceu em número de vagas na década de 1990. Iniciou suas atividades em 1987, com 60 alunos; em 1993, possuía 200; em 1996, chegou a 450; em 1999, ofereceu 850 vagas; e no ano de 2000, comportou 8.000 pessoas em suas salas de aula. Esse incremento só foi possível com mudanças nos locais onde eram ministradas as aulas. Se no início das atividades havia o incentivo do diretor da Escola Politécnica e da USP, com mudanças na direção o cursinho acabou sendo expulso das dependências da "Poli", alojando-se por um ano no prédio de aulas da Psicologia da USP e, posteriormente, tendo de alugar sede própria e se reestruturar administrativa, financeira e pedagogicamente.

As aulas, antes oferecidas somente no período noturno, foram organizadas em períodos distintos, com turmas no matutino, vespertino, noturno e aos finais de semana, com maior aproveitamento do local e expansão das vagas.

No ano de 2000 o cursinho passou a produzir seu próprio material pedagógico. Em anos anteriores, as apostilas eram adquiridas de cursinhos comerciais e repassadas aos alunos. Essa nova fase contou com o auxílio de professores da USP no desenvolvimento da forma e do conteúdo das apostilas, que podem ser compradas por colégios, cursinhos e alunos.

Como outros espaços pedagógicos, são oferecidas: orientação vocacional, jornadas de trajetória profissional, sistema informações sobre cursos, palestras com personalidades públicas, aulas de teatro amador, e núcleo de cinema e vídeo. Com a inserção desses novos elementos - nem sempre presentes nos cursinhos comerciais procura-se prestar um serviço de qualidade a baixo custo e também criar espaços culturais e de convivência para os vestibulandos.

O serviço social também está articulado com a proposta do pré-vestibular. Além de realizar a seleção sócio-econômica dos candidatos, ele permanece aberto durante o período letivo para auxiliar aqueles com dificuldades para arcar com as mensalidades, se locomover, pagar a taxa de inscrição dos vestibulares ou outra qualquer. As soluções incluem a discussão sobre estas serem ou não questões isoladas de cada estudante, e a promoção de atividades, como organização de festas ou pedágios para 
arrecadação de dinheiro. Espera-se que o aprendizado ultrapasse a mera questão do vestibular, capacitando o aluno para enfrentar questões do dia-a-dia.

Há ainda vagas reservadas para convênios, como os estabelecidos com a Funap - Fundação de Amparo ao Preso -, para o acolhimento de detentos em regime semiaberto que pleiteiam uma vaga na universidade, e com a Febem - Fundação para o Bem-Estar do Menor -, que visa atender adolescentes com problemas de inserção na sociedade.

O principal elemento que estimulou o crescimento do Cursinho da Poli foi a grande procura. Apenas no ano de 1999, cerca de 15.000 alunos inscreveram-se nos diversos processos seletivos realizados ao longo do ano. Esse enorme contigente de candidatos advém de uma sábia política de recrutamento, com cartazes afixados em trens de metrô, ônibus, aparições em telejornais e outras formas de publicidade diversas, que anunciam a data de inscrição.

Naquele ano, o cursinho ofereceu 850 vagas, com grande número de excluídos no processo seletivo. Por conta disso ele chegou a ser comparado a uma "pequena FUVEST" que, tal como a fundação, sobreviveria do dinheiro da inscrição de pessoas não beneficiadas pelo serviço. De certa forma a crítica foi absorvida pelo cursinho:

10.000 candidatos faziam uma prova de conhecimentos gerais. Apenas 1.250 candidatos passavam para a segunda fase, uma análise sócio-econômica. Selecionávamos por fim uma elite de 850 alunos carentes e bem informados.

9.150 jovens ficavam do lado de fora. Entre eles os mais pobres e desinformados. O seu dinheiro gasto na inscrição para a prova do cursinho pagava parte do curso dos colegas que conseguiam entrar. (O Politécnico, 08 ago. 2001, p.12)

O processo seletivo é pago. No ano de 2000 foram requeridos $\mathrm{R} \$ 5,00$ para a compra do manual e mais $\mathrm{R} \$ 45,00$ de taxa de inscrição. Há duas fases; a primeira consiste num vestibulinho cujos aprovados são em número de uma vez e meia o número de vagas. Na segunda etapa é realizado um exame sócio-econômico do estudante, no qual são exigidos uma série de documentos indicadores de renda, despesas, patrimônio e situação familiar. Após isso, o candidato ainda se submete a uma entrevista com assistentes sociais. 
Sua mensalidade é a mais alta dentre os cursinhos alternativos, chegando a R\$ 100,00 no ano 2000. Esse preço seria resultado da tentativa de oferecer uma aprendizagem de qualidade, com uma série de serviços além do estudo para o exame vestibular, entretanto, o valor é baixo se for comparado ao dos cursinhos comerciais. Há várias bolsas de estudo, que no ano 2000 beneficiaram um total de 1.800 estudantes, com valores que oscilam de 5 a $95 \%$ da mensalidade.

Apesar do preço alto e da concessão de bolsas, a direção alega não estar bem financeiramente; em balanço publicado, acusa-se um déficit de R $\$ 150.000,00$ no ano de 1999 e de R \$ 800.000,00 no ano de 2000. Para cobrir as despesas contou-se ainda, ao longo dos anos, com verbas da USP reservadas para projetos de extensão universitária. (O Politécnico, 08 ago. 2001)

Os professores trabalham em regime formal; muitos são profissionais da área que já tiveram vínculo empregatício em outros locais. Há também ex-alunos da USP, que iniciaram suas atividades profissionais no próprio cursinho. O serviço de plantão de dúvidas é realizado por universitários, cuja meta seria ingressar como docentes; eles nem sempre são remunerados, mas permanecem pela possibilidade de se profissionalizarem; a direção vê o plantão como uma etapa inicial de progressão na carreira.

Historicamente, o cursinho tem um bom índice de aprovação em universidades públicas, com cerca de 30\% de ingressantes. Entretanto há de se ressalvar que até 1999 havia uma concorrida seleção para ser estudante. Com a grande ampliação de vagas em 2000 (que, por exemplo, superam o número de vagas oferecidas na própria USP), a qualidade média dos alunos pode ter caído e, conseqüentemente, a porcentagem de aprovação. Não há estatísticas sobre a matrícula no último ano.

\subsubsection{APROVE - Associação de Professores para o Vestibular}

A APROVE iniciou suas atividades em 1992 com o objetivo de oferecer uma possibilidade para que os alunos de baixa renda pudessem se preparar para o ingresso numa universidade. Ela é uma associação sem fins lucrativos e funciona sob a forma de cooperativa.

A primeira turma foi composta de 35 alunos; as aulas foram ministradas numa escola estadual do bairro Jardim Bonfiglioli, na capital paulista. No segundo ano, 
chegou-se a 500 estudantes, com o cursinho sendo oferecido também em outra escola, agora no bairro de Interlagos. Em 1994 o cursinho mudou-se para uma sede alugada no bairro do Butantã, onde ainda estava no ano 2000 .

As atividades foram ampliadas nesse período, com mais 450 vagas no centro de São Paulo, em 1998, e mais 400 vagas, em 1999, em outro prédio alugado, também no Butantã. As aulas foram distribuídas em diversos períodos: matutino, vespertino, noturno e no final de semana. Isso permitiu que apenas a sede do cursinho abrigasse no ano de 2000 um total de 1.150 estudantes.

A seleção dos alunos, cuja inscrição teve o valor de $\mathrm{R} \$ 30,00$ no ano de 1999, é realizada em dois momentos; o primeiro, com base num vestibulinho; no segundo são requeridos "comprovantes sociais" para efeito classificatório, como contas de luz, IPTU etc.

A renda da APROVE, composta pela mensalidade, que possui como teto $50 \%$ do salário mínimo, e pelo dinheiro arrecadado na inscrição, permite que o cursinho seja auto-sustentável, com o pagamento de despesas como aluguel, gráfica e registro profissional dos docentes.

Os professores são profissionais da área, tendo já trabalhado em outros cursinhos comerciais.

A APROVE produz a sua própria apostila. Além do conteúdo vinculado ao exame vestibular, é oferecida ao aluno uma série de serviços, procurando garantir um ensino de qualidade:

- PLANTÃO DE DÚVIDAS, nos quais o aluno tem acesso a um atendimento mais personalizado de todas as matérias;

- LABORATÓRIO DE REDAÇÃO, local onde o aluno irá desenvolver habilidades para interpretação de textos, bem como elaboração dos mesmos;

- ORIENTAÇÃO VOCACIONAL E PROFISSIONAL, fundamental para o aluno ter certeza na hora de escolher sua carreira;

- CINE APROVE, exibição de filmes de conteúdo didático para melhor compreensão das matérias estudadas;

- APROVEST, informações sobre os cursos das melhores faculdades, bem como disponibilidade de cópias das provas dos principais vestibulares do país;

- APROVEST II, visitas monitoradas aos campus universitários da USP (sic); 
- BIBLIOTECA, acervo de livros didáticos e das obras literárias solicitadas nos vestibulares mais concorridos;

- SIMULADOS, através dos quais o aluno poderá avaliar seu desempenho;

- SEMANA CULTURAL, atividades interdisciplinares para contextualização do ensino;

- EVENTOS DE CONFRATERNIZAÇÃO SOCIAL, Festa Julina, Aniversário da APROVE, Dia do Vestibulando;

- SALAS DE AULA CLIMATIZADAS, para melhor conforto do aluno;

- LOUSA PANORÂMICA C/ TELA PARA PROJEÇÃO, para uma melhor visualização, sendo utilizada também para exibição de filmes e slides;

- RETROPROJETOR, utilizado nas aulas para melhor expressar o conteúdo didático. (APROVE, 1999)

A APROVE tem um retrospecto de cerca de $35 \%$ de aprovação em universidades públicas e particulares.

\subsubsection{Núcleo de Consciência Negra}

O Núcleo de Consciência Negra ( $\mathrm{NCN}$ ) ocupa um antigo prédio da USP no campus Butantã. Suas atividades iniciaram-se em 1987; em 1992 ele foi registrado em cartório como entidade sem fins lucrativos e conseguiu sua sede. O Núcleo foi fundado com o objetivo de discutir as necessidades da comunidade negra na sociedade em geral e, em particular, no meio acadêmico.

Seus integrantes são na maioria pessoas vinculadas à USP, como professores, alunos e funcionários, mas possui também membros externos. Apesar de estar sediado dentro da universidade, o NCN não possui qualquer vínculo formal com ela, e as tentativas de se estabelecer um convênio entre ambas as instituições não lograram êxito. A USP contribui com a concessão do espaço, o fornecimento gratuito de água, luz, telefone, algum material de limpeza e uma cota de 5.000 fotocópias por mês.

Como exemplo de sua atuação fora da USP, o Núcleo encabeçou o movimento pelas reparações, que exigia indenização do governo aos afrodescendentes pelos anos de escravidão, movimento este que já existia nos Estados Unidos, África e Caribe. Também publicou no seu jornal Quilombos matéria que denunciava racismo em um shopping da periferia e pregava o boicote da comunidade negra àquele comércio. $\mathrm{O}$ NCN ainda oferece aulas de idiomas (Inglês, Espanhol e Iorubá), curso de alfabetização de adultos e oficinas de teatro para a dramaturgia negra. 
No combate à exclusão do negro no Ensino Superior realiza, além do cursinho, outras atividades, como a defesa da política de cotas para o ingresso, a qual será abordada em outro momento. O NCN ainda denunciou, no ano de 1999, o fato de o "Manual do Calouro 99" não conter em suas ilustrações nenhuma imagem de pessoa negra:

Nosso entendimento e convicção é que, ao ocultar a imagem do negro em 100\% das ilustrações e fotografias [cerca de 30] vinculadas nesse material de divulgação, a USP está praticando discriminação racial negativa direcionada aos negros. Pois subliminarmente fica entendido que a USP não é lugar para os negros; pelo menos enquanto estudantes e professores. (NCN, Quilombos, abr. 1999, p.2)

O oferecimento do cursinho foi inspirado no projeto da Cooperativa Educacional Steve Biko da Bahia - o primeiro do movimento negro no Brasil -, e procura fornecer uma possibilidade de modificação do atual quadro de ingresso na universidade, indo além da simples denúncia da exclusão educacional do negro.

As aulas iniciaram-se em agosto de 1994. Na primeira aula sequer existiam carteiras; elas foram conseguidas, posteriormente, por meio da doação de carteiras usadas de uma unidade da USP. A primeira turma era composta de 60 alunos; no ano 2000, foram 140 vagas.

Estipulou-se que $70 \%$ de seus vestibulandos têm de ser negros ou mestiços. Para tanto, o recrutamento é realizado preferencialmente em locais onde haja maior presença da comunidade negra, além de divulgação em jornais, cartazes, e indicações de ex-alunos. A seleção, cuja taxa de inscrição foi de R \$ 60,00 no ano de 2000, é realizada em duas etapas, sendo a primeira um vestibulinho e a segunda uma seleção sócio-econômica.

O aluno ainda paga uma quantia mensal semelhante à da inscrição. Em troca, recebe as apostilas utilizadas no curso, que são compradas de um cursinho comercial por um preço menor; a diferença é utilizada para as despesas do Núcleo com coordenadores, professores, secretária e limpeza.

Os professores, remunerados por hora-aula em valor próximo a $\mathrm{R} \$ 15,00$, são, em sua maioria, ex-alunos do próprio NCN que ingressaram na USP. Além deles, há plantonistas voluntários que realizam um projeto permanente de atendimento de 
dúvidas. Reuniões pedagógicas do corpo docente são freqüentes.

O curso oferece 5 aulas de 40 minutos semanalmente no período noturno, nas quais são abordados os conteúdos diretamente relacionados ao vestibular; no sábado há a disciplina "Cidadania e Consciência Negra". Inspirada na proposta baiana, seu conteúdo:

[...] privilegia temas ligados à situação do negro na sociedade brasileira que vão desde racismo até o movimento dos sem-terra e que são tratados através de debates e palestras que reúnem professores da universidade e outros especialistas. (NCN, abr. 1999, p.3)

Assim, superando a mera preparação para o exame, espera-se que o aluno desenvolva uma postura de questionamento sobre a condição do negro na sociedade em que vive.

O cursinho constitui a principal renda do NCN e permitiu que este ampliasse suas ações, como a possibilidade da publicação do jornal Quilombos e a contratação de uma secretária que atende não apenas ao pré-vestibular. Entretanto, as dificuldades financeiras são constantes. A principal causa da desistência dos alunos é o preço; outros ainda têm dificuldade de cumprir o prazo de pagamento das mensalidades - em especial na época da inscrição para o vestibular -, e atrasos na remuneração dos professores são inevitáveis. (Brianezi, 7 a 20 out. 1999, p.3)

A média de aprovação na FUVEST oscilou em torno de 20 a 30\% ao longo dos anos.

\subsubsection{XI de Agosto}

O cursinho surgiu em 1996, a partir da iniciativa dos alunos da Faculdade de Direito da USP, mas não possui vínculos com o órgão de representação dos estudantes, o Centro Acadêmico XI de Agosto. Este apenas ajuda a cobrir as despesas, e, com o tempo, espera-se que apenas o nome seja comum.

Nos primeiros anos as aulas foram na própria faculdade, no Largo São Francisco, passando em 1999 para um prédio alugado no centro da cidade. Sua proposta é a realização de um trabalho social que devolva à sociedade o que a universidade pública já está proporcionando a seus alunos. 
O cursinho possui um acordo com o Anglo, e, por meio dele, compra e utiliza suas apostilas; os professores podem requisitar assessoria, e os aprovados nos vestibulares fazem parte das estatísticas do cursinho comercial. Na parte pedagógica, além de as aulas seguirem as apostilas, há um curso de cidadania no primeiro semestre, e de cultura e artes no segundo, para os quais não há horário específico - ocorrendo nas janelas das outras disciplinas - e tampouco professores - que podem ser convidados externos ou os próprios docentes. A coordenadora pedagógica é formada em psicologia e faz também a orientação vocacional dos alunos.

Os professores dividem-se em três categorias; alguns também ministram aulas no Anglo, outros são alunos da própria universidade, e uma terceira parte são estudantes da USP em geral. Não há registro profissional, eles somente recebem R\$ 10,00 por hora-aula a título de reembolso de despesas.

A verba para a manutenção provém do dinheiro obtido com a inscrição dos candidatos - quando são cobrados $\mathrm{R} \$ 3,00$ para a aquisição do manual, e $\mathrm{R} \$ 42,00$ para a realização do vestibulinho - e com as mensalidades - que são em número de oito, com valor de $\mathrm{R} \$ 55,00$, e incluem o recebimento de uma apostila. $\mathrm{O}$ vestibulinho constitui a primeira etapa da seleção dos alunos; a segunda é sócio-econômica.

São oferecidas 300 vagas no total, divididas igualmente nos períodos diurno e noturno.

\subsubsection{JOC-Juventude Operária Católica}

A Juventude Operária Católica é uma organização vinculada à Igreja Católica e sobrevive de financiamento internacional.

O Cursinho da JOC começou a existir em 1996 como um grupo de estudos composto por pessoas da própria organização que desejavam o ingresso no Ensino Superior. Até então, ele contava com 20 alunos e o auxílio de alguns professores voluntários, e funcionava aos sábados, durante o dia inteiro, e aos domingos, pela manhã.

Ele passou a integrar o projeto da EDUCAFRO em 1997, e, com isso, várias modificações ocorreram. Quanto à seleção dos alunos, foram incorporados os quesitos de privilegiar o aluno afrodescendente e o número de anos que está distante da sala de aula; instituiu-se a cobrança de uma taxa para alimentação e auxílio transporte dos 
professores; passou-se a ter a aula de cidadania como disciplina normal do currículo. Além disso, o projeto foi divulgado em uma escola pública, o que aumentou a procura e o número de alunos para 30.

Em 1999, o cursinho saiu da sede da JOC e as aulas passaram a ser ministradas em uma universidade particular com capacidade para 90 alunos. Em troca da cessão do espaço, o projeto foi incorporado como uma atividade de extensão dessa universidade, que recebe relatórios mensais sobre as atividades desenvolvidas. $\mathrm{O}$ cursinho continuou a funcionar aos sábados, das 9:00 às 18:00 horas.

No segundo semestre de 1999 a direção da JOC decidiu romper com a EDUCAFRO e tornar-se independente. Isso ocorreu por desavenças quanto à forma de concessão de bolsas da Universidade São Francisco. O diretor-executivo da EDUCAFRO, que é franciscano e tinha obtido as bolsas, não aceitou entrar em atrito com seus pares.

A JOC continuou a oferecer o cursinho no ano de 2000, com o mesmo modelo do ano anterior, mas de forma independente.

\subsubsection{Centro Comunitário de Estudos Paulo Freire}

A idéia do oferecimento do pré-vestibular nasceu em 1996, numa discussão sobre cotas para negros ocorrida na USP. Na ocasião, os coordenadores conheceram as propostas do Núcleo de Consciência Negra e da EDUCAFRO. Formado basicamente por ex-alunos da USP, sendo alguns militantes do movimento negro e outros, de um partido político, foi consenso entre o grupo que compõe o centro comunitário oferecer o serviço fora da universidade.

O cursinho Paulo Freire iniciou suas atividades em 1997 oferecendo 100 vagas; em 1998 chegou a comportar 120 alunos; e no ano de 1999 ampliou para 210 estudantes. As aulas iniciaram-se numa sala localizada no Parque Bristol, próximo ao Zoológico. Ainda no ano de 1997, transferiu-se para a Escola Estadual Armando Machado, onde permaneceu. A escolha do local se deu pela proximidade que um dos integrantes tinha com a Sociedade Amigos de Bairro.

Para elaborar o processo seletivo, optou-se por pensar em quais pessoas gostaria-se de ter em sala de aula. Foram, assim, definidos vários critérios de inclusão: participação em movimentos sociais, tempo de afastamento dos estudos, se é negro ou 
afrodescendente, e se cursou a escola pública. Também é dada preferência às mulheres. Espera-se que os alunos que tenham participação em movimentos sociais possam enriquecer as discussões em sala de aula e manter atividades junto ao grupo do Paulo Freire. Após a seleção, há a formação de uma lista de espera, com a reposição de vagas em caso de evasão dos estudantes.

Os alunos contribuem voluntariamente com uma taxa mensal de $\mathrm{R} \$ 10,00$. O valor total arrecadado subsidia o material utilizado, o lanche e o passe dos professores, e um funcionário que permanece aos sábados durante o período das aulas. A iniciativa chegou, no início, a receber apoio do DCE da USP, da Apeoesp e da Sociedade Amigos do Bairro.

Seus professores têm formação variada. A maior parte deles cursa o mestrado e o doutorado na USP; outros são estudantes universitários; dentre estes, há alguns exalunos do próprio cursinho. Devido à boa qualificação dos docentes, aposta-se, com o tempo, na confecção de um material didático de boa qualidade.

Para as aulas de Cultura e Cidadania eram chamados vários palestrantes; porém, na avaliação dos coordenadores, esse sistema acabava sendo meramente informativo. No segundo ano optou-se pela discussão de temas como poder, ideologia, direitos humanos, cidadania, tendo professor fixo e caráter formativo.

O grupo de educadores procura desenvolver discussões sobre o vestibular para que se proponham políticas de acesso ao Ensino Superior, tendo já participado de manifestações pela isenção da taxa da FUVEST. Para eles, sem essa discussão fica-se a reboque dos acontecimentos diários, e não se interfere decisivamente para a democratização da matrícula.

Os organizadores relataram que $20 \%$ de seus alunos entraram em cursos superiores públicos no ano de 1998.

\subsubsection{Alunos da PUC-SP}

O cursinho organizado por alunos da PUC-SP, sediado nesta mesma universidade, teve início no ano de 1997. A idéia de oferecer este serviço partiu de contatos realizados através do NEAFRO - Núcleo de Estudo da Afrodescendência -, com pessoas que estavam organizando núcleos da EDUCAFRO em outras instituições do movimento negro. 
A reitoria da PUC inicialmente resistiu à idéia de ceder espaço para esta atividade, mas ao final do primeiro ano passou a colaborar na cessão de salas.

No primeiro ano foram oferecidas vagas a todos os que se inscreveram, num total de 420 pessoas; já em 1998 os coordenadores realizaram uma divulgação nas escolas públicas das regiões com alto índice de exclusão social, chegando a ter 2.920 candidatos para as 600 vagas oferecidas. O alto número de evasões no segundo semestre desestimulou os organizadores, que diminuíram as vagas. No ano de 1999, sem publicidade sobre a existência do cursinho, foram 400 os estudantes aceitos.

A seleção dos alunos é realizada de forma variada, podendo contar com comprovantes de renda, carteira de trabalho, holerites, despesas de água e luz e visitas às residências. É dada a preferência para negros que há mais tempo estão distantes da escola.

Não é cobrada qualquer taxa de inscrição ou mensalidade, só se pedem, no início do ano, 1.000 folhas de papel, utilizadas para confecção de apostilas, de material didático, e para pagamento do trabalho da fotocopiadora (que normalmente é vinculada aos Centros Acadêmicos dos alunos da PUC).

Os professores são, em sua maioria, universitários da PUC e nada recebem pelo trabalho realizado. O curso é organizado pelo próprio docente da disciplina, e, durante as férias de julho, realizam-se oficinas com temas variados, como ética, cidadania, etnia, globalização, sexualidade, dentre outros.

\subsubsection{AEUSP - Associação de Educadores da USP}

Formou-se uma associação de educadores entre os estudantes da USP com a expectativa de montar uma escola popular e trabalhar com educação de adultos. O prévestibular seria uma primeira etapa estruturadora para alcançar os objetivos maiores; ele inserir-se-ia num projeto interdisciplinar denominado "a socialização e a construção do conhecimento pela classe trabalhadora”. Para os coordenadores, a opção de trabalhar com educação já constitui um projeto político, e a oferta de um cursinho que pretende levar o estudante desfavorecido economicamente à universidade pública é um projeto social. 
A AEUSP é uma entidade sem fins lucrativos, fundada legalmente em 1998, com a finalidade de desenvolver ações que promovam a educação formal e informal, o acesso e a interação com as mais variadas formas de cultura e artes pela classe trabalhadora.

[...] a AEUSP vem se destacando pelas inúmeras iniciativas de educação popular, sempre buscando parcerias com a sociedade civil organizada - Associações, igrejas, sindicatos, partidos políticos, escolas públicas e municipais, universidades etc. (AEUSP, 10 mai. 2001)

Todos os integrantes já possuíram uma relação com a AMORCRUSP Associação de Moradores do Conjunto Residencial da USP (CRUSP). A sede da AEUSP situa-se nesse conjunto, e o projeto é conhecido como "Cursinho da AMORCRUSP" informalmente. Não há qualquer vinculação direta com a universidade, embora a Faculdade de Educação tenha doado carteiras usadas e a sede esteja localizada em espaço pertencente à universidade.

Após quase um ano de discussões, a primeira turma do cursinho formou-se em setembro de 1998, iniciando com 80 alunos e terminando com 35. No ano de 1999 foram 120 vagas no Município de São Paulo, e outras em Osasco. Na capital, os locais das aulas são próximos à USP, nos bairros do Butantã e Jaguaré, em espaço cedido por uma igreja católica e num diretório de partido político. No ano de 2000 utilizaram-se salas de escolas públicas desse mesmo bairro.

Os professores e coordenadores, na maioria estudantes da USP de graduação e pós-graduação, tiveram, em 1999, remuneração fixa de $\mathrm{R} \$ 200,00$. O dinheiro para pagamento foi arrecadado com a taxa de inscrição e as mensalidades respectivamente $R \$ 30,0$ e $R \$ 40,00$-, e a inscrição já se constituía como a primeira mensalidade.

A seleção dos alunos é composta de uma redação, a fim de realizar um diagnóstico da pessoa, e de um processo de avaliação sócio-econômica, que tem como um dos seus principais critérios a localização geográfica do estudante. Os ex-alunos continuam no curso se quiserem, não sendo necessário passar pela seleção novamente.

$\mathrm{Na}$ área pedagógica, os professores confeccionam as apostilas utilizadas e procuram oferecer uma abordagem interdisciplinar dos conteúdos, com freqüentes reuniões pedagógicas. Há um espaço semanal para oficinas temáticas com conteúdo variado.

No primeiro ano, 35 alunos terminaram o curso; destes, três conseguiram o 
ingresso em universidades estaduais (2 na UNESP e 1 na UNICAMP), e os outros, em particulares.

\subsubsection{CAEHUSP - Centro Acadêmico de Estudos Homoeróticos ${ }^{11}$}

O CAEHUSP foi formado por alguns estudantes da USP que em 1992 formaram o GLUSP - Gays e Lésbicas da USP. Em 1995 foi registrado em cartório o CAEHUSP com os seguintes objetivos:

O CAEHUSP tem duas linhas de atuação. A primeira tem como objetivo reunir informações sobre o tema "homossexualidade", desenvolvendo pesquisas acadêmicas e incentivando novos pesquisadores.

A segunda procura, através da realização de eventos e atividades lúdicas, promover a construção da auto-estima dos GLTs ${ }^{12}$. Nesta segunda linha, o trabalho com prevenção à DST/ AIDS tem-se mostrado bastante pertinente e eficaz. (CAEHUSP, 1999, p.2)

Ainda em 1996, o CAEHUSP também lançou uma revista com o objetivo de ser um "Manual do Calouro Gay", abordando temas como os melhores espaços a serem freqüentados na USP (vestiários, praças e outros locais), dicas de prevenção da AIDS (uso de preservativos etc.), atividades culturais e de lazer (como filmes e bares voltados para o público gay).

Procurando ser um elemento transformador da sociedade, o CAEHUSP montou um pré-vestibular para atender uma camada mais pobre da população, afim de que esta consiga ingressar na universidade, uma vez que o preço dos cursos comerciais seria proibitivo. Além disto:

O seu objetivo é desenvolver nos alunos capacidade não apenas para conseguir um bom desempenho no vestibular, mas também de influir no futuro da

\footnotetext{
${ }^{11}$ O homoerotismo foi assim colocado:

Prefere-se o termo "homoerotismo" para indicar as práticas e relacionamentos entre pessoas do mesmo sexo, em todos os tempos. Ao contrário de "homossexualismo", que, antes de tudo, pressupõe mero encontro sexual, "homoerotismo" significa a prática de Eros, amor, paixão e sexo se misturam. Os homens não apenas fazem sexo com homens, os homens amam outros homens. As mulheres não apenas curtem o sexo, elas desenvolvem relações afetivas muito duradouras. (CAEHUSP, Revista do CAEHUSP, Março de 1996:5. Grifos do autor)

${ }^{12}$ Gays, Lésbicas e Transgênicos.
} 
sociedade, adquirindo um espírito crítico e consciente acerca das questões de cidadania e de direitos humanos. (CAEHUSP, 1999, p.6)

Para atingir esses objetivos, as aulas são oferecidas numa sala pequena, com vistas a aproximar alunos e professores, fornecendo um ensino humanístico; também há a disciplina de Direitos Humanos sem carga horária definida, que pode ser ministrada na falta de algum professor, ou previamente agendada.

No processo seletivo há, inicialmente, uma prova composta de 42 testes que abrangem o conhecimento do Ensino Médio e tem peso igual a 1 no resultado final; a segunda etapa consiste em uma avaliação sócio-econômica, com peso 2, na qual o candidato apresenta indicadores como conta de luz ou água, recibo de aluguel, número de pessoas por residência, declaração do imposto de renda etc. Para o aluno participar da seleção são cobrados $\mathrm{R} \$ 35$ mais $\mathrm{R} \$ 2$, relativos à compra do manual. Os alunos são classificados nas 60 vagas disponíveis.

No panfleto da Festa de Lançamento, que foi realizado numa casa noturna, o cursinho é colocado como o "pré-vestibular mais cobiçado entre os estudantes" e as pessoas são convidadas a estudar "num lugar onde os professores entendem você" (CAEHUSP, s/ data). Em outro cartaz, divulgado provavelmente no período de férias letivas, os alunos eram convidados a se matricular no cursinho: "Chega de excursão! Agora só cursinho. Pacote turístico de 6 meses pelas áreas de exatas, humanas e biológicas. [...] Prepare-se para entrar na USP - praticamente R\$ 1,99 por dia. Embarque logo neste pré-vestibular e boa viagem!” (CAEHUSP, s/ data).

No manual do candidato há ainda um questionário que deve ser respondido pelo aluno, no qual, além de questões relacionadas ao conhecimento sobre DSTs/ AIDS, o candidato responde a questões sobre sua orientação sexual (heterossexual, homoerótica ou bissexual) que são mantidas em sigilo. Cerca de 30\% dos ingressantes de 1999 declararam não serem heterossexuais, e este fator não teve qualquer influência na seleção.

Os professores vinculados ao CAEHUSP são voluntários; outros chegam a receber R\$10,00 por hora-aula. Utilizam-se apostilas de um curso comercial semiextensivo.

Parte do financiamento da entidade provém do pré-universitário, porém ainda 
há doaçõesdos coordenadores, verba arrecadada em festas e bazares, doações de pessoas e de entidades como a Comunidade Cristã Gay. As carteiras foram doadas pela FFLCH-USP.

\subsubsection{Movimento Humanista}

O Movimento Humanista possui caráter internacional e tem propostas de humanização, como não-violência, não-discriminação, solidariedade e o fim da injustiça.

Considerando como ideal o direito a uma vaga para todos que desejam cursar a universidade pública, a proposta de um pré-vestibular para os estudantes mais pobres tenta apenas nivelar as oportunidades e reduzir a desigualdade no ingresso. Em um dos cartazes que recrutam professores voluntários, esta é colocada como uma iniciativa de democratização das universidades públicas. (Movimento Humanista, s/ data)

A idéia para a fundação do primeiro núcleo nasceu quando um membro, que queria ingressar na universidade, pediu auxílio aos companheiros do Movimento Humanista para formar um grupo de estudo. Pensou-se, então, na formação de uma turma. Um dos professores convidados trouxe a experiência do cursinho dos Alunos da PUC-SP, o que auxiliou no delineamento da forma de organização.

O projeto tem como objetivo que os alunos criem autonomia, e que ela possa ser levada para outras iniciativas que tenham em suas vidas. Esse objetivo reflete-se também nos critérios de seleção, em que se privilegiam aqueles que possuem participação em movimentos sociais e disponibilidade para auxílio na organização do pré-vestibular. Além disso, considera-se a tendência do estudante permanecer até o final das atividades e que estes sejam oriundos da escola pública, com a necessidade de apresentação de algum certificado.

Na seleção, verifica-se o tempo de estudo de que o aluno irá dispor além dos sábados, o que acontece por duas razões: para averiguar o interesse na matrícula numa universidade, e também porque os coordenadores entendem que um único dia de estudo é insuficiente para a aprovação nos melhores vestibulares. A atividade do cursinho, tal como está organizada, seria uma orientação para o aprofundamento dos estudos em outros espaços. 
Como estímulo para o estudante desenvolver sua autonomia, ele sempre é colocado em alguma comissão para auxiliar o cursinho, cuidando de atividades como fotocópias de apostilas, limpeza do local e convocação de professores. A não participação nesse auxílio não implica em exclusão do projeto. Há janelas entre as aulas que são utilizadas para a auto-organização e, por vezes, também para a discussão de temas sociais.

O montante arrecadado através da mensalidade e da taxa de inscrição - a partir de $\mathrm{R} \$ 5,00$, valor pensado de forma a não ser impeditivo para estudantes de baixa renda - é utilizado para cobrir despesas com material de aprendizagem e manutenção do local. Entende-se o pagamento como essencial, uma vez que não se trata de uma ação de caráter "assistencialista" e na qual todos têm de se sacrificar um pouco para a existência do pré-vestibular.

Os docentes são todos voluntários e a maioria deles é composta de estudantes universitários recrutados através de cartazes que são espalhados em seu local de estudo, sendo que poucos têm experiência didática. Eles podem receber, caso estejam em dificuldade, ajuda para o transporte. Não há seleção para professores; procura-se aproveitar todos que queiram ministrar aulas. Não há material pedagógico próprio; os professores organizam as apostilas e listas de exercício. Muitas vezes os alunos também trazem contribuições para as aulas.

Em 1998 três núcleos estavam em funcionamento, na Vila Mariana, na Vila Santa Catarina e em Guaianazes, totalizando 140 vagas. Já em 1999 os núcleos existentes ofereceram 240 vagas nos bairros da Liberdade, Vila Mariana, Aclimação, Sapopemba e Saúde. O local é sempre cedido gratuitamente, com aulas em escolas públicas e particulares, Sociedade Amigos de Bairro, sindicatos e entidades religiosas. Em 1999 e 2000 o Movimento Humanista manteve núcleos também nas cidades de Osasco e Carapicuiba, na Grande São Paulo.

Os núcleos foram fundados pelos integrantes do movimento - apenas um deles partiu de iniciativa de um grupo de estudantes - e todos são coordenados por pessoas vinculadas à organização humanista.

Não há informação sobre o sucesso dos alunos nos diversos vestibulares. 


\subsubsection{IAPSI - Instituto de Atividades Psicossociais}

Este pré-vestibular é organizado pelos alunos do curso de Psicologia da USP através do IAPSI - Instituto de Atividades Psicossociais -, que foi fundado para apoiar projetos de extensão oriundos do corpo discente e não possui vinculação direta com o Centro Acadêmico Iara Iavelberg, dos alunos de Psicologia.

A idéia nasceu a partir de uma experiência vivida em 1997, quando o Cursinho da Poli, sem prédio, foi "hospedado" no IPUSP - Instituto de Psicologia da USP. Na ocasião, alguns alunos que trabalharam naquele pré-vestibular observaram a enorme procura existente e a carência de outros espaços semelhantes para a população de baixa renda, e imaginaram organizar serviço semelhante. Em 1999 iniciaram-se as aulas do cursinho.

Os objetivos do pré-vestibular são os seguintes:

- Possibilitar aos estudantes de baixa renda o acesso ao Ensino Superior nas universidades públicas, na tentativa de promover a democratização da educação;

- promover atividades extras, que não se limitem ao conteúdo do vestibular, com a finalidade de ampliar a visão geral do aluno. São exemplos disso as aulas de lógica, teatro amador, palestras de psicologia e organização de várias atividades culturais;

- criar condições e apoiar iniciativas para que os alunos de baixa renda possam se inscrever nos diversos vestibulares, participando das reivindicações por isenção e incrementando as políticas correlatas já existentes, tais como as da FUVEST, UNICAMP e VUNESP;

- dedicar-se por uma escola gratuita e de qualidade;

- quanto a projetos sociais: buscar apoio dos setores da sociedade; estimular e apoiar as iniciativas existentes e que surgirem; e formar agentes multiplicadores;

- produzir conhecimento para a Psicologia, enquanto Ciência, e para a Educação, ao assumir compromisso com a pesquisa científica, formação e extensão universitária dirigida para a sociedade. (IAPSI, maio 2000)

As aulas ocorrem no prédio do IPUSP, no período noturno e aos sábados. Como contrapartida pela cessão do espaço, os organizadores fazem a manutenção do prédio e equipam as salas de aula. $\mathrm{O}$ cursinho recebe ainda uma cota de 5.000 fotocópias e a permissão para utilizar os computadores da sala pró-aluno. Como outros apoios, ainda conta com uma empresa fabricante de papel, que doa material para impressão, e uma empresa de ônibus, que divulga o cursinho. 
Os alunos têm de pagar uma taxa de $\mathrm{R} \$ 35,00$ para concorrer a uma vaga. Eles são avaliados por um vestibulinho, numa primeira etapa, e, posteriormente, por uma seleção sócio-econômica, na qual é verificada a renda per capta familiar. O públicoalvo constitui-se de jovens e adultos de baixa renda que tenham realizado o Ensino Médio preferencialmente em escola pública e que possam arcar com as despesas do cursinho. Além disso, foi estabelecido um convênio com a Fundação Ayrton Senna para o acolhimento de dez alunos atendidos pela fundação e sustentados por empresas.

São oferecidas trezentas vagas; é formada uma lista de espera daqueles que não obtiveram classificação inicial e que poderão ingressar quando da ocorrência de evasão. Pode ser realizada também uma outra seleção no segundo semestre.

A inscrição e as mensalidades, estas com valor de $\mathrm{R} \$ 65,00$, compõem a renda do cursinho. No pagamento de cada mensalidade o aluno recebe uma apostila confeccionada por um cursinho comercial.

$\mathrm{Na}$ parte pedagógica há liberdade para os professores elaborarem material próprio e independente do conteúdo existente nas apostilas. O cursinho que vende as apostilas também oferece assessoria aos docentes. Como já descrito nos objetivos, há também atividades pedagógicas diferenciadas, como teatro, palestras e aulas de tai-chichuan, que procuram ampliar a visão geral do aluno. Além das aulas, o aluno tem acesso a um plantão dúvidas.

Os professores são, em sua maioria, universitários da própria Psicologia e advindos de outros cursos e universidades. Alguns já são profissionais da área, tendo trabalhado em colégios particulares e cursinhos comerciais. $O$ trabalho não é registrado em carteira e a remuneração é por hora-aula. Os coordenadores e plantonistas também recebem contrapartida financeira.

No sítio do cursinho é possível observar a aprovação de seus alunos em cursos superiores públicos nos anos de 1999 e 2000. No primeiro ano foram aprovadas 23 pessoas, sendo 18 na FUVEST, 3 na UNESP e 2 na UFSCar; no ano de 2000 esse número cresceu para 33, sendo 13 na UNESP, 11 na FUVEST, 2 na UFSCar, 2 na FATEC, 3 na UEL, e 1 na UFSC. (IAPSI, 22 set. 2001a) 


\subsubsection{Thema Educação - cursinho comunitário para negros e estudantes de baixa} renda

O Thema Educação iniciou suas atividades em 1998, oferecendo aulas em uma escola estadual. No ano seguinte, algumas aulas foram ministradas no salão de uma igreja e, posteriormente, transferidas para uma escola particular confessional, sempre no bairro do Tucuruvi.

A principal coordenadora do núcleo havia sido militante do movimento negro na década de 1970, onde deu aulas em uma escola de samba localizada numa favela. Após longo intervalo retomou as atividades de militante inspirada no projeto educacional da EDUCAFRO. Durante o ano de 1998 o Thema esteve vinculado à EDUCAFRO; a separação se deu no segundo semestre de 1999, devido a desavenças quanto à forma de concessão de bolsas em universidades particulares.

Suas metas são assim descritas:

a) Apoiar a formulação e implementação de políticas públicas e privadas e de ações sociais em face à desigualdade existente no País, visando a plena realização do direito ao desenvolvimento. b) Incentivar projetos educacionais e orientação vocacional para jovens e adultos excluídos, visando pleno desenvolvimento da pessoa, seu preparo para exercício da cidadania e sua qualificação para o trabalho. c) Propor e apoiar políticas compensatórias que promovam, social e economicamente, a comunidade negra e estudantes de baixa renda. d) Objetiva-se nesse projeto educacional o resgate da democracia. Valorizar a essência e capacidade individual dos alunos excluídos, com fins de contribuir para o processo de democratização do Estado e da sociedade brasileira a partir da construção e expansão da cidadania. E) Desenvolver oficinas de formação e capacitação educacional, bem como cursos seminários e palestras relacionadas com a diversidade, de gênero e raça, cidadania, para professores e o coletivo do Thema f) Fomentar, estimular e dar apoio a novos projetos sociais e educacionais. (Thema, 2000(?), p.2)

Nesses objetivos transparece que a atividade do Thema não se resume ao oferecimento de aulas no curso preparatório, mas também inclui pensar outras formas de inserção do estudante negro e de baixa renda no Ensino Superior, com a discussão e proposição de políticas públicas específicas para esse fim, além de realizar um debate sobre as condições do Estado brasileiro.

O projeto procura inserir o aluno na rede de Ensino Superior e também auxiliálo nesta empreitada, podendo fornecer auxílio monetário àqueles que estiverem em 
dificuldades no início de sua nova trajetória escolar.

A inclusão do termo "negro" junto ao nome do cursinho visa atrair esse público específico para as aulas; entretanto, no processo seletivo não é dada qualquer preferência a pessoas negras. Na concepção dos coordenadores é de responsabilidade de todos, independente de raça ou cor, discutir e agir pela igualdade na população.

A seleção dos alunos é composta do preenchimento de dois questionários e de uma prova, em que são avaliadas as condições sócio-econômicas e educacionais do candidato. Evita-se fazer uma grande divulgação da existência do cursinho; são espalhados poucos cartazes pela periferia da zona norte de São Paulo, e a principal divulgação ocorre de maneira informal, pelo "boca a boca". Desta forma, praticamente não existem excluídos no processo de seleção, procura-se apenas afastar os que se interessam unicamente pelo baixo preço das taxas cobradas.

No primeiro ano foram 100 vagas oferecidas; depois esse número subiu para 150. Não há qualquer intenção de nova ampliação, porque se pretende um trabalho de qualidade, com a formação de agentes sociais, com a expectativa de que os alunos atuem em trabalhos sociais com os quais se identifiquem e sejam multiplicadores do trabalho de conscientização realizado no Thema. Para isso, contam com menos estudantes, esperando que a proximidade possa favorecer a reflexão e combater a exclusão educacional e cultural pela qual passa o aluno de baixa renda.

Essa posição foi inspirada no trabalho realizado na década de 1930 pela Frente Negra Brasileira, que lutou pela educação da população negra, alcançando este objetivo para uma pequena parcela de pessoas, que posteriormente vieram a se tornar lideranças do movimento negro.

Quanto à didática, é oferecida a disciplina de cidadania, na qual privilegia-se o tema do negro, sua história, condição atual, auto-estima e direitos, e também uma reflexão sobre os direitos do cidadão. Neste segundo ponto, há a leitura da Constituição Federal da República Federativa do Brasil e da Declaração Universal dos Direitos Humanos.

São oferecidos também orientação vocacional, qualificação profissional, ensino de idiomas e plantão de dúvidas. As disciplinas regulares são matemática, português, redação, história e geografia (geral e do Brasil), física, química, biologia e cidadania.

O material pedagógico é próprio e confeccionado pelos professores, que são 
todos voluntários. Sua formação é variada, predominando estudantes universitários e alunos do próprio cursinho que dominem uma disciplina. $\mathrm{O}$ cursinho recebe apoio do Centro Acadêmico Oswaldo Cruz, da Faculdade de Medicina da USP, que organiza professores e espaços para as aulas de química e biologia.

Procurando ser uma alternativa para estudantes de baixa renda, a mensalidade não é superior a $10 \%$ do salário mínimo, quantia utilizada para cobrir os custos com o transporte dos professores, lanche e material pedagógico. Com vistas a suprir dificuldades financeiras do Thema, a associação foi registrada em cartório unicamente com o objetivo de receber doações, fato que ainda não ocorreu.

No ano de 2000, trinta e oito estudantes realizaram os exames para universidades estaduais paulistas; destes, oito foram aprovados - quatro na USP, sendo um em Pedagogia, dois em História e outro em Engenharia; três na UNESP, sendo dois em Geografia e outro em Pedagogia; e na UNICAMP ocorreu uma aprovação em Pedagogia, resultando em $21 \%$ de sucesso. Foram ainda registrados ingressos em instituições particulares.

\subsubsection{Centro Acadêmico Visconde de Cairu}

Motivada por uma pessoa que já havia trabalhado nos cursinhos da Psico e da Poli, surge no CAVC, no início de 2000, a idéia de oferecer um cursinho prévestibular. O Centro Acadêmico assumiu o projeto, tendo como objetivo básico: "democratizar o acesso à universidade pública e à educação de qualidade, dando condições de estudo a quem não tem meios de pagar um cursinho tradicional". (CAVC, 2000, p.2)

A expectativa inicial era que os alunos ingressassem na USP. Com a constatação de que poucos teriam condições de enfrentar este vestibular mais concorrido, passou-se a considerar a importância do ingresso em outras faculdades e também a utilidade que o conhecimento adquirido poderia ter para o estudante em outros espaços, como o do trabalho.

O cursinho é vinculado ao Centro Acadêmico como um projeto social desta organização, que se responsabiliza juridicamente pela sua atividade e conta bancária. A coordenação do cursinho é independente e tem liberdade para desenvolver suas 
ações, contando com uma sede própria no prédio da faculdade, dotada de biblioteca, computadores, arquivos e espaço para reuniões.

A primeira turma começou a ter aulas no período noturno no segundo semestre daquele ano com 140 alunos. As aulas foram ministradas com base em apostilas de um curso semi-extensivo de um cursinho comercial, mas o material não agradou aos coordenadores e professores, pela sua má qualidade e atraso na entrega.

A renda do cursinho advém de duas fontes: as taxas pagas pelos alunos (inscrição e mensalidade) e os acordos realizados com as três fundações ligadas à Faculdade de Economia, Administração e Contabilidade da USP. No acordo firmado, cada uma doou R\$ 4.000,00 para o funcionamento do cursinho, e, em troca, este reservou 20 vagas exclusivas para funcionários da FEA e fundações.

A taxa de inscrição foi de $\mathrm{R} \$ 40,00$, e as mensalidades, de $\mathrm{R} \$ 70,00$. Segundo os coordenadores, o valor da inscrição é fundamental para cobrir os gastos do final de ano, quando boa parte dos estudantes se evade ou não tem dinheiro para pagar as mensalidades, já que muitos têm de optar entre pagar o cursinho ou a inscrição para o vestibular. O cursinho ofereceu bolsas de estudo parciais para os cinco melhores colocados no processo seletivo.

A seleção dos estudantes foi composta de duas etapas. A primeira consistiu numa prova com 70 questões de múltipla escolha e baseou-se no conteúdo das disciplinas do Ensino Médio (matemática, português, química, física, história, geografia e biologia). A segunda fase foi composta de uma entrevista na qual os aprovados deveriam apresentar uma série de documentos sócio-econômicos (declaração do imposto de renda, holerites, recibos de aluguel, despesas com taxas habitacionais, certidão de casamento, recibos de matrícula em estabelecimentos educacionais etc.). Os candidatos foram atraídos através de cartazes afixados em pontos de ônibus da cidade universitária e também de panfletagem realizada pelos coordenadores no metrô.

Os professores são recrutados via cartaz e passam por uma seleção composta de análise de currículo, entrevista e aula teste para avaliação da didática. É dada a preferência a alunos e ex-alunos da USP e pessoas que já tiveram experiências em colégios e cursinhos. A remuneração por hora-aula foi de $\mathrm{R} \$ 15,00$, acrescida de mais $25 \%$ por hora-atividade (para preparação das aulas), totalizando $\mathrm{R} \$ 18,75$; as aulas 
extras e palestras são remuneradas à parte. Não há registro profissional em carteira, pois o custo inviabilizaria o projeto.

Há também a atividade de plantonista, o qual recebe uma ajuda de custo e normalmente é um aluno da FEA. Os coordenadores procuram com isso atrair e envolver mais estudantes da própria faculdade. Todos os coordenadores (cerca de dez) são voluntários.

Todas as aulas são de responsabilidade dos professores, não há uma coordenação pedagógica. Passar filmes, levar ao teatro e a palestras sobre temas específicos são outras atividades existentes, mas não há um horário específico e tampouco um objetivo definido.

No ano 2000 trabalhou-se inicialmente com 140 alunos; destes, apenas 70 chegaram até o final do curso em dezembro, sendo que quatro estudantes foram aprovados na USP, um na UNESP e outros 33 em cursos particulares.

\subsubsection{Alunos da Química USP}

A iniciativa de montar um cursinho alternativo partiu da diretoria do Centro Acadêmico dos estudantes do Instituto de Química da USP no ano de 2000. A expectativa era oferecer um serviço aos vestibulandos impossibilitados de pagar as taxas de um cursinho comercial.

A primeira turma teve início em março; a segunda, em maio; ambas com 80 alunos. As aulas foram ministradas em salas cedidas pelo Instituto no período noturno.

Antes do ingresso, os alunos responderam uma prova de múltipla escolha na qual havia um cabeçalho com várias informações sobre o candidato. Nenhum candidato foi excluído; a prova tinha apenas a função de exercer um controle sobre o número de alunos e fornecer uma ficha sobre cada aluno, pois inexistiam critérios seletivos. Os alunos foram atraídos através de panfletagem em escolas públicas e de cartazes afixados em pontos de ônibus da cidade universitária.

Os professores eram estudantes de graduação, pós-graduação e pessoas próximas aos coordenadores do cursinho. Alguns receberam por hora-aula, enquanto os mais envolvidos com o projeto, e os coordenadores, trabalharam voluntariamente.

Inicialmente, o material didático era confeccionado pelos professores sob a forma de apostila; com o decorrer do curso, optou-se pela compra de material de 
cursinhos comerciais, já que os preços de confecção e compra eram semelhantes, e o material próprio possuía qualidade gráfica inferior (ausência de cores, figuras etc.).

Durante o curso foi realizada uma única atividade extra classe; uma visita recreativa aos laboratórios do Instituto de Química, inexistindo outros espaços pedagógicos que não vinculados diretamente ao conteúdo do vestibular.

A renda do cursinho veio da cobrança da taxa de inscrição $(\mathrm{R} \$ 25,00)$ e das mensalidades ( $\mathrm{R} \$ 50,00)$. Não havia maior controle sobre o dinheiro que entrava e saía; este era controlado através da venda de apostilas, repassadas no momento em que o aluno pagava a mensalidade. $\mathrm{O}$ cursinho terminou suas atividades devendo para professores e fornecedores de apostilas, ônus que foi assumido pelo Centro Acadêmico. O prejuízo constituiu-se no principal motivo para o término do cursinho naquele mesmo ano.

Dos 180 estudantes que iniciaram, apenas 20 chegaram até o final do curso em dezembro, e não se fez nenhum levantamento sobre o ingresso em cursos superiores.

\subsubsection{Clube das Mães do Brasil}

O cursinho nasceu da iniciativa de dois estudantes que, após terminar o Ensino Médio, pensavam em como estudar para o vestibular, e resolveram fundar um cursinho de baixo custo no Clube das Mães do Brasil, ONG fundada pela mãe de um dos jovens e voltada para o atendimento de moradores de rua, oferecendo elementos para que eles possam superar a condição de pobreza, como cursos profissionalizantes em diversas áreas.

Os estudantes procuraram apoio para a realização do projeto, recorrendo ao cursinho APROVE e a outras pessoas. Além dos dois coordenadores, somou-se um terceiro, que trabalhava na APROVE como orientador profissional e militou por vários anos no movimento estudantil uspiano, ele auxiliou com informações necessárias ao funcionamento do cursinho.

As discussões para a configuração do projeto se deram no final do primeiro semestre de 1998. O cursinho iniciou suas aulas em agosto e foi até dezembro daquele mesmo ano. Na discussão do projeto, estabeleceu-se que ele seria pago; os professores, remunerados; e o serviço, de qualidade. Não haveria vínculos com o Clube das Mães do Brasil, que seria apenas responsável pela cessão do espaço e do nome. 
Localizado na região central de São Paulo, o recrutamento de alunos foi realizado através de panfletagem no metrô e de cartazes em ônibus. A seleção sócioeconômica de alunos ocorreu de forma precária, já que não existiam condições de conferir a documentação apresentada, mas segundo um dos coordenadores, ela não foi necessária, pois os candidatos eram visivelmente pobres e em número menor que o das vagas oferecidas, as quais totalizavam 90.

Os professores, em número de 16, foram chamados na véspera das aulas se iniciarem. A maioria deles já possuía experiência em cursinhos; outros davam aulas em colégios; e alguns eram estudantes universitários. Havia a expectativa de que estes últimos se formassem e compusessem um corpo estável de docentes para o cursinho. A remuneração era por aula dada, no valor de $\mathrm{R} \$ 12,00$, o docente não era registrado e não recebia nos feriados e faltas ocasionais. Os três coordenadores chegavam a receber no total R\$ 900,00 mensais; o mais experiente dos três recebia uma maior fatia desse bolo.

A verba do cursinho provinha das inscrições (o coordenador entrevistado não se lembrava do valor exato, se quinze ou vinte reais) e das mensalidades, no valor de $\mathrm{R} \$ 65,00$ (na época, quantia baseada em 50\% do salário mínimo). A cada mensalidade os estudantes recebiam uma apostila, que era comprada de um cursinho comercial a R\$ 33,00. Outras despesas advinham de fotocópias e material didático, e, em alguns casos, eram requeridas aos alunos contribuições voluntárias para auxiliar nas despesas.

O curso era oferecido no período noturno. Além das aulas baseadas nas apostilas, nas janelas abertas por falta eram discutidas questões relacionadas ao mercado de trabalho e à orientação profissional, pelo coordenador mais experiente. Eram estimuladas outras atividades, como projeção de vídeos e idas ao teatro, embora estas não constassem do programa inicial.

O cursinho encerrou suas atividades naquele mesmo ano de 1998. De acordo com o coordenador, vários fatores contribuíram para o término; um deles foi a evasão de alunos - após a primeira fase da FUVEST, menos de duas dezenas de estudantes continuaram a freqüentar as aulas; outro consistiu nas dificuldades criadas pelo Clube das Mães do Brasil, houve a perda da sala de aula e os diretores da ONG quiseram participar da administração financeira do cursinho. Após algumas reuniões, no ano de 1999, os coordenadores ficaram desestimulados a prosseguir com a atividade. 
Não foi realizado nenhum levantamento sobre o ingresso de estudantes em universidades. Informalmente se soube apenas de uma estudante que ingressou no Mackenzie.

\subsubsection{CAIS / AFROBRAS - Sociedade Afro-Brasileira de Desenvolvimento Cultural}

O cursinho CAIS foi organizado pela AFROBRAS- Sociedade Afro-Brasileira de Desenvolvimento Cultural -, e faria parte de um projeto mais amplo, que desenvolveria ações com o objetivo de "formação, informação, inserção, visibilidade, integração e valorização dos afrodescendentes" (Afrobras, s/data).

Este cursinho funcionou por poucos meses no ano de 1998, e as informações relacionadas a ele são escassas: uma reportagem da revista Isto É, a carta de uma "aluna-coordenadora" direcionada a Frei David (diretor da EDUCAFRO) e uma carta dos professores dirigida aos alunos. De acordo com a reportagem:

Em São Paulo, numa ampla casa com piscina, computadores e fax, o Cais oferece ainda aulas de natação, computação, inglês e espanhol. Com direito a cesta básica, vale-tranporte e mensalidade gratuita, o cursinho tem 180 alunos (1.520 se inscreveram) e espera que $70 \%$ deles sejam aprovados. Os mais carentes são selecionados. (Nascimento, 1 jul. 1998, p.59)

A "aluna-coordenadora" relata em sua carta que as aulas tiveram início em 19 de maio daquele ano e seguiram até o dia 7 de julho. No retorno do recesso de julho já não havia mais cursinho; os alunos depararam com uma carta demissionária dos professores e a dissolução do curso. A autora acusa ainda a AFROBRAS de ter criado um "mundo de mentiras", mas que, mesmo assim, o grupo continuou unido e estudando em outro local durante o segundo semestre de 1998.

Os nove professores que assinam a carta demissionária afirmam que não receberam nenhum pagamento relacionado às horas-aula ministradas, que a data de remuneração foi sendo prorrogada e associada à ocorrência de eventos que se reverteriam em renda para a AFROBRAS, mas que, mesmo após tais eventos, o pagamento não se efetuou. Eles também declaram sua intenção de procurar meios judiciais para a resolução do problema.

Infelizmente, não foi obtida nenhuma informação minuciosa sobre a atividade 
desenvolvida, o meio de sustentação, se era cobrada taxa de inscrição, qual o critério de seleção dos alunos, dentre outras. 
2.4 Quadro sinóptico dos cursinhos

\begin{tabular}{|c|c|c|c|c|c|c|c|c|c|}
\hline $\begin{array}{l}\text { Perfil } \\
\text { resumido do } \\
\text { cursinho }\end{array}$ & \begin{tabular}{|l|} 
Ano de \\
início
\end{tabular} & $\begin{array}{l}\text { No. de } \\
\text { vagas }\end{array}$ & $\begin{array}{l}\text { Taxa de } \\
\text { seleção }\end{array}$ & Taxas mensais & Critérios de seleção & $\begin{array}{l}\text { Vínculo dos } \\
\text { professores }\end{array}$ & Horário & Bairro/Local & \begin{tabular}{|l} 
Aulas ou espaços \\
pedagógicos diferenciados
\end{tabular} \\
\hline EDUCAFRO* & 1997 & \begin{tabular}{|l|}
1.000 \\
(estima- \\
tiva no \\
ano de \\
$1999)$
\end{tabular} & Não há. & $\begin{array}{l}\text { Até } 10 \% \text { do } \\
\text { salário mínimo; } \\
\text { alunos sem } \\
\text { condição não } \\
\text { pagam }\end{array}$ & $\begin{array}{l}\text { Ser afrodescendente, } \\
\text { estar a mais tempo } \\
\text { distante da escola e ser } \\
\text { carente. }\end{array}$ & $\begin{array}{l}\text { Voluntários. } \\
\text { Recebem vale } \\
\text { transporte e lanche. }\end{array}$ & $\begin{array}{l}\text { Varia por } \\
\text { núcleo. Aos } \\
\text { sábados, das } \\
* ; 00 \text { às } \\
18: 00 \text { hs., ou } \\
\text { período noturno } \\
\text { durante a } \\
\text { semana. }\end{array}$ & $\begin{array}{l}\text { Vários bairros/ } \\
\text { salões de igrejas, } \\
\text { paróquias, } \\
\text { comunidades } \\
\text { eclesiais de base, } \\
\text { escolas públicas } \\
\text { e particulares. }\end{array}$ & $\begin{array}{l}\text { Aulas de Cultura e } \\
\text { Cidadania com a mesma } \\
\text { carga horária das outras } \\
\text { disciplinas. }\end{array}$ \\
\hline $\mathrm{JOC}^{*}$ & 1996 & 90 & Não há. & $\begin{array}{l}\text { Até } 10 \% \text { do } \\
\text { salário mínimo }\end{array}$ & $\begin{array}{l}\text { Ser afrodescendente, } \\
\text { estar a mais tempo } \\
\text { distante da escola e ser } \\
\text { carente. }\end{array}$ & $\begin{array}{l}\text { Voluntários. } \\
\text { Recebem vale } \\
\text { transporte e lanche. }\end{array}$ & $\begin{array}{l}\text { Sábados, das } \\
\text { 9:00 às 18:00 } \\
\text { hs. }\end{array}$ & $\begin{array}{l}\text { Brás / } \\
\text { universidade } \\
\text { particular }\end{array}$ & $\begin{array}{l}\text { Aulas de Cultura e } \\
\text { Cidadania com a mesma } \\
\text { carga horária das outras } \\
\text { disciplinas. }\end{array}$ \\
\hline Paulo Freire* & 1997 & 210 & Não há. & $\mathrm{R} \$ 10,00^{*}$ & $\begin{array}{l}\text { Ter participado de } \\
\text { movimento social, } \\
\text { estar a mais tempo } \\
\text { distante da escola, ser } \\
\text { negro e mulher. }\end{array}$ & $\begin{array}{l}\text { Voluntários. } \\
\text { Recebem vale } \\
\text { transporte e lanche. }\end{array}$ & $\begin{array}{l}\text { Sábados, das } \\
\text { 8:00 às } \\
\text { 18:00hs. }\end{array}$ & Escola Pública & $\begin{array}{l}\text { Aula de Cidadania e } \\
\text { Cultura. }\end{array}$ \\
\hline $\begin{array}{l}\text { Alunos da } \\
\text { PUC-SP* }\end{array}$ & 1997 & 400 & Não há. & $\begin{array}{l}1.000 \text { folhas } \\
\text { sulfite na } \\
\text { matrícula }\end{array}$ & $\begin{array}{l}\text { Condição sócio- } \\
\text { econômica, ser } \\
\text { afrodescendente e } \\
\text { estar a mais tempo } \\
\text { distante da escola. }\end{array}$ & Voluntários. & $\begin{array}{l}\text { Sábados, das } \\
\text { 8:00 às 18:00 } \\
\text { hs. }\end{array}$ & $\begin{array}{l}\text { Sumaré / } \\
\text { universidade } \\
\text { particular }\end{array}$ & $\begin{array}{l}\text { Oficinas variadas em } \\
\text { julho. }\end{array}$ \\
\hline CAEH-USP* & 1998 & 60 & $\begin{array}{l}\text { Manual a } \\
\mathrm{R} \$ 2,00 \text { e } \\
\text { inscrição a } \\
\mathrm{R} \$ 35,00^{*}\end{array}$ & $\mathrm{R} \$ 60,00 *$ & $\begin{array}{l}\text { Condição sócio- } \\
\text { econômica (peso 2) e } \\
\text { prova de } \\
\text { conhecimentos (peso } \\
1 \text { ) }\end{array}$ & $\begin{array}{l}\text { Voluntários e } \\
\text { informais } \\
\text { remunerados por } \\
\text { hora-aula. }\end{array}$ & $\begin{array}{l}\text { Aulas durante a } \\
\text { semana no } \\
\text { período } \\
\text { noturno. }\end{array}$ & $\begin{array}{l}\text { Centro / Sede } \\
\text { alugada }\end{array}$ & Direitos Humanos. \\
\hline
\end{tabular}




\begin{tabular}{|c|c|c|c|c|c|c|c|c|c|}
\hline \begin{tabular}{|l} 
Perfil \\
resumido do \\
cursinho
\end{tabular} & \begin{tabular}{|l} 
Ano de \\
início
\end{tabular} & $\begin{array}{l}\text { No. de } \\
\text { vagas }\end{array}$ & $\begin{array}{l}\text { Taxa de } \\
\text { seleção }\end{array}$ & Taxas mensais & Critérios de seleção & \begin{tabular}{|l} 
Vínculo dos \\
professores
\end{tabular} & Horário & Bairro/ Local & \begin{tabular}{|l|} 
Aulas ou espaços \\
pedagógicos diferenciados
\end{tabular} \\
\hline $\begin{array}{l}\text { Grêmio da } \\
\text { Escola } \\
\text { Politécnica** }\end{array}$ & 1987 & 8.000 & $\begin{array}{l}\text { Manual a } \\
\mathrm{R} \$ 5,00 \text { e } \\
\text { inscrição a } \\
\mathrm{R} \$ 45,00\end{array}$ & $\mathrm{R} \$ 100,00$ & $\begin{array}{l}\left.\text { Vestibulinho ( } 1^{\mathrm{a}} \text {.fase }\right) \\
\text { e condiçãao sócio- } \\
\text { econômica (2 } 2^{\mathrm{a}} \text {.fase). }\end{array}$ & $\begin{array}{l}\text { Formal, com carteira } \\
\text { assinada. }\end{array}$ & $\begin{array}{l}\text { Turmas } \\
\text { diferenciadas: } \\
\text { matutino, } \\
\text { vespertino, } \\
\text { noturno e finais } \\
\text { de semana. }\end{array}$ & $\begin{array}{l}\text { Lapa / Sede } \\
\text { alugada }\end{array}$ & $\begin{array}{l}\text { Teatro amador, orientação } \\
\text { vocacional, núcleo de } \\
\text { cinema e vídeo, palestras } \\
\text { com personalidades } \\
\text { públicas, informações } \\
\text { sobre cursos e jornadas de } \\
\text { trajetória profissional. }\end{array}$ \\
\hline APROVE* & 1992 & 2000 & $\mathrm{R} \$ 30,00$ & $\begin{array}{l}\text { Até } 50 \% \text { do } \\
\text { salário mínimo }\end{array}$ & $\begin{array}{l}\left.\text { Vestibulinho ( } 1^{\mathrm{a}} \text {.fase }\right) \\
\text { e condição sócio- } \\
\left.\text { econômica ( } 2^{\mathrm{a}} \text { fase }\right) \text {. }\end{array}$ & $\begin{array}{l}\text { Formal, com carteira } \\
\text { assinada. }\end{array}$ & $\begin{array}{l}\text { Turmas } \\
\text { diferenciadas: } \\
\text { matutino, } \\
\text { vespertino, } \\
\text { noturno e finais } \\
\text { de semana. }\end{array}$ & $\begin{array}{l}\text { Butantã e Centro } \\
\text { / sede alugada }\end{array}$ & $\begin{array}{l}\text { Orientação vocacional, } \\
\text { semana cultural, eventos } \\
\text { de confraternização, } \\
\text { apresentação de filmes, } \\
\text { visitas monitoradas a } \\
\text { universidades e sistemas } \\
\text { de informação sobre } \\
\text { cursos. }\end{array}$ \\
\hline $\begin{array}{l}\text { Movimento } \\
\text { Humanista** }\end{array}$ & 1998 & 240 & $\mathrm{R} \$ 5,00$ & $\mathrm{R} \$ 5,00$ & \begin{tabular}{|l|} 
Ser aluno de escola \\
pública, ter participado \\
de movimento social, \\
disponibilidade para \\
auxílio na organização \\
do cursinho e \\
empenho no estudo.
\end{tabular} & Voluntários. & Aos sábados. & $\begin{array}{l}\text { Liberdade, Vila } \\
\text { Mariana, } \\
\text { Aclimação, } \\
\text { Sapopemba e } \\
\text { Saúde / sede do } \\
\text { MH, sindicato, } \\
\text { escola pública e } \\
\text { entidade religiosa }\end{array}$ & $\begin{array}{l}\text { Orientação vocacional e } \\
\text { tarefas na organização do } \\
\text { cursinho. }\end{array}$ \\
\hline
\end{tabular}




\begin{tabular}{|c|c|c|c|c|c|c|c|c|c|}
\hline $\begin{array}{l}\text { Perfil } \\
\text { resumido do } \\
\text { cursinho }\end{array}$ & $\begin{array}{l}\text { Ano de } \\
\text { início }\end{array}$ & $\begin{array}{l}\text { No. de } \\
\text { vagas }\end{array}$ & $\begin{array}{l}\text { Taxa de } \\
\text { seleção }\end{array}$ & Taxas mensais & Critérios de seleção & $\begin{array}{l}\text { Vínculo dos } \\
\text { professores }\end{array}$ & Horário & Bairro/ Local & $\begin{array}{l}\text { Aulas ou espaços } \\
\text { pedagógicos diferenciados }\end{array}$ \\
\hline IAPSI* & 1999 & 300 & $\mathrm{R} \$ 35,00$ & $\mathrm{R} \$ 65,00$ & $\begin{array}{l}\text { Vestibulinho }\left(1^{\mathrm{a}} \text {.fase }\right) \\
\text { e condição sócio- } \\
\text { econômica }\left(2^{\mathrm{a}} \text {.fase }\right)\end{array}$ & $\begin{array}{l}\text { Informal. } \\
\text { Remuneração por } \\
\text { hora-aula. }\end{array}$ & $\begin{array}{l}\text { Noturno, com } \\
\text { aulas aos } \\
\text { sábados. }\end{array}$ & Butantã / USP & $\begin{array}{l}\text { Orientação Vocacional, } \\
\text { teatro, palestras e aulas de } \\
\text { Tai-chi-chuan. }\end{array}$ \\
\hline $\begin{array}{l}\text { Thema } \\
\text { Educação** }\end{array}$ & 1998 & 150 & $\begin{array}{l}\text { Manual a } \\
\mathrm{R} \$ 4,50\end{array}$ & $\begin{array}{l}\text { Até } 10 \% \text { do } \\
\text { salário mínimo }\end{array}$ & $\begin{array}{l}2 \text { questionários e uma } \\
\text { prova. }\end{array}$ & Voluntários. & $\begin{array}{l}\text { Noturno, com } \\
\text { aulas aos } \\
\text { sábados. }\end{array}$ & Tucuruvi & $\begin{array}{l}\text { Aulas de Cidadania e } \\
\text { Orientação vocacional. }\end{array}$ \\
\hline AEUSP* & 1998 & 120 & $\mathrm{R} \$ 30,00$ & $\mathrm{R} \$ 40,00$ & $\begin{array}{l}\text { Condição sócio- } \\
\text { econômica, entrevista } \\
\text { e redação. }\end{array}$ & $\begin{array}{l}\text { Informal, com } \\
\text { remuneração fixa. }\end{array}$ & & Butantã e Jaguaré & $\begin{array}{l}\text { Oficinas temáticas com } \\
\text { horário fixo. }\end{array}$ \\
\hline $\begin{array}{l}\text { Núcleo de } \\
\text { Consciência } \\
\text { Negra* }\end{array}$ & 1994 & 140 & $\mathrm{R} \$ 60,00$ & $\mathrm{R} \$ 60,00$ & $\begin{array}{l}70 \% \text { de } \\
\text { afrodescendentes, } \\
\text { vestibulinho e } \\
\text { condição sócio- } \\
\text { econômica. }\end{array}$ & $\begin{array}{l}\text { Informal, com } \\
\text { remuneração por } \\
\text { hora-aula. }\end{array}$ & $\begin{array}{l}\text { Noturno, com } \\
\text { aulas aos } \\
\text { sábados. }\end{array}$ & Butantã / USP & $\begin{array}{l}\text { Aulas de Cidadania e } \\
\text { Consciência negra. }\end{array}$ \\
\hline XI de Agosto* & 1996 & 300 & \begin{tabular}{l|} 
Manual a \\
$\mathrm{R} \$ 3,00$ e \\
inscrição a \\
$\mathrm{R} \$ 42,00$
\end{tabular} & $\mathrm{R} \$ 55,00$ & $\begin{array}{l}\text { Vestibulinho }\left(1^{\mathrm{a}} \text {.fase }\right) \\
\text { e condição sócio- } \\
\text { econômica }\left(2^{\mathrm{a}} \text {.fase }\right) \text {. }\end{array}$ & $\begin{array}{l}\text { Informal, com } \\
\text { remuneração por } \\
\text { hora-aula. }\end{array}$ & $\begin{array}{l}\text { Diurno e } \\
\text { noturno. }\end{array}$ & $\begin{array}{l}\text { Centro / sede } \\
\text { alugada }\end{array}$ & $\begin{array}{l}\text { Orientação vocacional, } \\
\text { aulas de Cidadania } \\
\left(1^{\circ} \text {.semestre }\right) \text { e culturas e } \\
\text { artes }\left(2^{\circ} \text {.semestre }\right) .\end{array}$ \\
\hline $\mathrm{CAVC}^{* *}$ & 2000 & 140 & $\mathrm{R} \$ 40,00$ & $\mathrm{R} \$ 70,00$ & $\begin{array}{l}\text { Vestibulinho }\left(1^{\mathrm{a}} \text {.fase }\right) \\
\text { e condição sócio- } \\
\text { econômica }\left(2^{\mathrm{a}} \text {.fase }\right)\end{array}$ & $\begin{array}{l}\text { Informal, com } \\
\text { remuneração por } \\
\text { hora-aula. }\end{array}$ & $\begin{array}{l}\text { Noturno, com } \\
\text { aulas aos } \\
\text { sábados. }\end{array}$ & Butantã / USP & $\begin{array}{l}\text { Visitas ao teatro e palestras } \\
\text { sem horário definido. }\end{array}$ \\
\hline $\begin{array}{l}\text { Alunos da } \\
\text { Química } \\
\text { USP** }\end{array}$ & 2000 & 160 & $\mathrm{R} \$ 25,00$ & $\mathrm{R} \$ 50,00$ & Não há. & $\begin{array}{l}\text { Voluntários e } \\
\text { informais } \\
\text { remunerados por } \\
\text { hora-aula. }\end{array}$ & Noturno & Butantã / USP & $\begin{array}{l}\text { Visita monitorada aos } \\
\text { laboratórios do IQUSP. }\end{array}$ \\
\hline $\begin{array}{l}\text { Clube das } \\
\text { Mães do Brasil }\end{array}$ & 1998 & 90 & $\begin{array}{l}\mathrm{R} \$ 15,00 \mathrm{a} \\
\mathrm{R} \$ 20,00\end{array}$ & $\mathrm{R} \$ 65,00$ & $\begin{array}{l}\text { Condição sócio- } \\
\text { econômica. }\end{array}$ & $\begin{array}{l}\text { Informal, com } \\
\text { remuneração por } \\
\text { hora-aula. }\end{array}$ & Noturno & Centro & $\begin{array}{l}\text { Discussões nas janelas dos } \\
\text { professores, idas ao teatro } \\
\text { e projeção de vídeos. }\end{array}$ \\
\hline
\end{tabular}

* informações de 1999

** informações de 2000 


\subsection{Analisando algumas características dos pré-vestibulares alternativos}

Algumas características dos cursinhos pesquisados, bem como uma melhor compreensão de suas atividades, motivações e formas de organização são elementos presentes neste tópico.

Não se estabeleceu uma classificação, mas procurou-se abordar aspectos que diferenciem e agrupem os pré-vestibulares, sem que isso recaia sobre um rótulo. Foi bastante comum, entre os dirigentes de cursinho, a utilização do termo "comunitário" para classificar aqueles que contam com professores voluntários e salas de aula emprestadas gratuitamente. Desta forma, os outros seriam "alternativos" ou "sem fins lucrativos". Tal modelo separava os cursinhos oriundos do movimento negro, agrupava alguns do movimento estudantil, que afirmavam não possuir qualquer identificação, mostrando-se bastante insatisfatório. Relatar suas semelhanças e diferenças através de diversos tópicos foi a forma encontrada para driblar a classificação.

\subsubsection{Origem e projeto político-pedagógico}

As agremiações e os coordenadores individuais que patrocinam os cursinhos acabam sendo decisivos na elaboração do projeto político-pedagógico. Boa parte pode ser localizada em dois movimentos de caráter mais geral: o estudantil e o negro. Entretanto, verificou-se a existência de outros, como o Movimento Humanista, a Juventude Operária Católica, o Clube das Mães do Brasil e a APROVE.

Há também os inúmeros apoios indiretos de outros setores da sociedade, como Sociedades Amigos de Bairro, universidades e escolas - sejam elas públicas ou particulares -, igrejas, empresas etc. Esta diversidade de instituições envolvidas reflete a preocupação de toda a sociedade com a democratização do acesso ao Ensino Superior, não se restringindo somente aos envolvidos diretamente com a universidade (estudantes), bem como a um grupo que historicamente luta pela sua inclusão nessa etapa educacional (negros).

Como principal modelo do movimento estudantil destaca-se o Cursinho da Poli, o primeiro a surgir, organizado por alunos. Seus coordenadores o 
proclamam como uma "referência" para o movimento estudantil na luta pela democratização do Ensino Superior. Sua influência é claramente percebida, como no curso preparatório dos Alunos da Psicologia-USP. Talvez suas principais características, assimiladas por outros cursinhos, sejam a cobrança de mensalidades, a remuneração de seus docentes e o vestibulinho como forma de seleção dos alunos.

No movimento negro, a Cooperativa Educacional Steve Biko, localizada na Bahia, trouxe, como principais influências, as aulas de Cidadania e uma atenção especial à questão do negro no Ensino Superior brasileiro, projeto que possui características muito semelhantes às do cursinho do Núcleo de Consciência Negra e a EDUCAFRO. Esta última ainda apresentou uma grande inovação, com a adoção de professores voluntários e uma mensalidade baseada no salário mínimo. Foram os cursinhos com origem no Movimento Negro que elaboraram as primeiras propostas de cotas e isenção de taxas de inscrição.

Essas três organizações (NCN, Steve Biko e EDUCAFRO), serviram de modelo para outras organizações do movimento negro que surgiram posteriormente, embora essas também tenham incorporado outras formas de atuação e possuam uma reflexão própria sobre a questão do negro no Ensino Superior.

Detectaram-se alguns níveis de atuação nas diversas propostas, assim agrupados:

- o oferecimento do pré-vestibular a pessoas sem condições financeiras de cursar um cursinho comercial, para que possam disputar uma vaga nas melhores universidades em condição de igualdade;

- atendimento aos grupos sistematicamente excluídos dos bancos universitários;

- dotar o aluno de elementos que o auxiliem a lidar com dificuldades que irá encontrar no seu cotidiano;

- incorporar no aluno uma visão questionadora da sociedade em que vive, procurando abordar e discutir temas que não estariam presentes numa educação escolar tradicional; 
- realizar uma intervenção no vestibular procurando democratizá-lo e reduzir as desigualdades no Ensino Superior;

Pode-se dizer que a primeira das propostas citadas é comum a todos os pré-vestibulares alternativos, sendo que alguns a têm como único objetivo. $\mathrm{O}$ cursinho do Clube das Mães do Brasil pode ser tomado como um exemplo. Montado por iniciativa de estudantes de Ensino Médio, procurou abrir espaço prioritariamente para estudantes que não teriam condições de pagar um cursinho comercial.

O atendimento a pessoas com menor representação nos bancos universitários é mais visível naqueles cursinhos com recorte racial. Mas existem também reservas de vagas para outros grupos com perfis diferenciados. No cursinho da Poli foi aberto espaço para ex-presidiários e ex-internos da Febem; a EDUCAFRO dá preferência a pessoas que perderam o contato com o estudo há muitos anos. Essa proposta se distinguiria do atendimento àqueles com menor renda, reconhecendo que, além do obstáculo econômico, para alguns, outros elementos compõem o fator de exclusão.

A efetivação da terceira proposta pode ser observada, como exemplo, no estímulo aos estudantes para assumir a organização das atividades dos prévestibulares ou criar formas de arrecadação de dinheiro para o pagamento das despesas do cursinho e do vestibular. Assim, a criação de certa autonomia nos estudantes seria uma das tarefas educacionais.

A discussão de temas ausentes na educação escolar tradicionalmente oferecida ocorreria nas aulas de cidadania, direitos humanos, cultura e em outros espaços pedagógicos. É evidente que a mera existência de matérias não vinculadas diretamente à atividade propedêutica não garante que este objetivo seja alcançado; seria necessário observar o conteúdo de cada uma dessas matérias e a forma como ela é ministrada. A inclusão de disciplinas específicas é uma estratégia antiga; no sistema escolar brasileiro as matérias de Educação Moral e Cívica e Organização Social e Política Brasileira foram incluídas também com o objetivo de afirmar determinado ponto de vista. 
Já a alteração da seleção universitária, visando maior igualdade no ingresso, depende de uma ação direta junto aos organizadores dos vestibulares e legisladores. A proposição de novos modelos pode incluir, por exemplo, a adoção de cotas, a isenção de taxas do exame e modificações de conteúdo.

A complexidade de cada proposta elaborada irá influenciar os outros itens de análise separados abaixo.

\subsubsection{Critérios de seleção do alunado}

A observação dos critérios de seleção adotados por cada cursinho alternativo é uma etapa importante de análise, pois é justamente quando os organizadores se deparam com as mesmas dificuldades daqueles que realizam os exames vestibulares. Quais regras devem ser adotadas para excluir ou incluir um aluno? Embora em etapas e atividades diferenciadas, vale pensar o quanto as soluções utilizadas poderiam ser aplicadas ou adaptadas para a seleção dos alunos universitários. É também na reformulação dos critérios de seleção que se expressa um questionamento de valores tão arraigados, como o mérito, e ocorre a disseminação de novos modelos.

Aqueles que optaram pela adoção de uma prova de conhecimentos (vestibulinho) dificilmente o fazem como única etapa de seleção; ela pode ser utilizada num primeiro momento ou combinada com algum outro critério. Caso isso ocorresse, talvez se desvirtuasse a proposta de atendimento de pessoas desfavorecidas economicamente, pois seu efeito seria semelhante ao do vestibular, com as primeiras colocações ocupadas por aqueles de perfil semelhante aos aprovados nos cursos mais concorridos. Entretanto se o vestibulinho é aplicado em grande escala - como no caso do Cursinho da Poli em 1999, com cerca de 15.000 candidatos para 850 vagas - a posterior seleção econômica entre os melhores colocados pode ser nula, pois os mais carentes já teriam sido excluídos.

Por outro lado, a adoção de testes de conhecimento pode refletir numa maior taxa de aprovação, uma vez que a população selecionada já teria mais conhecimentos acumulados. Esta forma de seleção é mais adotada entre aqueles 
que possuem como origem o movimento estudantil, talvez porque os próprios coordenadores tenham sido aprovados no vestibular da FUVEST e considerarem este um elemento importante na seleção.

A escolha por atender os candidatos com maior dificuldade pode ocasionar um efeito perverso no resultado do vestibular, já que há um percurso maior a percorrer para a absorção do conteúdo e o tempo de preparo é semelhante.

Alguns cursinhos optam por uma avaliação em vez da seleção, e, para não terem problemas de excesso de candidatos que poderia inviabilizar este tipo de seleção, realizam uma divulgação localizada, junto ao público-alvo do cursinho.

A opção pela inclusão preferencial do aluno negro acaba sendo restrita apenas aos que têm entre seus coordenadores pessoas vinculadas ao movimento negro, embora nem todos esses cursinhos adotem tal critério, como a seleção encontrada no Thema.

A participação em movimentos sociais como elemento de seleção aparece no pré-vestibular do Movimento Humanista e no Paulo Freire. No primeiro espera-se que o aluno auxilie na organização, e no segundo, que contribua nas discussões em sala de aula e continue a exercer atividades em conjunto com os coordenadores.

\subsubsection{Aulas especiais}

Para algumas das atividades oferecidas, como apresentação de vídeos, sistema de informação sobre vestibulares ou orientação vocacional - que também poderiam estar presentes em cursinhos comerciais -, não se registrou nenhuma explicação mais elaborada para sua inclusão, como se fossem indissociadas da atividade de preparação para os exames vestibulares.

Espaços como aulas de cidadania, consciência negra, direitos humanos e cultura normalmente estão vinculados aos objetivos dos cursinhos que visam outro tipo de formação educacional que não apenas a propedêutica.

Vários temas são explorados nessas aulas, como: prevenção à AIDS e DSTs, Declaração Universal dos Direitos Humanos, discriminação racial, 
Movimento dos Sem-Terra, globalização, dentre outros. Os temas eleitos, normalmente, estão associados ao projeto de cada cursinho. Assim, a EDUCAFRO e o NCN privilegiam temas vinculados à negritude, enquanto o XI de agosto e CAEHUSP exploram outras vertentes, como direitos humanos.

A organização dessas aulas é diversa, em alguns pré-vestibulares elas são mais sistematizadas, com currículo, professores e carga horária fixos; em outros elas podem ocorrer de forma sistemática, mas com palestrantes diversos; e há também casos em que elas são oferecidas nas janelas das aulas regulares.

Não se trata apenas de um curso de atualidades, a expectativa é que nesses espaços os alunos reflitam e produzam questionamentos sobre os problemas da sociedade, que dificilmente são incluídos nos currículos escolares.

\subsubsection{O curso propedêutico}

Verificaram-se dois modelos básicos de funcionamento: um trabalha com apostila e professor remunerado, e o outro tem professor voluntário, aula semanal e material didático selecionado pelos integrantes.

Naqueles que utilizam apostilas, elas podem ser de confecção própria ou comprada de pré-vestibulares comerciais. Alguns ainda estabeleceram convênios com os comerciais, como o cursinho dos alunos da Psicologia da USP, que tem assistência pedagógica para seus professores, ou o XI de Agosto, que tem alguns professores que ministram aulas no mesmo cursinho do qual compram as apostilas, e cujos aprovados são incluídos nas estatísticas do cursinho comercial. As aulas eram ministradas em períodos inteiros.

$\mathrm{Na}$ ocasião de professores voluntários, praticamente não havia nenhum material de estudo mais sistematizado; normalmente este era fotocopiado de uma aula para outra; às vezes empregando como matrizes as apostilas de cursos comerciais ou livros didáticos. Nesses casos, o aluno normalmente possuía apenas uma aula de cada disciplina por semana, que podia ser ministrada no período noturno de segunda a sexta ou nos sábados durante todo o período. Neste modelo de funcionamento, parece claro que haverá certa dificuldade de o 
professor abordar todo o conteúdo do vestibular em tão pouco tempo e com um material não sistematizado.

\subsubsection{Professores e coordenadores}

O vínculo dos professores e coordenadores é variável; em alguns cursinhos eles são voluntários e em outros pode haver remuneração e até registro em carteira profissional. Isso acabará por surtir diferenças na qualidade e no preço do ensino, pois o sistema de voluntariado acaba se restringindo a poucas aulas. Normalmente isso ocorre nos cursinhos de final de semana ou nos que possuem apenas algumas aulas durante a semana.

O trabalho voluntário é assim entendido por Marília Spósito:

Enquanto categoria sociológica a ação voluntária é aquela que implica 'adesão livre a uma forma de solidariedade coletiva e o pertencimento a uma rede de relações da qual se participa por escolha'. A gratuidade dos serviços ofertados revela o fato de que os benefícios econômicos não constituem a base da relação entre os que participam. Como qualquer relação social não estão desconhecidas as possíveis retribuições simbólicas, de prestígio, autoestima e poder presentes na ação voluntária.

A ação voluntária envolveria o altruísmo, a responsabilidade exprimindo uma modalidade de participação nos problemas do mundo, sobretudo diante dos que são excluídos, daqueles que sofrem ou são privados de alguns recursos. Seu fundamento, recoberto pela idéia do dom, explicita uma dimensão simbólica que diz respeito à pergunta, muitas vezes insurgente, "por que ocupar-se com o outro?" Quando as relações dominantes estão marcadas estritamente pela lógica do interesse ou utilitarismo, esse tipo de indagação aponta um campo de conflitos importantes em torno de valores antagônicos. (Spósito, 1999)

Assim, caberia um outro estudo, mais qualitativo, que abordasse as diferentes motivações dos professores para a adesão voluntária a um projeto de cursinho pré-vestibular alternativo, o que não fez parte dos objetivos deste trabalho.

Presenciaram-se ainda casos mistos, no CAEHUSP e no cursinho dos alunos da Química-USP, em que existiam professores remunerados, e outros, nos quais os coordenadores ainda assumiam algumas aulas gratuitamente. No NCN o pagamento é bastante irregular, entretanto os professores são em sua maioria 
simpatizantes do projeto ou mesmo ex-alunos e acabam compreendendo o atraso no pagamento com relativa facilidade.

Os cursinhos mais estruturados - como o da Poli e a APROVE - chegam a ter vários professores com experiência em pré-vestibulares comerciais.

Os professores estudantes são maioria nos cursos organizados pelo movimento estudantil. Pode-se pensar que este seja o início de sua atividade profissional, com obtenção de experiência e renda.

Uma atividade desenvolvida por jovens que gera renda e experiência para eles, assemelha-se a experiências relatadas por Spósito nas quais os jovens desenvolvem formas associativas que ultrapassam os marcos tradicionais da relação assalariada.

Quando é oferecida remuneração, o valor da hora-aula fica em torno de dez a quinze reais, sendo superior ao pago na rede estadual paulista, embora nem sempre haja garantia dos direitos trabalhistas. Vários coordenadores, que são ainda estudantes, também recebem pelo trabalho.

Nos cursinhos mais distantes do centro da cidade, como o núcleo da EDUCAFRO em Cidade Tiradentes, quase não havia professores qualificados, nem mesmo estudantes universitários. A maior parte das aulas ficava ao encargo dos próprios alunos. Em contraposição a essa experiência, o pré-vestibular Paulo Freire demonstrou possuir o corpo docente mais qualificado, com pessoas matriculadas em cursos de mestrado e doutorado na USP, e que optaram pelo oferecimento do curso na periferia.

O perfil dos coordenadores é variável e normalmente está associado à origem do cursinho. Naqueles organizados por centros acadêmicos e grêmios estudantis, por exemplo, os coordenadores são quase sempre dirigentes dessas entidades ou alunos dos respectivos cursos universitários; alguns alunos, mesmo depois de formados, ainda continuam vinculados ao pré-vestibular.

Há também militantes do Movimento Negro espalhados em vários cursinhos, como Thema, Núcleo de Consciência Negra, Alunos da PUC-SP, Paulo Freire e EDUCAFRO, que compõem um perfil mais bem definido de coordenador. 
Exceto esses dois casos, o coordenador assume características variadas e de difícil definição, mesmo naqueles cursos organizados e dirigidos pelo movimento negro. Na EDUCAFRO, por exemplo, pode-se encontrar nos núcleos estudantes universitários ou integrantes de comunidades religiosas que pouco têm em comum além dessa atividade.

\subsubsection{Local e bairro}

Percebeu-se uma grande concentração de oferecimento dos prévestibulares na Zona Oeste do Município. Ali estavam a APROVE, o cursinho da Psicologia da USP, o da AMORCRUSP, o do NCN, o da Poli e dos Alunos da PUC-SP. Talvez tal concentração tenha ocorrido motivada pela presença do movimento estudantil na organização de alguns cursinhos, bem como uma certa facilidade na obtenção de salas de aula ociosas nas universidades ali localizadas.

Por sua vez, a EDUCAFRO mostrou-se presente nos bairros mais periféricos e carentes, como Cidade Tiradentes, Capão Redondo e Jardim Ângela. Isso foi facilitado pelo vínculo com a Igreja Católica, pois vários dos locais em que seus núcleos funcionavam eram espaços pertencentes a essa instituição, como Comunidades Eclesiais de Base e salões de igrejas.

A localização de cursinhos em bairros mais distantes do centro da cidade talvez auxilie no atendimento de um público mais carente e contribua para a concretização da proposta de atendimento preferencial a essas pessoas. O único cursinho que demonstrou ter refletido sobre isso foi o Paulo Freire, que, mesmo com seus membros vinculados à USP, optou por ministrar as aulas num bairro distante do centro.

\subsubsection{Demanda e expansão}

Durante toda a década de 1990, observou-se o aparecimento de inúmeras propostas de pré-vestibulares alternativos com vistas ao atendimento de uma população que não possuía condições financeiras de optar por um curso comercial. Este fenômeno pode ser observado na Tabela 13: 
Tabela 13: Número de cursinhos pré-vestibulares alternativos existentes por ano no Município de São Paulo.

\begin{tabular}{|l|c|}
\hline Ano & $\begin{array}{c}\text { Cursinhos } \\
\text { existentes }\end{array}$ \\
\hline 1991 & 1 \\
\hline 1992 & 2 \\
\hline 1993 & 2 \\
\hline 1994 & 3 \\
\hline 1995 & 3 \\
\hline 1996 & 5 \\
\hline 1997 & 8 \\
\hline 1998 & 13 \\
\hline 1999 & 13 \\
\hline 2000 & 15 \\
\hline
\end{tabular}

Além disso, pôde-se observar que vários cursinhos multiplicaram suas vagas durante o período estudado. O caso mais notável é o do Cursinho da Poli, que iniciou suas atividades com o oferecimento de 60 vagas em 1987, chegando a 850 em 1999, e no ano seguinte chegou a comportar 8.000 alunos.

Se esse crescimento foi mais presente naquele cursinho, vários outros podem ser citados, como a APROVE - com 35 vagas em 1992 e 850 em 1999 -, o NCN - que iniciou com 60 estudantes e chegou a 140 no ano de 2000. Infelizmente não se conseguiu traçar um quadro fiel que retratasse esse crescimento, pois em alguns casos a própria coordenação não tinha o controle sobre as vagas de cada núcleo; mas fica evidente a expansão destas também.

Provavelmente o que impulsionou o crescimento foi a expansão do Ensino Médio nesse mesmo período e a importância da educação superior para a obtenção de melhor renda e emprego.

O Cursinho da Poli, que teve até 1999 boa parte de seu financiamento ancorado na taxa de inscrição dos candidatos a uma vaga, talvez tenha sido o primeiro a perceber a enorme demanda existente por um cursinho com preço acessível a uma outra camada da população. Esmerando-se na atividade de divulgação de seus processos seletivos, chegou a obter dez vezes mais candidatos do que o número de vagas existentes, fator que impulsionou sua expansão. 


\subsubsection{Taxas de inscrição e mensalidade}

O pré-vestibular organizado pelos alunos da PUC-SP é o único que não arrecada dinheiro para seu funcionamento, recebendo uma cota de folhas de papel no início do ano, transformada, posteriormente, em pagamento das fotocopiadoras que reproduzirão seu material didático. Funcionando com professores voluntários e em espaço cedido no prédio da própria universidade, não há qualquer tipo de despesa.

Os outros que funcionam também com professores voluntários cobram uma taxa mensal bastante reduzida. Em alguns casos ela é referenciada em uma porcentagem do salário mínimo. Esse valor é revertido em auxílio aos professores e para a fotocópia de algum material didático ou administrativo. É importante ressaltar que alguns coordenadores reclamaram que estudantes ficavam inadimplentes por não terem dinheiro para arcar com essa taxa, e outros simplesmente se omitiam do pagamento.

Há uma clara distinção entre esses cursinhos e aqueles que remuneram os professores e adotam apostilas, acumulando despesas e tendo necessidade de cobrar mensalidades e taxas de inscrição em valores bem superiores. Eles acabam por atender a uma parcela da população também pobre, mas em melhor condição de vida.

Em alguns casos, o pagamento da mensalidade também contribuiu para a estruturação de outras atividades. Assim, o Núcleo de Consciência Negra conseguiu a contratação de uma secretária e o CAEHUSP possibilitou o pagamento do aluguel de sua sede.

O cursinho da Poli é aquele que apresentou as maiores taxas; entretanto, no balanço publicado no ano de 2001, percebe-se um grande déficit nos anos de 1999 e 2000, e uma projeção para o ano de 2001 de um déficit de R\$ 2.200.000,00 (dois milhões e duzentos mil reais). Trabalhando sempre no vermelho, vale perguntar como pôde se sustentar por tantos anos.

Essa atividade, como tantas outras, também pode se associar a objetivos escusos; embora não estivesse incluso na amostra por ter projetado seu início para o ano de 2001, vale citar o cursinho ancorado na Fundação para o 
Desenvolvimento das Artes e Comunicações associada à Escola de Comunicações e Artes da USP. Prometendo aulas em quatro períodos e locais distintos, arrecadou cerca de $\mathrm{R} \$ 9.000$ (nove mil reais), relacionados à inscrição. As aulas nunca ocorreram e a fundação negou ter qualquer relação com o cursinho. (Cafardo, 29 ago. 2001)

Alguns cursinhos chegam a replicar o modelo dos vestibulares, cobrando a venda de manual, taxa de inscrição, e posteriormente um processo seletivo de ingresso. A cobrança da taxa e de mensalidades será importante na discussão sobre a isenção da taxa do vestibular, pois em alguns casos estas superam o valor da inscrição dos vestibulares das universidades públicas paulistas.

\subsection{9 Índices de aprovação}

Outro elemento pelo qual se pode avaliar os cursinhos é o seu índice de aprovação nos principais vestibulares; ou seja, naqueles que garantem o ingresso nas universidades públicas, já que essa é uma meta estabelecida pelos próprios cursinhos alternativos.

Nem todos os coordenadores detinham essa informação, seja porque não dispunham de meios para entrar em contato com seus antigos alunos ou porque o cursinho deixou de funcionar logo após o primeiro ano de experiência (como foi o caso dos Alunos da Química USP). Muitos números apresentados também não vieram acompanhados do método utilizado para obtê-lo; assim a qualidade da informação ficou bastante prejudicada. Apenas quatro cursinhos apresentaram dados mais consistentes sobre o desempenho dos alunos em vestibulares: Thema, CAVC, AEUSP e IAPSI.

O Thema, no ano 2000, registrou 38 alunos inscritos em vestibulares de universidades públicas paulistas, sendo 8 aprovados, o que equivale a $21 \%$ daquele total. O cursinho oferecido pelos alunos da Psicologia USP conseguiu aprovar 23 pessoas no ano de 1999 e 33 no ano posterior. O CAVC teve no ano 2000 cerca de 5 alunos aprovados; e os coordenadores da AEUSP disseram que 3 de seus alunos ingressaram no ano de 1998. 
Esses números são aparentemente restritos, todavia é preciso recordar que esses cursinhos trabalham com alunos com um perfil que normalmente é desfavorecido no ingresso, além disso, apresentam corpo docente muitas vezes inexperiente (com vários estudantes universitários) e orçamento reduzido. Assim, diante das dificuldades existentes, é possível dizer que cada aprovação ocorrida em vestibulares extremamente concorridos como os que regulam a entrada para USP, Unicamp e Fuvest, constitui-se num sucesso do projeto realizado.

Para aumentar as possibilidades de aprovação de seus estudantes, os cursinhos se uniram em Fórum e passaram a reivindicar políticas de isenção de taxas e ações afirmativas.

\subsection{Fórum dos cursinhos alternativos e comunitários de São Paulo}

O Fórum nasceu no ano de 2000, reunindo grande parte dos cursinhos do Estado de São Paulo, a partir da necessidade de reivindicação conjunta de alguns tópicos junto às fundações organizadoras de vestibulares.

Apenas um documento específico sobre o Fórum foi localizado; nele os cursinhos afirmam que todos têm direito à educação superior pública, gratuita e de qualidade. As poucas vagas existentes neste ensino, associadas à má qualidade da educação básica pública, seriam responsáveis pela existência dos cursinhos. Eles seriam um dos "sintomas mais evidentes da precariedade do nosso sistema educacional público". (Iapsi, 22 set. 2001b)

Procurando reverter a exclusão dos alunos da rede pública, os prévestibulares alternativos afirmam ter elegido o aluno da rede pública como alvo preferencial. O Fórum declarou os seguintes objetivos:

- Favorecer o reconhecimento da educação pública, gratuita e de qualidade como um direito inalienável de todos os cidadãos, lutando, portanto, pelo fim da necessidade dos cursinhos;

- buscar não só a entrada, mas também a permanência de estudantes de baixa-renda na universidade, lutando pela ampliação de vagas nas universidades, em especial os noturnos, mais bolsas-trabalho e alimentação, mais vagas nos conjuntos residenciais universitários, entre outros; 
- favorecer o reconhecimento dos cursinhos alternativos e comunitários como medidas paliativas, que têm o potencial de solucionar, em curto prazo, o problema de poucos estudantes;

- resgatar os processos históricos, sociais e políticos que produziram o atual sucateamento do ensino público, reconhecendo o papel estrutural das políticas públicas educacionais;

- priorizar a participação efetiva dos estudantes dos cursinhos alternativos e comunitários nas discussões e lutas do Fórum, trabalhando em conjunto para a apropriação dessas conquistas como fruto de muitos debates $\mathrm{e}$ reivindicações. (Iapsi, 22 set. 2001b)

Não se encontra no documento uma posição sobre cotas para alunos de escolas públicas ou para negros, mostrando que não há consenso sobre esses pontos; entretanto, outras ações afirmativas, como isenção de taxas e cursinhos voltados para uma população com menores recursos financeiros, estão presentes.

A reunião em Fórum permitiu que algumas reivindicações fossem realizadas de forma coletiva, como será visto no capítulo seguinte. 


\section{CAPÍTULO 3 - Para além do oferecimento do cursinho: a busca pela democratização do acesso.}

Neste capítulo reúnem-se as diversas manifestações que objetivaram uma maior democratização no acesso aos bancos universitários e suas possíveis conseqüências.

O vestibular organizado pela FUVEST, por oferecer maior número de vagas públicas no Município de São Paulo e sofrer mais diretamente as pressões exercidas pelo grupo de cursinhos estudado, foi privilegiado nas observações. Optou-se também por observar o comportamento da USP como detentora da maior parte dessas vagas.

As reivindicações e propostas feitas pelos alternativos para a transformação do vestibular foram várias, destacando-se a luta pela isenção da taxa de inscrição, a reserva de vagas para alunos da rede pública, ações afirmativas para garantir o acesso da população negra, a gratuidade do ENEM e o ingresso como alunos especiais nas públicas. Tais reivindicações aconteceram em passeatas, reuniões e várias ações judiciais que envolveram a USP, FUVEST e até o Ministério da Educação. Na seqüência algumas dessas reivindicações e seus desdobramentos são descritos.

\subsection{A isenção da taxa do vestibular da FUVEST}

Os atuais dirigentes da FUVEST relatam que candidatos, individualmente, ou acompanhados de seus familiares, procuravam seus antecessores, alegando não ter condições de arcar com a despesa da inscrição. Comenta-se que alguns diretores, quando abordados, chegavam a se solidarizar e pagar o valor de seu próprio bolso. Obviamente esta "solução" deixou de ser viável quando os indivíduos foram substituídos por grupos organizados.

O diretor geral da EDUCAFRO, Frei David Raimundo dos Santos, já tinha no Estado do Rio de Janeiro ampla experiência na luta pela isenção da taxa do vestibular, o que se dava através de ações judiciais do Pré-Vestibular para Negros 
e Carentes. Quando da sua transferência para São Paulo, em 1997, praticamente não havia qualquer movimento reivindicatório neste sentido.

A luta pela isenção concretizou-se através de variadas formas; reuniões entre coordenadores dos cursinhos alternativos e diretores da FUVEST, manifestações na porta da fundação e diversas ações judiciais.

Em levantamento realizado pela Consultoria Jurídica da USP das ações judiciais no período de 1997 a 2000 que pleiteavam a isenção de taxa para vestibulandos carentes, verificou-se 42 diferentes ações; destas, 38 envolviam 410 pessoas que estavam requerendo a isenção; as quatro ações restantes eram de caráter geral, pedindo o benefício para todos os alunos da rede pública. Estas últimas foram movidas pelo advogado Luiz Eduardo Greenhalg, pela pessoa de Frei David Raimundo dos Santos, pela EDUCAFRO e por Dom Paulo Evaristo Arns. Pelo que consta, todas as 42 foram incentivadas ou protagonizadas pelo diretor da EDUCAFRO.

Não se verificou nenhuma ação anterior a 1998; naquele ano foram 4 ações individuais e coletivas, envolvendo 46 estudantes, e também as ações movidas por Luiz Eduardo Greenhalg e Dom Paulo Evaristo Arns. No ano de 1999 as ações envolveram 364 pessoas, e no ano de 2000 registrou-se apenas as de autoria de Frei David Raimundo dos Santos e a da EDUCAFRO. A ação movida por Dom Paulo Evaristo Arns, pela importância de seu proponente e repercussão, foi escolhida para ser analisada.

A ação popular de número 1427/98, apresentada na $9^{a}$ Vara da Fazenda Pública da Comarca da Capital, em 23 de setembro de 1998, de autoria do Cardeal Emérito de São Paulo, teve como ré a USP - Universidade de São Paulo. A presença do sacerdote como autor da ação foi arquitetada pelo diretor geral da EDUCAFRO.

$\mathrm{O}$ advogado que representou $\mathrm{D}$. Paulo tinha larga experiência neste tipo de ação, tendo atuado junto ao PVNC no Estado do Rio de Janeiro. Sentenças vitoriosas naquele estado foram anexadas ao processo para mostrar a existência de decisões favoráveis em causas semelhantes.

A ação popular trouxe o seguinte pedido de liminar: 
Para que seja ordenado a ré que aceite gratuitamente as inscrições em seu concurso vestibular 1999, dos candidatos que:

a) concluíram ou estão concluindo seu curso de $2^{\circ}$ grau em instituição pública municipal, estadual ou federal, ou

b) que declarem, na forma prevista no Artigo $1^{\circ}$ da Lei 7.115, de 29 de agosto de 1983, não poder arcar com o custo da taxa de inscrição sem comprometer seu próprio sustento,

efetivando-se suas inscrição (sic) em datas fixadas por esse $\mathrm{Mm}^{\circ}$ Juízo.

Inicialmente, apresentou-se uma introdução à questão da gratuidade da taxa, na qual, dentre vários pontos, tem-se a jurisprudência dos tribunais fluminenses:

1. A ré é uma instituição de ensino superior pública e gratuita, e recentemente publicou o Edital de seu Concurso Vestibular 1999, nos termos da Resolução CoG 4568, de 02 de junho de 1998, oferecendo 7.036 vagas.

2. Entretanto, inobstante o ensino ministrado pela ré ser gratuito, a mesma, no Artigo $5^{\circ}$ do referido Edital delegou à Fundação Universitária para o Vestibular - FUVEST o poder de estipular uma taxa de inscrição no referido Concurso Vestibular.

3. Foi então estipulada a taxa de inscrição em R\$ 50,00 (cinqüenta reais), quantia evidentemente fora das possibilidades de estudantes carentes.

4. Como o valor da taxa cobrada é aparentemente reduzido, deixa o caráter discriminatório da cobrança de ser percebido, à primeira vista. Entretanto, é preciso lembrar as condições do País em que vivemos.

5. Segundo números do IBGE, in "Anuário do Brasil 1994", página 2-75, $68,9 \%$ das pessoas com 10 ou mais anos de idade, residentes em domicílios urbanos na Região Sudeste possuem renda mensal inferior a três salários mínimos.

6. Para esses cidadãos - para seus filhos - a taxa de inscrição é uma taxa de exclusão.

7. A ré não abre qualquer espécie de exceção, não existindo no Edital qualquer hipótese de isenção da malsinada taxa de inscrição.

8. Assim fica a maioria dos estudantes pobres excluída do direito de participar do Concurso Vestibular da USP, por não terem condições de pagar a inscrição, sem comprometer o sustento de sua família. 
9. Esta é mais uma peça cruel da engrenagem da exclusão social: negar à família pobre o acesso à educação superior pública. Os alunos pobres que concluíram o $2^{\circ}$ grau alcançaram algo que, para os brasileiros de origem humilde é infelizmente vitória de poucos.

10. A sociedade lhes disse “- Estudem", e eles estudaram. Agora, quando pretendem aprimorar sua formação, fecham-se-lhes as portas, sem que nem lhes seja dada a chance de tentar.

11. No Estado do Rio de Janeiro, outra Universidade Estadual Pública, a UERJ, também impõe a cobrança de taxa de inscrição para certame vestibular, e, diferentemente da ré, oferece ainda 6.000 isenções de taxa para os candidatos mais pobres.

12. Entretanto, mesmo tal "concessão" foi vigorosamente espancada em Acórdão unânime, da E. $10^{\mathrm{a}}$ Câmara Cível, Relator o Exm $^{\circ} \mathrm{Sr}$. Desembargador Bernardino Leituga:

"TAXA DE INSCRIÇÃO NO VESTIBULAR. ISENÇÃO. LIMITE. A isenção da taxa de inscrição deve obedecer às condições de pobreza do interessado, não podendo haver limite. É irrelevante que o número de carentes seja maior do que o limite previsto. Recurso provido."

13. Em análoga ação popular, a Exm ${ }^{\mathrm{a}}$ Juíza Helena Belc Klusner, da $5^{\mathrm{a}}$ Vara da Fazendo Pública da Comarca do RJ, concedeu liminar, para que todos os candidatos carentes prestassem o Vestibular da UERJ gratuitamente:

"Tendo em vista que todos devem ter acesso à educação - primado constitucional -, defiro a liminar nos termos requeridos, isto é, àqueles que tempestivamente requiseram isenção do pagamento da taxa de inscrição."

14. Ainda em sede de ação popular, o $\operatorname{Exm}^{0}$ Juiz Guilerme Bolorini Pereira, da $21^{\mathrm{a}}$ Vara Federal da $2^{\mathrm{a}}$ Região, concedeu liminar, garantindo o acesso gratuito dos candidatos carentes ao vestibular da Universidade do Rio de Janeiro, valendo destacar suas exemplares palavras:

"Instituições públicas de ensino existem para proporcionar acesso justamente a pessoas que não podem arcar com os altos custos das mensalidades cobradas pelas universidades privadas. Não será àquelas, que são a razão de ser de uma instituição pública de ensino, de primeiro, segundo ou terceiro graus, que se negará acesso ao exame de admissão."

15. Por derradeiro, cabe aduzir que o Manual do Candidato ao Vestibular 1999 da USP fixa as últimas datas de entrega das fichas de inscrição para os dias 26 e 27 de setembro de 1998, fato que será relevante para apreciação do periculum in mora. (grifos do autor) 
Foi alegada a inconstitucionalidade da cobrança da taxa de inscrição por quatro diferentes motivos. O primeiro diz respeito a:

OS OBJETIVOS FUNDAMENTAIS DA REPÚBLICA

Dispõe o artigo $3^{\circ}$ da Constituição Federal:

"Constituem objetivos fundamentais da República Federativa do Brasil:

I - Construir uma sociedade livre, justa e solidária.

II - Garantir o desenvolvimento nacional.

III - Erradicar a pobreza e a marginalização e reduzir as desigualdades sociais e regionais.

IV - Promover o bem de todos, sem preconceitos de origem, raça, sexo, cor, idade e quaisquer outras formas de discriminação."

Para a construção da República, a educação do cidadão é pressuposto essencial; é transparente que, para a realização da voluntas legis contida em cada um dos incisos do referido, dever-se-á dar educação ao nosso povo, sofrido e laborioso.

Onde a construção de uma "sociedade livre, justa e solidária", se é negado o acesso do cidadão à universidade pública, apenas por sua pobreza não lhe permitir dispor de $\mathrm{R} \$ 60,00$ ?

Onde "erradicar a pobreza", se é negada justamente ao pobre a educação que lhe permitiria construir uma vida mais digna?

Onde "promover o bem de todos, sem preconceitos (...)" se o próprio Poder Público, através de uma de suas universidades, discrimina o cidadão pobre?

Respondidas as perguntas anteriores pela negativa, quem garantirá o "desenvolvimento nacional", se nega-se curso àquela "força que nasce em meio à pobreza e faz dos fracos riqueza", através do qual poder-se-ia construir uma sociedade mais justa, harmônica e feliz?

A segunda inconstitucionalidade aborda a questão da igualdade:

Dispõe o caput do Artigo $5^{\circ}$ da Constituição Federal:

"Todos são iguais perante a lei, sem distinção de qualquer natureza, garantindo-se aos brasileiros e aos estrangeiros residentes no país a inviolabilidade do direito à vida, à liberdade, à igualdade, à segurança, $\mathrm{e}$ à propriedade."

Dispõe o Artigo 206, e seu inciso I, da Constituição Federal: 
“O ensino será ministrado com base nos seguintes princípios:

I - igualdade de condições para o acesso e permanência na escola; [...]"

Ora, a cobrança de taxa de inscrição para acesso ao ensino superior público constitui maneira censitária de discriminação entre os cidadãos candidatos.

A taxa cobrada parece ser igual para todos. Mas, na realidade, não o é em termos relativos; e o princípio da igualdade constitui em tratar igualmente os iguais e desigualmente os desiguais, na medida em que eles desigualam.

Não satisfeito em haver inserido a Igualdade como Direito Fundamental Pétreo, o constituinte, para não restarem dúvidas na aplicação da Carta Magna, tornou a mencionar a Igualdade no Artigo 206, I, para garantir a todos o acesso à escola.

Pode-se argumentar que as taxas de inscrição já são cobradas nos vestibulares de universidades públicas faz anos. Mas a prática reiterada da imoralidade não premia o infrator, nem dá ao erro foros de legalidade; abusus nec facit iuris!

Como terceiro elemento questionador da constitucionalidade do edital, aborda-se o tema da gratuidade do ensino público:

Dispõe o artigo 206, e seu inciso IV, da Constituição Federal:

"O ensino será ministrado com base nos seguintes princípios:

IV - gratuidade do ensino público em estabelecimentos oficiais;"

A Constituição Federal prevê a gratuidade do ensino público, que não se pode pretender que beneficie apenas os graduandos. Será que é juridicamente aceitável a "gratuidade apenas da porta para dentro"?

[...] a cobrança da taxa de inscrição é um abuso claramente incompatível com a vontade constitucional, pois as atividades seletivas devem ser reconhecidas como uma parte integrante da educação, alcançadas pois pela gratuidade constitucional.

Até porque, ao estabelecer esse princípio, o legislador constitucional o fez para que jamais um brasileiro fosse excluído da escola por sua pobreza.

O último argumento diz respeito ao acesso segundo a capacidade de cada um, como também consta em texto constitucional. 
Dispõe o artigo 208, e seu inciso V da Constituição Federal:

\section{“O dever do Estado com a educação será efetivado mediante a garantia de:}

V - acesso aos níveis mais elevados do ensino, da pesquisa e da criação artística, segundo a capacidade de cada um;"

Assim, a taxa de inscrição no vestibular é requisito írrito para o acesso ao ensino superior, que a Constituição condiciona tão-somente à capacidade do estudante.

A ninguém é dado diferenciar onde a Lei não diferencia. A Lei Maior disse "acesso segundo a capacidade de cada um", não disse "desde que pague as taxas exigidas para que tenha acesso".

Apesar da argumentação ali presente, o pedido foi indeferido pela Juíza

Maria Fernanda de Toledo Rodovalho Podval, em 23 de setembro de 1998:

A taxa, por si própria, não pode ser entendida como restrição ao acesso ao ensino público.

Aliás, se o recolhimento de inscrições é definido como taxa (exigível, no caso, pela prestação de um determinado serviço de aferição e avaliação do candidato), o pagamento é mera condição para que a avaliação da capacidade (esta, sim, necessária ao ingresso na universidade pública) venha a ser feita. Isso significa que a taxa apenas torna possível a implementação do princípio de que o acesso às universidades públicas se faça em razão da capacidade do candidato.

$[\ldots]$

Se há um custo para a elaboração e correção de provas, a universidade deve, até mesmo em nome desse mesmo princípio da moralidade, calcular quanto cada candidato deva pagar para se submeter aos exames.

Poderia ser aventada a hipótese de que, por ser universidade pública, mesmo o concurso de ingresso devesse ser gratuito (para todos, evidentemente), mas esse não é o pedido do autor.

Mesmo que tivesse sido esse o requerimento, uma vez que há serviço prestado, é legítima a exigência de contraprestação financeira. Ademais, a isenção - porque é isso que postula o autor - não conta com amparo jurídico. E nem pode o Judiciário, avaliando a conveniência e oportunidade de conceder isenções substituir-se ao Executivo.

Por fim, cabe assinalar que os fundamentos das decisões dos Tribunais do Rio de Janeiro não se aplicam ao caso da USP. O que parece ter motivado o reconhecimento da irregularidade da taxa de inscrição das universidade cariocas não foi tanto a cobrança de um determinado valor (ainda que alto), mas a concessão, sem critérios pré-definidos, de isenções. Isso sim, seria ofensivo à moralidade administrativa. As decisões acostadas aos autos 
demonstram que os candidatos foram favorecidos pelo reconhecimento da pertinência desse ponto.

Ante o exposto, indefiro o pedido de liminar.

Nas ações movidas por grupos de alunos, algumas foram vitoriosas; 42 estudantes realizaram o exame sem o pagamento da taxa em 1998. Os pedidos foram acompanhados por uma declaração de pobreza dos interessados em realizar o exame sem o pagamento da taxa. Seus resultados, na primeira fase, giraram em torno de 40 pontos dentre 160 possíveis.

A entrega dos processos judiciais foi antecedida de várias manifestações na porta da fundação, onde declarações de pobreza, que relatavam a situação de vida dos estudantes e o porquê da impossibilidade do pagamento da taxa, foram afixadas nas grades que protegem o local. Participaram das manifestações alunos da EDUCAFRO, Paulo Freire, Núcleo de Consciência Negra e Thema, bem como seus coordenadores, que também realizaram várias reuniões com os dirigentes da fundação. (Picanço, 2 set. 1999, p.8)

No ano seguinte, a FUVEST, pressionada, resolveu conceder cinco mil isenções. Os contemplados seriam os alunos provenientes do Ensino Médio público com boa colocação no ENEM.

Apesar dessa iniciativa ter sido considerada uma grande vitória, ela desagradou os defensores da isenção. O candidato deveria realizar o exame organizado pelo governo federal e, posteriormente, o vestibular, pagando duas taxas em vez de uma e sem a certeza da devolução do valor empenhado, uma vez que atrelada ao resultado no exame. A publicação da nota do ENEM só ocorreu após a data de inscrição no exame de acesso à USP; assim não se tinha conhecimento dos beneficiados pelo processo e a restituição só se deu na primeira prova da etapa inicial da seleção.

A forma encontrada pela FUVEST também associava a isenção ao mérito, colocando em plano secundário uma questão essencial: a da carência financeira dos vestibulandos. Os alunos contemplados poderiam até ter condições de arcar com essas despesas, já que nem todos estudantes da rede pública estão numa condição de penúria econômica. 
Devido ao grande número de empates na última colocação, 5.510 vestibulandos obtiveram o reembolso, mas cerca de setecentos e cinqüenta deixaram de recolher o valor disponível nas agências bancárias ${ }^{13}$. Essa desistência da recuperação do gasto foi vista pela FUVEST como um sinal de que talvez o preço do exame não seja tão impeditivo como alegado pelos alternativos. A fundação também reconheceu problemas na forma como foi organizada a concessão.

No ano de 2000, a Pró-Reitoria de Graduação da USP solicitou que a Comissão de Direitos Humanos da Ordem dos Advogados do Brasil seção de São Paulo intermediasse as negociações com os cursinhos alternativos, agora organizados em Fórum. Essas negociações envolveram também os vestibulares da UNICAMP e UNESP.

A proposta inicial formalizada pelo Fórum previa que não se cobrasse inscrição dos alunos formados em escola pública (seja qual fosse o ano), com renda familiar de até $\mathrm{R} \$ 973,80$ para quatro pessoas. As universidades, por sua vez, ofereceram doze mil e setecentas vagas. No acordo firmado, foram concedidas 16.355 (dezesseis mil trezentas e cinqüenta e cinco) isenções, sendo dez mil na USP.

A distribuição ficou a cargo do Fórum dos Cursinhos Alternativos e Comunitários do Estado de São Paulo. Uma parte foi destinada aos seus filiados, e outra, sorteada entre aqueles que solicitassem o benefício. Para tanto, não poderiam estar vinculados a nenhum pré-vestibular comercial, atender a critérios básicos, como ter realizado a educação básica pública, e ter renda inferior a $\mathrm{R} \$$ 243,45 por membro da família.

A distribuição entre os cursinhos atendeu ao critério de proporcionalidade por número de alunos. Assim, o da Poli, com maior número, ficou com 4.000 isenções. Segundo reportagem do jornal O Estado de São Paulo, alguns alunos do Cursinho da Poli, que não foram contemplados na distribuição e no sorteio,

\footnotetext{
${ }^{13}$ A FUVEST organizou a devolução de forma que o dinheiro estivesse disponível na agência do Banespa mais próxima à residência do vestibulando.
} 
chegaram a realizar pedágio para conseguir dinheiro para a taxa. (OESP, $27 \mathrm{dez}$. 2000, p. A-7)

Findo o exame que selecionou universitários para a matrícula em 2001, a FUVEST fez uma avaliação negativa da experiência. Das dez mil isenções concedidas, apenas sete mil quinhentas e quinze foram utilizadas; além disso, o índice de abstenção do grupo - 16,8\%, foi superior à média da primeira fase; apenas $5 \%$ dos alunos contemplados obtiveram classificação para a $2^{\text {a }}$ fase do exame, e ocorreram 125 aprovações. O índice de aprovado/inscrito foi de 1,7\% enquanto no total da FUVEST, foi de 6,7\%. (Cafardo, 11 jan. 2001, p.A14. FSP, 11 set. 2001, p.C4)

A pressão exercida pelos cursinhos conseguiu sensibilizar a USP para a questão da taxa de inscrição, que incrementou, ano após ano, o número de alunos contemplados. Mas a desistência em fazer as provas e o fraco desempenho dos vestibulandos questionariam a real importância desse obstáculo para a matrícula.

A VUNESP, que já possuía um programa de isenção que procurava estimular a inscrição em carreiras de licenciatura, cedeu no vestibular de 2000 um total de 1.364 isenções para a EDUCAFRO; no ano seguinte, foram 4.000, destinadas aos cursinhos associados ao Fórum; além destas, ainda ofereceu 1.059 para os cursinhos patrocinados pela UNESP. Num relatório detalhado, é possível observar o perfil sócio-econômico do conjunto dos alunos dos pré-vestibulares associados ao Fórum e dos vinculados à UNESP. Eis abaixo algumas características selecionadas do grupo:

- 96\% cursaram o Ensino Fundamental todo em escola pública;

- $98 \%$ cursaram o Ensino Médio todo em escola pública;

- $48 \%$ estudaram no período noturno (todo o curso ou a maior parte dele);

- $53 \%$ têm renda familiar entre 2 e 4,9 salários mínimos.

Foram utilizadas 3.175 das inscrições cedidas ao Fórum, e 666 das oferecidas aos cursinhos da UNESP. Desses, 2.722 alunos compareceram às provas, e ocorreram 175 aprovações. A relação aprovado/inscrito para esses alunos foi de 4,6\%; no total da UNESP essa mesma relação foi de $6,4 \%$. (VUNESP, 2001a. VUNESP, 2001b) 
O alto custo do vestibular para o candidato ainda suscitou a discussão da reunificação do exame das três universidades estaduais, que se daria somente na primeira fase, com a segunda sendo realizada separadamente em cada instituição. As vantagens seriam um menor desgaste do candidato, o barateamento do processo e uma única fila para as isenções. No ano de 2000, a soma do valor das inscrições chegou à cifra de $\mathrm{R} \$ 180,00$. (Junqueira, 26 out. 1999, p. A13)

$\mathrm{O}$ questionamento sobre o preço dos exames não é exclusividade dos alternativos. No interior de São Paulo, um professor de cursinho organizou e encaminhou ao MEC um abaixo-assinado de 20 mil estudantes propondo preço único para o exame das particulares - $\mathrm{R} \$ 20,00$ - e a realização de provas gratuitas nas escolas públicas. (Aceituno, 11 set. 1999, p. A-10)

Os cursinhos alternativos colocaram em evidência questões como unificação dos vestibulares, isenção da taxa e preços mais acessíveis. Embora elas já estivessem em pauta, as manifestações na porta da FUVEST e ações judiciais apressaram a procura de soluções para uma questão que deverá se agravar com a expansão da matrícula do Ensino Médio para a população mais pobre.

\subsection{Ingresso como aluno especial na USP}

Em dezembro de 1999, treze estudantes vinculados à EDUCAFRO, divididos em dois grupos, entraram com mandado de segurança com pedido de liminar contra a Universidade de São Paulo para que esta os aceitasse como alunos especiais nas disciplinas de graduação.

Nos mandados de segurança, elaborados pelo advogado José Agostinho M. Galvão de Barros Filho, os alunos foram apresentados como pessoas sem condições de arcar com os custos dos cursos particulares em que estavam ou foram matriculados. Abaixo seguem algumas das descrições dos estudantes (nomes fictícios): 
GLÓRIA O. S., matrícula trancada no curso de Engenharia da Universidade Paulista - UNIP. Na $2^{\circ}$ série, não possui renda mensal fixa, uma vez que vive de venda de lanches, salgado, café e marmita no centro da cidade de São Paulo/SP. Não possui pai e a mãe é inválida, mensalidade de R $\$ 703,40$ (setecentos e três reais e quarenta centavos), conforme declaração e documentos $\mathrm{n}^{\mathrm{o}} 08$ em anexo;

GUSTAVO A. P., matriculado no curso de Direito da Universidade São Francisco, no $3^{\circ}$ semestre, aposentado por invalidez (linfedema crônico) pelo INSS, com renda mensal da aposentadoria de R\$182,00 (cento e oitenta e dois reais), mensalidade integral de $\mathrm{R} \$ 398,00$ (trezentos e noventa e oito reais), conforme declaração e documentos $\mathrm{n}^{\circ} 10 \mathrm{em}$ anexo;

GIULIANA S. F., matriculada no curso de Turismo da Universidade Ibero Americana, no $1^{\circ}$ semestre, com renda mensal familiar de $\mathrm{R} \$ 810,00$ (oitocentos e dez reais) dela dependendo quatro familiares, mensalidade de $\mathrm{R} \$ 429,00$ (quatrocentos e vinte e nove reais), em débito com quatro mensalidades atrasadas, conforme declaração e documentos $\mathrm{n}^{\circ} 13$ em anexo;

Após a apresentação de todos, conclui:

Tratam-se de alunos afrodescendentes ou carentes, egressos do segundo grau em escola pública e que agora encontram-se matriculados em curso superior em instituições privadas, mas sem condições financeiras de arcar com as mensalidades sem prejuízo do sustento próprio e familiar.

São, na totalidade, alunos ligados ao Movimento dos Pré-Vestibulares Comunitários para Alunos Negros e Carentes, direcionado para a educação do jovem pobre, fundado em 1993, a EDUCAFRO - Educação e Cidadania para Afrodescendentes e Carentes.

Nesse movimento, estudantes de nível superior, e mesmo profissionais já diplomados, ministram gratuitamente aulas para estudantes carentes, que se preparam para prestar concurso vestibular, e que, em face do notório naufrágio do ensino público de $2^{\circ}$ grau, não teriam condições de ser aprovados para uma faculdade pública.

Citando o artigo 205 do Regimento Geral da USP, que permite a matrícula em disciplinas isoladas de graduação ou pós-graduação para estudantes que tenham concluído o segundo grau ou superior, justifica-se o mandado da seguinte forma:

A Universidade de São Paulo nega-se terminantemente a fornecer os dados necessários e a proceder a matrícula dos impetrantes, em disciplinas 
isoladas, na qualidade de alunos especiais, conforme determina o seu Regimento Interno, em um flagrante ato de ilegalidade.

Dessa forma, o direito desses alunos de cursar tais disciplinas estaria prejudicado:

O direito - faculdade dos impetrantes - está sendo obstado ilegalmente pela impetrada, que se nega a matriculá-los como aluno especial.

É um direito líquido e certo dos impetrantes que está sendo violado, maculado e desrespeitado pela impetrada.

Para os impetrantes, na atual conjuntura de exclusão social e face às dificuldades financeiras que estão passando, matricular-se em disciplinas isoladas, como aluno especial, é a única forma de continuarem seu estudo e a alternativa à evasão, uma vez que as matérias cursadas poderão ser aproveitadas futuramente em qualquer instituição de ensino superior.

A impetrada deveria simplesmente proceder a matrícula dos impetrantes como aluno especial, não havendo qualquer discricionariedade que poderia justificar sua conduta ilegal, imoral e injusta, de negar ou dificultar ao máximo a matrícula dos impetrantes em disciplinas isoladas, como aluno especial.

No mandado ainda se procura mostrar a existência de vagas com base nos dados de evasão da USP:

A impetrada argumenta que não seria possível a matrícula dos impetrantes em disciplinas isoladas, como aluno especial, face à inexistência de vagas para recebê-los.

No entanto, não é isso que falam os números apontados no Anuário Estatístico da Universidade de São Paulo - USP (doc. $\mathrm{n}^{\circ}$ 14, em anexo), dos anos de 1991 a 1998, sendo que no ano de 1998 foram oferecidas 6.920 vagas de graduação, ofertadas pelo vestibular da FUVEST e, neste mesmo ano, apenas 4.276 alunos conseguiram diplomar. Isto indica uma relação formado/vaga de $66,1 \%$, ou seja, uma evasão de $33,9 \%$ dos alunos.

Nos anos anteriores esta relação não é tão diferente, a saber:

1- em 1997 a relação formado/vaga foi de 61,1\%, com uma evasão de $38,9 \%$;

2- em 1996 a relação formado/vaga foi de 62,9\%, com uma evasão de $37,1 \%$;

3- em 1995 a relação formado/vaga foi de 59,5\%, com uma evasão de $40,5 \%$; 
4- em 1994 a relação formado/vaga foi de $61,3 \%$, com uma evasão de $38,7 \%$.

Assim, a cada ano são mais de 2.000 alunos que não obtêm o diploma nos mais diversos cursos da Universidade de São Paulo, conforme demonstra o anuário estatístico em anexo.

$[\ldots]$

A evasão, nos atuais padrões da USP, é inaceitável, pois, como autarquia estadual, recebe verba anualmente, diretamente destinada do orçamento estadual e orçada em face das 6.920 vagas e não dos 4.576 formados. É um flagrante caso de desperdício de dinheiro público.

O dinheiro público destinado à Universidade de São Paulo é colocado anualmente a disposição desta, com base nas 6.920 vagas oferecidas, mas face a quase 2.000 vagas ociosas em decorrência da evasão, nada mais justo que sejam aproveitadas pelos impetrantes, como aluno especial, cursando matérias em disciplinas isoladas.

Justificar a não possibilidade dos impetrantes de matricularem-se em disciplinas isoladas como aluno especial pela falta de vaga, é completamente improcedente, face ao número de vagas ociosas na universidade, fruto da evasão de em média $38 \%$ dos alunos regularmente matriculados e egressos do vestibular da FUVEST.

Há vaga e bastante, em quase a totalidade dos cursos de graduação da universidade, para matrícula dos impetrantes como aluno especial, sendo completamente inverídica a afirmação da impetrada de falta de vaga para oferecimento a alunos especiais.

Foi também incluso, nos documentos anexos, um artigo no qual se aponta a necessidade de realizar a transferência de alunos de outras IES, ou a abertura para alunos especiais das vagas remanescentes por evasão na USP, uma vez que a própria LDB determina esse procedimento. (Bacchetto, 15 a 21 nov. 1999, p.2).

A Pró-Reitoria de Graduação da USP entrou em acordo com a EDUCAFRO de modo a permitir a matrícula dos alunos especiais nos cursos, orientando suas unidades a aceitar a inscrição. A EDUCAFRO passou a estimular que seus alunos, já ingressos em outros cursos ou apenas com o diploma de Ensino Médio, se inscrevessem para as vagas oferecidas.

No ano de 2000 a Pró-Reitoria de Graduação anunciou um programa de transferência organizado pela FUVEST. Foram oferecidas 1.265 vagas com seleção realizada em 30 de julho daquele ano. Em entrevista ao jornal Folha de $S$. Paulo, a pró-reitora Ada Pelegrini Grinover relata ter realizado no ano anterior 
cerca de 400 transferências e atribuiu o aumento à informatização, que centralizou as informações. (Gois, 18 fev. 2000, p.7)

No plano de metas produzido pela Pró-Reitoria de Graduação para o biênio 2000/2001, por ocasião da renovação do mandato da então pró-reitora, não é feita qualquer menção à abertura de vagas por transferência, o que é no mínimo estranho, se considerarmos o grande número oferecido. (Grinover, 1999)

Não se registrou nenhum outro elemento que explicasse o crescimento de três vezes no número de vagas para transferência na USP; talvez o pedido dos estudantes vinculados à EDUCAFRO tenha apressado uma resposta da universidade ao alto número de alunos evadidos, já que um dos argumentos apresentados baseava-se justamente nesse tópico.

Mesmo que não haja uma vinculação direta entre a ação judicial e a abertura dessas vagas, fica registrado o movimento pelo ingresso de alunos na universidade pública por outros caminhos que não o vestibular.

\subsection{A isenção da taxa de inscrição do ENEM}

Com o aumento do número de participantes, advindo da utilização dos resultados do ENEM em diversos processos seletivos, surgiu a reivindicação pelo fim da taxa de inscrição. No ano de 1999 , seu valor foi de R $\$ 20,00$, e no ano subseqüente sofreu aumento de $\mathrm{R} \$ 5,00$.

Várias ações judiciais, uma primeira no interior de São Paulo, seguida de outras no Espírito Santo, Rio de Janeiro, Paraná e interior de Minas Gerais, procuraram garantir a gratuidade na inscrição do ENEM para alunos que estudaram em escolas públicas ou alegassem carência de recursos. Quase 60 mil estudantes foram beneficiados dentre os 390.574 participantes. (FSP, 27 jul. 2000, p.C-4)

O Procurador da República Paulo Eduardo Bueno, atendendo a pedido do Conselho Municipal de Educação de Ribeirão Preto, moveu o primeiro processo pedindo que fosse:

[...] concedida MEDIDA LIMINAR [...] no sentido de determinar a suspensão da cobrança de tal taxa para os alunos carentes, situação esta que poderá ser comprovada mediante simples declaração dos pais ou 
responsáveis ou apresentação de documento que comprove ser o aluno originário de escola pública;

A argumentação pela gratuidade baseou-se no preceito constitucional da igualdade, na farsa que seria a opcionalidade pelo exame - uma vez que os cursos superiores contam a nota obtida para ingresso - e no valor abusivo frente ao salário mínimo nacional:

Em 13 de junho, o Ministério Público Federal de Ribeirão Preto/SP recebeu representação solicitando providências quanto à possível utilização das notas da avaliação do ENEM - Exame Nacional do Ensino Médio -, como forma de ingresso nos estabelecimentos públicos e privados de ensino superior, em anexo.

Segundo a referida representação, além de servir de parâmetro para ingresso no ensino superior, o aluno que quiser se submeter ao ENEM tem que desembolsar o valor de $\mathrm{R} \$ 25,00$ (vinte e cinco reais), o que excluiria o candidato carente, ferindo, desta forma, o princípio da isonomia, garantido pela Constituição Federal.

Com efeito, o ENEM foi instituído pela Portaria MEC no 438, de 28 de maio de 1998, tendo como principal objetivo oferecer subsídios para que o participante faça uma auto-avaliação, e assim possa orientar melhor suas escolhas e seus projetos futuros, fornecendo elementos para as diferentes modalidades de acesso à educação superior (incisos I, II, III e IV).

De acordo com a referida Portaria, dado o seu caráter excepcional, os interessados em participar dos exames pagarão uma taxa de inscrição cujo valor será fixado anualmente pelo INEP - Instituto Nacional de Estudos e Pesquisas Educacionais $\left(\operatorname{art.} 5^{\circ}, \S 1^{\circ}\right.$ ) -, o que ressalta a legitimidade passiva deste.

Para o ano de 2000 foi fixada uma taxa no valor de $\mathrm{R} \$ 25,00$ (vinte e cinco reais), estabelecida no Anexo I da Portaria ${ }^{\circ}$ 06/2000- INEP, que deverá ser paga nas agências dos Correios do Estado.

$\mathrm{O}$ valor de $\mathrm{R} \$ 25,00$ (vinte e cinco reais) cobrado indistintamente dos candidatos interessados em participar do ENEM fere realmente o princípio da isonomia, uma vez que exclui o mais carente de participar da prova.

Nem se alegue que a participação no ENEM é voluntária, como forma de justificar a referida cobrança, uma vez que, ao servir de parâmetro para ingresso nos cursos de ensino superior, não se mostra tão opcional para quem tem interesse de ingressar no $3^{\circ}$ grau.

No Estado de São Paulo, o caráter não opcional do exame se mostra na medida em que a USP, a universidade estadual mais conceituada e concorrida, adotará como parâmetro para ingresso nos seus quadros a nota do ENEM, no valor de até $25 \%$ do total de pontos da prova objetiva. 
Sendo assim, o abusivo valor de $\mathrm{R} \$ 25,00$ (vinte e cinco reais) se traduzirá, na prática, em mais um obstáculo para ingresso de alunos de baixa renda nas universidades e faculdades mais conceituadas do país, tanto na USP como em outras que adotarão o critério da nota do ENEM como parâmetro para ingresso nos seus quadros, conforme demonstra a documentação em anexo.

Em um país em que o valor do salário mínimo é de R \$151,00 (cento e cinqüenta e um reais), não há como negar que $\mathrm{R} \$ 25,00$ (vinte e cinco reais) pesam no bolso da maioria da população, que se veria excluída de participar do referido "provão", e, quem sabe, sonhar em ingressar um dia em um curso de nível superior.

O Legislador Constituinte, ao promulgar nossa atual Carta Magna, fez a opção por um Estado igualitário, no qual todos os cidadãos tivessem oportunidades isonômicas. Isto significa, sobretudo, acesso a todos aos meios adequados à consecução dos fins almejados pela Lei Maior: a construção de uma sociedade livre, justa e solidária, calcada nos valores sociais do trabalho, da cidadania e da dignidade da pessoa humana.

A realidade fática, porém, destoa completamente dos rumos traçados na Constituição. Diferentemente do que foi consignado pelo Constituinte, o que se vê é um processo sempre crescente de exclusão social, no qual os estamentos sociais são conservados por um sistema descomprometido com os valores impostos pela Constituição Federal.

Neste contexto, os menos favorecidos economicamente vêem negado o direito fundamental à educação, tendo em vista que o Estado notoriamente não cumpre com as funções que lhe foram outorgadas, entre elas oferecer ensino público gratuito e de qualidade.

Por certo que ao cobrar indistintamente a taxa de $\mathrm{R} \$ 25,00$ (vinte e cinco reais) para todos os candidatos interessados em se submeter ao ENEM há evidente afronta ao Texto Magno, uma vez que não leva em consideração as desigualdades econômicas existentes entre a população, sendo necessária a correção da distorção, de forma a possibilitar oportunidades iguais de ingresso à educação de ensino superior.

Era necessário ter uma declaração de carência ou comprovante de ser aluno da rede pública para conseguir a isenção. Na capital paulista os alternativos organizaram uma manifestação em frente ao prédio dos correios com aproximadamente 500 pessoas que obtiveram a gratuidade. (FSP, 20 jun. 2000, p.C-6)

O Ministério da Educação recorreu das ações, disse pretender cobrar o valor daqueles que pudessem pagar e anunciou para o exame de 2001 uma seleção sócio-econômica para isentar somente aqueles que necessitam. Entretanto, o MEC não conseguiu reverter a decisão judicial e acabou 
incorporando a gratuidade para os alunos da rede pública e os carentes da rede particular. Aproximadamente $83 \%$ dos estudantes que realizaram o ENEM em 2001 o fizeram gratuitamente.

\subsection{Reivindicando junto ao Estado a aprendizagem dos conteúdos do vestibular}

Um elemento que a EDUCAFRO apontou como responsável pelo fracasso dos alunos da rede pública no vestibular foi a má qualidade do ensino público. A forma mais explícita desta seria a falta de professores em determinadas disciplinas e a aprovação do aluno sem que o conteúdo seja aprendido.

A EDUCAFRO emitiu uma declaração na qual considerava que os diplomas de Ensino Médio concedidos pelo Estado de São Paulo seriam "ato jurídico simulado", pois as aulas necessárias para a obtenção do título não teriam ocorrido:

[...]

4. Ora, é evidentemente inverídico o conteúdo de um diploma que contenha declaração de suficiência acadêmica em relação a disciplinas que nem sequer foram ministradas. É ATO JURÍDICO SIMULADO!

5. Na verdade, os entes estatais, incapazes, ou, mais provavelmente, desinteressados, de oferecer ensino publico gratuito de qualidade, valem-se de tal subterfúgio para desonerar-se das obrigações que lhes são impostas pela Constituição Federal e pela LDB.

6. Contam com a cumplicidade do aluno, naquela velha visão que "importante é o canudo", e lhe dão um certificado de conteúdo inverídico, certos que o aluno será o ultimo a dizer que, na verdade, nada sabe sobre algumas disciplinas nas quais é dado como aprovado. (EDUCAFRO, nov./dez. 2000)

Em se comprovando que o aluno deixou de ter o quadro de aulas ou os conteúdos programados, o Estado não cumpriu sua função, impedindo que o aluno fosse aprovado nos vestibulares mais concorridos e progredisse aos mais altos níveis do ensino, podendo requerer indenização. A comprovação seria através da apresentação de boletins escolares e do testemunho de colegas e professores sobre a ausência do conteúdo exigido; além disso, seria utilizado o resultado do Sistema de Avaliação da Educação Básica para demonstrar a 
precariedade do ensino público frente ao particular, que obtém os melhores resultados. (FSP, 3 dez. 2000)

Não se tem conhecimento se a EDUCAFRO processou o Estado de São Paulo ou se o fato permaneceu apenas no plano das intenções e da denúncia.

\subsection{Reserva de vagas para alunos da rede pública}

Como apenas a gratuidade dos exames não garante a matrícula dos alunos menos favorecidos, a EDUCAFRO, inspirada no projeto de lei do senador Antero Paes de Barros - já citado anteriormente -, procurou garantir a reserva de metade das vagas na USP para alunos oriundos do ensino público, requerendo, através de uma representação, que o Ministério Público de São Paulo intercedesse pela reserva de vagas.

Processos semelhantes já haviam obtido vitória inicial em outras unidades da federação. No Ceará, em Ação Civil Pública movida pelo Ministério Público, o juiz alegou que o processo seletivo era desigual por nivelar pessoas com diferentes graus de preparação e que estatisticamente era possível observar reserva de 'mercado' apenas para os alunos da rede privada. Em Minas Gerais liminar semelhante foi concedida com a argumentação de que a reserva seria uma forma de evitar dano futuro de difícil reparação aos alunos da rede pública. Num segundo momento, com os recursos da UFMG e UFC, as liminares foram derrubadas e os vestibulares mantiveram sua versão original.

Na ação civil pública paulista, que deu entrada no dia 19 de novembro de 1999, o promotor argumenta que os alunos de escola pública são excluídos do sistema superior de ensino por não terem condições de competir com os das escolas particulares e também de pagar as mensalidades da IES privadas, o que contraria princípio da Carta Magna no qual o Estado deveria garantir o acesso aos níveis mais elevado do ensino, da pesquisa e da criação artística. (Junqueira, 20 nov. 1999 , p. A-13)

A juíza Maria Fernanda de Toledo Rodovalho Podval julgou improcedente o pedido do Ministério Público, alegando que a obrigação do Estado restringe-se 
ao oferecimento do Ensino Fundamental e que a reserva fere a autonomia administrativa das universidades. Entretanto ela também abriu uma brecha:

[...] a única possibilidade de liminar seria aquela que se garantisse o número de vagas na proporção do número de alunos das escolas públicas. Por exemplo: se do total de candidatos, $20 \%$ são ex-alunos da rede pública, apenas um quinto das vagas poderá a eles ser destinada com exlusividade. (FSP, 1999, p. C-3)

Com base nesse trecho da sentença, a EDUCAFRO realizou um levantamento dos candidatos provenientes de escola pública em cada uma das carreiras da USP, encaminhou o estudo ao Ministério Público, pedindo que entrasse com recurso para garantir que a porcentagem final de alunos fosse semelhante à inicial. Novamente o pedido foi negado, agora por um desembargador, com base nos argumentos de autonomia da universidade e acesso ao Ensino Superior segundo a capacidade de cada um.

Além do projeto nacional, em várias Assembléias Estaduais foram apresentadas políticas de cotas para alunos da rede pública. No Estado do Rio de Janeiro as cotas foram aprovadas para as instituições mantidas pelo governo fluminense em dezembro de 2000. A lei aprovada prevê ainda que os alunos sejam assistidos com bolsas-trabalho e adequação curricular. Entidades representativas de escolas privadas cariocas e a Associação de Pais e Alunos do Estado do Rio de Janeiro já se preparam para entrar com ação direta de inconstitucionalidade contra a reserva. Em Santa Catarina, projeto semelhante foi vetado pela Assembléia local e, em São Paulo, o projeto apresentado pelo deputado estadual Celso Tanaui ainda aguarda apreciação da Câmara de Educação. (Ferreira \& Charão, 8 dez. 2000, p. A-14. Mayrink, 17 dez. 2000, p. A-22)

A discussão em torno da adoção da reserva está mais restrita aos poderes legislativo e judiciário, mas, como vimos no caso paulista, foi um dos cursinhos alternativos que motivou o Ministério Público a entrar com ação visando garantir a política de discriminação positiva. 


\subsection{Bolsas em instituições particulares}

Enquanto o estudante carente permanece distante das cadeiras públicas, uma outra forma de garantir seu acesso e permanência é a concessão de bolsas em instituições privadas. Dentre os cursinhos, apenas a EDUCAFRO procurou essa solução para seus alunos.

Nos anos de 1998 e 1999, após a aprovação do aluno, o diretor-geral da EDUCAFRO estabelecia contato com a universidade para a obtenção de bolsas. A forma de concessão era variada: bolsas parciais, totais, a fundo perdido, com ressarcimento previsto no término dos estudos e até, em alguns casos, implicando trabalho gratuito na instituição educacional.

$\mathrm{O}$ fato de o pedido ter sido realizado por um sacerdote e estar vinculado a trabalhos voluntários que o aluno deveria realizar junto aos cursinhos foi sem dúvida um elemento facilitador para a obtenção da bolsa, mas não garantia de sucesso. No caso do requerimento ser dirigido às universidades confessionais, a abordagem era mais tranqüila pela proximidade religiosa existente.

Nos informativos da EDUCAFRO é possível observar o trabalho de garimpagem das diversas bolsas, com resultados obtidos nas seguintes universidades e cursos superiores: Pontifícia Universidade Católica de São Paulo, Universidade São Luís, Universidade São Camilo, Universidade São Francisco, Universidade Mogi das Cruzes, Universidade Santa Cecília, Universidade Claretianas, Universidade Santo Amaro e ESAN.

Para a matrícula em 2001 negociou-se a concessão de bolsas antecipadamente com diversas universidades, as 120 conseguidas foram distribuídas através de um "vestibular da cidadania", no qual o estudante deveria versar sobre temas como ética, discriminação racial, direitos do consumidor, globalização, dentre outros. Parte da avaliação dizia respeito ao auxílio prestado na organização do cursinho e à participação em manifestações organizadas, como, por exemplo, pela isenção das taxas do ENEM ou da FUVEST. O aluno, além de ser aprovado nesse 'vestibular' e na seleção da universidade, tem de se 
comprometer a prestar serviços comunitários sob o risco de ser desligado do projeto, tendo sua bolsa repassada a outro estudante.

A EDUCAFRO, observando a dificuldade de matrícula em uma carreira concorrida como Medicina, foi procurar no exterior uma solução. Foram conseguidas algumas bolsas de estudo em Cuba, estando lá, atualmente, dois alunos.

\subsection{Reivindicações sobre a questão do negro na USP}

As manifestações pelo acesso do negro acentuaram-se com a comemoração dos trezentos anos da morte de Zumbi dos Palmares ocorrida na USP $^{14}$, quando o Núcleo de Consciência Negra passou a pressionar a universidade para adotar cotas para negros. Além de passeatas na porta da FUVEST, várias pichações nos muros da universidade foram realizadas, chamando a atenção para o problema.

Montou-se uma comissão pró-cotas que realizou um projeto para a USP prevendo a reserva de $10 \%$ das vagas para a comunidade afrodescendente por vinte e cinco anos, com uma avaliação da experiência ao final do período. Nunca se conseguiu realizar uma discussão nos órgãos colegiados da universidade sobre o assunto.

Os defensores da ação afirmativa, que chegaram a estampar sua manifestação nos muros acadêmicos, foram ameaçados de expulsão pelo então reitor Flávio Fava de Moraes; a USP chegou a mover ação por lesão ao patrimônio público. Fernando Conceição lembrou, em artigo na Folha de $S$. Paulo, que várias organizações, como sindicatos e o DCE, sempre realizaram pichações, porém nunca haviam sofrido retaliações semelhantes. (Conceição, 1997)

\footnotetext{
14 Nessa comemoração, o intercâmbio entre as experiências dos diversos pré-vestibulares voltados para a população negra facilitou o surgimento de novos cursinhos, como foi o caso do Centro de Estudos Comunitários Paulo Freire.
} 
Os cursinhos do movimento negro, que proliferaram a partir de 1996, continuaram a pressionar a USP pela adoção de cotas através de reuniões com a FUVEST. O resultado foi a criação - através da portaria do Gabinete do Reitor n ${ }^{\circ} .3156$, de 29 de abril de 1999 - da Comissão Permanente de Políticas Públicas para a População Negra junto à reitoria. Dentre suas competências está a de “estimular o ingresso e a permanência dos negros nos quadros discentes da USP”.

O Núcleo de Consciência Negra ainda reivindicou uma cadeira nesta comissão composta apenas por docentes, alegando ser a "entidade que legitimamente representa os negros na universidade". Para tanto, criou um Bloco Pró-Cotas que desfilou em 24 de junho de 1999, caminhando da sede do núcleo até a porta da reitoria.

O principal impacto da comissão, até o momento, foi a inserção no questionário da FUVEST de 2000 do item “cor”, o que melhorou sensivelmente a qualidade da informação a respeito da população afrodescendente existente na USP. Porém a medida não esteve livre de reclamações, já que a FUVEST optou por usar a classificação do IBGE, que incluía como cor a "preta" e a "parda", termos usualmente não aceitos pelo movimento negro, que normalmente adota classificações como afrodescendente, afrobrasileiro e negro.

O levantamento realizado junto aos candidatos e ingressantes para o ano 2000 questionou os dados utilizados pelo movimento negro. Nos panfletos do próprio Núcleo de Consciência Negra encontra-se a afirmação de que apenas 1\% da população de estudantes de graduação da USP seria de negros; na estatística final do exame teve-se 1,3\% que declaram ter cor "preta" e 5,3\% de "pardos",15 entre os ingressantes. (NAEG, 2001b. NCN, jun. 1999)

A inclusão dessa pergunta também permite outras análises; uma delas é observar o número de carreiras em que nenhum ingressante tenha declarado ser de cor preta; no vestibular de 2001 isso aconteceu em 36 das 68 carreiras.

\footnotetext{
${ }^{15}$ Há que se ressaltar que o grupo "pardo" pode incluir a miscigenação do branco com o índio, além de outras combinações que incluem a cor preta.
} 
A pressão pela adoção de cotas também pode ser percebida em artigo no jornal da própria USP. Nele, Petrônio Domingues, coordenador do NCN, conclama aquela universidade a encabeçar o projeto. Para ele seriam quatro os motivos principais que deveriam levar os simpatizantes do anti-racismo a defender essa política:

Primeiro, a campanha pelas cotas coloca na ordem do dia a discussão sobre o racismo no Brasil, quebrando a lei do silêncio que há sobre o assunto; segundo, a simples avaliação de qualquer projeto de cotas por algumas instituição do Estado serve como prova e reconhecimento do racismo; então, o projeto de cotas em si denuncia o racismo como fator de exclusão do negro; terceiro, a política compensatória de cotas representa o resgate de uma dívida histórica que o Estado brasileiro tem com todo afro-brasileiro; quarto, as cotas significariam uma integração, ainda que parcial, do negro à sociedade. (Domingues, 23 a 29 ago. 1999, p.6)

Assim, o NCN vem ao longo dos anos pressionando a USP de diversas formas para que ela dê maior atenção à questão do negro em seus bancos escolares, trabalhando pela inclusão dessa população.

\subsection{Resultados das reivindicações dos cursinhos}

Pôde-se perceber que algumas das pressões exercidas pelos prévestibulares acabaram resultando em mudanças nos exames. Talvez o caso mais visível seja a isenção de taxas de inscrição.

Em outros, não se obtiveram resultados tão concretos, mas o simples fato de discussões sobre reserva de vagas e de qualidade do ensino entrarem em pauta, gerando debates nos meios de comunicação, já constitui um efeito dessa pressão.

Os cursinhos alternativos acabam tendo o papel de porta-voz daqueles que em grande número se formam no Ensino Médio e desejam ingressar no superior; são eles que através da luta pela reserva de vagas e pela inclusão do mais pobre na universidade pública acabam liderando a pressão pela expansão do Ensino 
Superior e participando da elaboração de políticas públicas de acesso para esse estudante.

\section{Considerações finais - Perspectivas de políticas públicas de acesso ao Ensino Superior e a participação dos cursinhos alternativos.}

Durante a década de 1990, a matrícula no Ensino Médio mais que dobrou e estendeu as oportunidades educacionais para uma parcela da população antes excluída; apesar disso, ainda são verificadas desigualdades no acesso, mas os que agora obtêm esse certificado passam a aspirar o nível subseqüente.

Tal como nas décadas de 1960 e 1970, esse incremento da demanda pelo grau universitário gera inúmeras conseqüências, como alterações nos processos seletivos e maior liberdade para a expansão do ensino superior particular. Além disso, outras novidades surgem, como o Exame Nacional de Cursos e um programa de crédito educativo com características de empréstimo.

É no bojo de uma maior aspiração pelo diploma superior que surgem e se multiplicam os cursinhos alternativos voltados para essa população desprovida de recursos financeiros para bancar os custos dos cursinhos comerciais. Como se viu, o crescimento desse tipo de atividade ocorre no mesmo período em que essa nova população começa a obter o certificado de nível médio.

Com o objetivo da inclusão de um público de menor renda na universidade pública, a atuação desses cursinhos não se restringiu ao oferecimento dos estudos preparatórios, incluiu também a criação e a defesa de propostas de políticas públicas que garantam a igualdade e favoreçam o ingresso de seus alunos. Todavia, não há consenso, mesmo entre eles, sobre como atingir tais objetivos. 
Sônia Draibbe (1990) coloca que as políticas públicas podem oscilar entre dois pólos: um seria o da garantia da igualdade de oportunidades, o outro, da procura da igualdade de resultados. A igualdade de oportunidades teria como ênfase a garantia dos mínimos necessários para cada cidadão. A partir disso, mecanismos como o mérito e a regulação pelo mercado seriam definidores do padrão de cada um, com respeito às suas diferenças de habilidade e capacidade. A igualdade de resultados, por sua vez, trataria da distribuição de recursos, produtos e serviços de forma igualitária. Várias alternativas de política se abrem nesse parâmetro, como impostos progressivos e a garantia de alguns serviços a todos os cidadãos, independente de suas características.

Essas distinções na compreensão do que deve ser igualdade, e como alcançá-la, estão no cerne das questões discutidas no acesso ao Ensino Superior. Caso se adote a classificação utilizada por Draibbe, o modelo de seleção calcado na igualdade de oportunidades já existiria: o Estado oferece a educação básica necessária para o ingresso no curso superior; o exame vestibular seria o avaliador do mérito individual para que cada um ocupe o lugar correspondente à sua capacidade e esforço.

Podem ser também consideradas como políticas pertencentes ao campo da igualdade de oportunidades as propostas de isenção de taxas e cursinhos prévestibulares voltados para o atendimento de populações com determinados perfis. Essas podem ser entendidas como ações afirmativas, já que tratam de forma diferenciada essa população.

Já a reserva de vaga, uma outra política de ação afirmativa, seria pertencente ao campo da igualdade de resultados, pois interfere diretamente na seleção realizada, alterando o público ingressante.

A discussão e implementação de cada política pública pela igualdade segue caminho distinto, e a intervenção dos cursinhos alternativos para sua efetivação também pode ser observada de maneira diferenciada. Isso fica bem evidente nos casos de isenção de taxa do vestibular e do ENEM. 


\subsection{Isenção de taxas e redução de custos nos exames seletivos}

A taxa cobrada nos variados exames vestibulares parece constituir um empecilho para os vestibulandos com carência financeira. Com um número crescente desses alunos formando-se no Ensino Médio, é de se esperar que a reivindicação por exames gratuitos ou a preços populares acentue-se no decorrer dos anos.

No caso do ENEM, verificou-se a pressão da sociedade pela gratuidade, inicialmente através do Ministério Público e, após o primeiro resultado favorável, por meio dos cursinhos, que procuraram ampliar o direito a todos os alunos da rede pública. O governo federal assumiu o ônus para os alunos da rede pública, mas repassa parte do custo para os oriundos do ensino privado.

A gratuidade dificilmente se aplicaria aos exames das universidades públicas, já que seu minguado orçamento não permitiria a incorporação deste gasto e, no caso da FUVEST, a taxa do exame é a única fonte de renda da instituição.

Uma solução cogitada foi a da unificação dos exames para as universidades públicas paulistas. Os benefícios seriam imensos: fila única para isenção, diminuição da 'maratona' do vestibulando (com menor número de provas), redução de custos com menor número de técnicos envolvidos na elaboração de questões, fiscais de prova, aluguel de salas, dentre outros.

O professor de física da UFRJ Luís Felipe Coelho, em artigo no Jornal do Brasil, acredita que a unificação dos vestibulares não ocorre devido aos milhões de reais envolvidos na realização de cada exame, dinheiro que se reverte em renda para inúmeras pessoas. (Coelho, 15 nov. 2001)

Vale lembrar que a unificação é uma proposta antiga, que remete à antiga CONVESU, mas que não seguiu adiante. A existência de diversos exames vestibulares trouxe maior variedade no processo avaliativo, o que talvez se perca no caso de um grande e único exame. Cada universidade que desenvolveu seu próprio modelo seletivo reserva críticas aos demais, sendo mais um obstáculo a ser transposto. 
Outras sugestões também apareceram para a redução dos custos. A coordenadora de um cursinho defendeu que a fiscalização de provas fosse realizada através da convocação de alunos das próprias universidades, tal como um mesário de eleição; este seria um trabalho obrigatório e não remunerado. Essa alternativa poderia enfrentar resistência dos universitários, problemas de ausência e de confiabilidade na fiscalização.

Se o preço dos vestibulares já foi um problema no passado devido à inflação, isso retorna, com a incorporação de vestibulandos com menor poder aquisitivo. Como no caso da reserva de vagas, a solução pode se dar através de legislação, contrariando os interesses das universidades. A gratuidade do ENEM, com a sua utilização em larga escala nos exames seletivos, talvez indique para o fim da primeira fase dos grandes vestibulares - em especial o das IFES, que são mais sujeitas às influências das políticas governamentais, ficando as instituições de ensino responsáveis apenas por um segundo estágio da seleção.

A experiência recente aponta que alguns alunos contemplados com a isenção têm conseguido a matrícula na Universidade de São Paulo e na UNESP, mas pôde-se observar que ela por si só não garante a igualdade no processo seletivo.

4.2 A reserva de vaga na universidade pública para estudantes oriundos do ensino público.

Uma solução importada no combate à desigualdade no acesso à universidade é a criação de cotas para populações com determinados perfis desfavorecidos no processo seletivo; a reserva para alunos da rede pública garante uma porcentagem mínima considerada razoável para esta categoria, que é maioria no Ensino Médio.

Com o objetivo de matricular esses estudantes na universidade pública, não foi difícil os cursinhos abraçarem a idéia lançada pelo senador Antero Paes de Barros (PSDB-MT). Como se verificou, alguns patrocinaram ações judiciais pela implementação da reserva. 
O projeto proporcionaria uma alteração importante no perfil do estudante da universidade pública, mas a quantidade de beneficiados seria pequena, pois poucas são as vagas diante da demanda existente.

A reserva, se adotada, terá efeito mais contundente nos cursos que são predominantemente ocupados por estudantes provenientes da rede particular; justamente os mais elitizados, que possuem as notas de corte mais altas e uma grande quantidade de candidatos por vaga. Alguns desses cursos, por terem atendido uma população mais bem preparada durante anos, terão de promover readaptações, curriculares ou na didática de seus professores, para trabalhar com a diversidade dos alunos. Mas o beneficiado pela reserva pode também estar apto para cursar a universidade, afinal o vestibular seleciona de acordo com o número de vagas existentes. Não se pode deduzir que o candidato reprovado não possua as condições mínimas de cursar a universidade, e mesmo este novo aluno passará por um árduo processo seletivo.

A reserva de vagas, caso aprovada, pode gerar um efeito inesperado. Como uma das principais críticas às IES públicas reside no perfil do aluno que lá estuda, e esse é um forte argumento pelo fim da gratuidade, é possível que com a inclusão de um público de menor renda o atual modelo ganhe uma sobrevida, já que isso abafaria uma das principais críticas a ele.

Considerando que há diversidade entre os alunos e os estabelecimentos da rede pública, é de se esperar que os beneficiados sejam alunos de melhor nível social, "apesar" de terem lá estudado. A medida, assim, apenas atenua e não resolve a questão da desigualdade no acesso.

Os alunos que eventualmente se classificariam, mas que perderam essa possibilidade devido às cotas, talvez reajam judicialmente, podendo alguns até conseguir sua matrícula na universidade, o que geraria um fenômeno semelhante ao ocorrido na década de 1960 com os excedentes, que impulsionou a expansão do ensino universitário. A disputa pelas poucas vagas existentes só será aliviada com a expansão e a acomodação de uma maior contingente de estudantes nas universidades públicas. 
Esta mesma disputa poderá se verificar no caso da aprovação de cotas para negros.

\subsection{Em busca da igualdade da população afrodescendente no Ensino Superior:} cursinhos e cotas.

A pressão pela igualdade do negro no acesso ao Ensino Superior não é apenas interna. Na Conferência das Nações Unidas contra o Racismo ocorrida em Durban, na África do Sul, em setembro de 2001, o Brasil foi acusado de racismo por ter no Ensino Superior uma parcela matriculada de afrodescendentes proporcionalmente inferior à existente na população. O governo brasileiro levou a proposta de criação de cotas de ingresso para essa população como uma solução para o problema, mas o Ministro da Educação Paulo Renato de Souza, contrário à reserva de vagas e inspirado nos cursinhos alternativos voltados para essa população, passou a defender subsídios à experiência, indo, para tanto, buscar nove milhões de dólares junto ao Banco Interamericano de Desenvolvimento. (Folha Online, 08 mar. 2002)

O dinheiro seria repassado aos próprios cursinhos existentes, às universidades que os patrocinassem, a estudos sobre políticas de inclusão, à capacitação de professores, a projetos de acesso ao Ensino Superior e à divulgação do programa. O subsídio do governo é o reconhecimento da importância do cursinho como fator de sucesso no ingresso, e também do trabalho realizado por aqueles que adotam um corte racial em sua seleção. Podese dizer que essa experiência contribuiu para o delineamento de novas políticas públicas na área.

Já a reserva de vagas para negros não se restringe à questão do acesso ao Ensino Superior; os concursos para empregos públicos federais também adotaram essa política em algumas áreas no ano de 2002.

A desigualdade acaba por atingir o negro não apenas na educação; pode-se dizer, inclusive, que a participação do Movimento Negro na questão do acesso ao Ensino Superior se dá através de cursinhos como os do Núcleo de Consciência 
Negra, EDUCAFRO e Thema em São Paulo; o PVNC no Rio de Janeiro; e o Steve Biko na Bahia. Esses pré-vestibulares seriam reflexos de discussões mais amplas sobre a condição do negro no Brasil, mas representantes legítimos dessa população no caso do acesso ao Ensino Superior.

No caso paulistano, as propostas de cotas no vestibular parecem distantes de serem concretizadas, embora já tenham ocorrido alguns avanços por conta da pressão dos cursinhos pré-vestibulares que se preocupam com a igualdade racial - como a instalação de uma comissão específica sobre o assunto na USP, resultando na inserção de um item que aborda o aspecto racial no questionário sócio-econômico da FUVEST, e a produção de alguns estudos sobre o tema.

Caso a reserva nos concursos públicos federais se efetive, é provável que se acirre a disputa para a implementação desta política em outras áreas, como o Ensino Superior, através de ações judiciais e outras manifestações reivindicatórias. Talvez a imposição das cotas para a população negra seja externa à vontade das universidades públicas paulistas e da Assembléia Legislativa, e ocorra por lei federal.

Um problema específico na implantação será a determinação de quem é ou não negro. Quando são considerados os dados populacionais do IBGE na definição da porcentagem a ser reservada, é natural que se assuma o mesmo critério utilizado pela fundação - o da autoclassificação - na seleção do Ensino Superior. Isso pode acarretar questionamentos sobre as características pessoais dos beneficiados, e o descrédito desta política.

As propostas existentes estão restritas ao setor público. Embora nele se concentre a educação de melhor qualidade, caso se queira realmente promover a igualdade educacional do negro de forma generalizada, será necessária a ampliação desta política também para o setor privado, que detém maior número de vagas e cresce numa taxa superior. Talvez o Fies tenha de guardar um determinado número de bolsas de estudo voltadas somente para essa população.

Analisando as duas propostas para reduzir a desigualdade, cursinhos e cotas, pode-se perceber que a primeira potencializa o estudante afrodescendente 
para enfrentar o exame, mas não é garantia de sucesso; já a segunda atua diretamente sobre o resultado do exame, sendo em tese mais efetiva.

A adoção dessas políticas pode amenizar a desigualdade no acesso, mas de forma nenhuma atenderá aos anseios daqueles que se inscreveram no vestibular e não conseguiram a matrícula; talvez ela apenas acentue a necessidade de expansão.

\subsection{A crescente demanda pelo Ensino Superior}

Se o objetivo é a inclusão em massa no Ensino Superior das camadas menos favorecidas, são as IES particulares, com maior número de vagas, que oferecem essa possibilidade.

$\mathrm{O}$ atendimento dependeria de políticas que amenizassem o custo para o aluno, com o incremento de programas de crédito educativo, bolsas de estudo e isenção de tributos. Cabe ressaltar que, caso não sejam bem planejados e fiscalizados, podem servir apenas para aumentar os lucros dos empresários do ensino, como já ocorreu no passado. Como foi observado, o governo Fernando Henrique Cardoso, com o programa Fies e a concessão de isenções às IES sem finalidades lucrativas, optou por esse caminho.

Já a expansão do ensino superior público, nos moldes em que este se encontra estruturado, dependeria de grandes investimentos, o que só se concretizaria com mudanças nas prioridades governamentais. A alternativa adotada pelo ministro Paulo Renato de Souza passa pela reestruturação dos cursos de graduação, da atividade do professor - com diminuição do tempo de pesquisa em prol das atividades em sala de aula - e da própria universidade pública.

A pressão de instituições organizadas pelo acesso ao ensino superior público não advém apenas dos cursinhos alternativos. Constatou-se a presença de outras, como a protagonizada pelo Movimento dos Sem Universidade, pelos deputados estaduais e o Ministério Público. 


\subsection{O papel dos cursinhos alternativos}

Os cursinhos alternativos mostraram-se unidos em algumas reivindicações pela igualdade no acesso, mas também mostraram diversidade organizacional e de propostas políticas.

Vários cursinhos adotaram disciplinas que abordam conteúdos inexistentes nos vestibulares. A iniciativa nasceu no Steve Biko da Bahia; outros cursos do Movimento Negro adotaram essa mesma estratégia, e alguns, como o Caehusp e o XI de Agosto, diversificaram essa experiência.

Essas disciplinas têm por objetivo a conscientização dos estudantes, podendo ser sobre questões presentes na sociedade, sobre os direitos humanos, sobre sua condição de vida e os fatores que a determinam; mas também trazem elementos para a ampliação do horizonte cultural do aluno, como a apresentação de filmes, idas ao teatro; ou mesmo procuram desenvolver no aluno sua autonomia e meios para que possa participar mais ativamente da sociedade.

Diferentemente do oferecimento de atividades como orientação vocacional ou da apresentação de um filme sobre um tema abordado no exame vestibular, a adoção dessas disciplinas transcende o objetivo de inclusão no Ensino Superior e passa a formar o aluno para outras finalidades.

No caso dos cursinhos que possuem coordenadores preocupados com a questão do negro no Ensino Superior, a disciplina extra assume um papel bem claro, que é o da disseminação de um conteúdo anti-racista e de reivindicação dos direitos dessa população - sejam culturais, políticos ou educacionais. Isso não quer dizer que haja um consenso entre estes coordenadores sobre a adoção de determinadas políticas públicas de inclusão, como a reserva de vagas.

As discussões realizadas nessas disciplinas possuem papel-chave em alguns cursinhos, principalmente naqueles menos estruturados, com aulas restritas aos sábados, professores voluntários e estudantes portadores de um perfil que desfavorece o ingresso. Nesse caso, elas podem auxiliar o aluno a se conscientizar de suas dificuldades e a visualizar meios, como o protesto, para conseguir sua matrícula, já que o sucesso no vestibular parece estar distante. 
Pode-se dizer que esses cursinhos, ao mobilizar seus alunos - aqueles com perfil desfavorecido no ingresso - pela modificação dos sistemas seletivos, atuam como porta-vozes de uma população mais ampla, que deseja a formação universitária; eles evidenciam a necessidade de modificação no acesso, o aumento da demanda e as transformações que serão necessárias no nível superior para incorporar um novo contingente de pessoas.

A expansão do Ensino Superior torna-se uma questão premente na sociedade brasileira na entrada do novo milênio; talvez por isso os cursinhos alternativos tenham recolhido apoio das mais diversas organizações, como escolas particulares, sindicatos, universidades e empresas.

Ainda existe grande potencial para a expansão do Ensino Médio, indicando que a reivindicação por títulos de graduação pode se intensificar, abrindo possibilidade para outros estudos que acompanhem tanto a luta desses alunos por sua inclusão como mudanças nas políticas governamentais destinadas a suprir essa demanda.

Este trabalho constata como os cursinhos pré-vestibulares alternativos existentes no Município de São Paulo atuaram como um dos agentes na luta pelo Ensino Superior para a população de baixa renda, baseados no princípio da igualdade. Algumas transformações nos sistemas de acesso ocorreram, enquanto outras, sugeridas, foram amplamente debatidas nos meios de comunicação e através de ações judiciais. Assim, tal como em outros trabalhos sobre a expansão do ensino em diversos níveis, neste verifica-se que esta não se deu apenas pela compreensão das necessidades dessa população por parte dos governantes, mas foi fruto de pressões populares ocorridas de diversas formas. 


\section{REFERÊNCIAS BIBLIOGRÁFICAS}

Amaral, N. C. Crise no financiamento das instituições federais de ensino superior. In: Trindade, H. (Org.). Universidade em ruínas: na república dos professores. Petrópolis: Vozes, 1999. p.191-200

Banco Mundial. Pioridades y estrategias para la educación: examen del Banco Mundial. Washington: Banco Mundial, 1996. El dessarollo em la practica.

Barros, Antero Paes. Projeto de Lei 298/99. Senado Federal.

Beisiegel, Celso de Rui. Considerações a propósito de um projeto educacional. São Paulo em Perspectiva. São Paulo, v. 7, n. 1, p.38-49, janeiro/março 1993, Fundação Seade.

Beisiegel, Celso de Rui. Ação política e expansão da rede escolar - os interesses eleitorais do deputado estadual e a democratização do ensino secundário no Estado de São Paulo. Pesquisa e planejamento. São Paulo, nº 8, p.99-198, dezembro de 1964. Revista do Centro Regional de Pesquisas Educacionais "Prof. Queiroz Filho".

Beisiegel, Celso de Rui. Uma política de vestibulares para a Universidade de São Paulo (USP). Estudos em avaliação educacional. São Paulo, n. 11, p.9-14, jan-jun 1995, Fundação Carlos Chagas.

Beisiegel, Celso de Rui. Educação e sociedade no Brasil após 1930. In: Fausto, Boris. História geral da civilização brasileira, Tomo III - O Brasil republicano, $4^{\circ}$ volume - Economia e Cultura, p.381:416. São Paulo: Difel, 1986.

Bobbio, N.; Mateucci, N. \& Pasquino, G. Dicionário de política. Brasília: Ed. Universidade de Brasília, 1986.

Bourdieu, Pierre \& Passeron, Jean-Claude. A reprodução: elementos para uma teoria do sistema de ensino. Rio de Janeiro: Francisco Alves, 1975.

Brandão, Zaia. O processo de seletividade social e o vestibular. In: Brasil/ MEC. Seminários vestibular hoje: coletânea de textos. Brasília, p.165-175, setembro 1987.

Carazzai, Emílio. FIES - Financiamento estudantil - Relatório de gestão 2000. Brasília: Caixa Econômica Federal, 2001. Superintendência Nacional de Distribuição de Serviços ao Cidadão. Disponível em http://www.mec.gov.br/ sesu/ftp/fies/relatgestao/FIES2000.pdf [29 ago. 2001]

Carvalho, Maria Vitória Teixeira de. O Sapiens - Sistema de Avaliação para Ingresso no Ensino Superior. In: Simpósio nacional sobre avaliação educacional: uma reflexão crítica. Anais. Rio de Janeiro: Fundação CESGRANRIO, 1993.

Carvalho, Marília Pinto de. Um olhar de gênero sobre as políticas educacionais. In: Faria, Nalu et alli. Gênero e educação. São Paulo: SOF, 1999, p.9:23. (Coleção Cadernos Sempreviva).

Castro, Célia Lúcia Monteiro. Caracterização sócio-econômica do estudante universitário. Pesquisas e monografias, Rio de Janeiro: Publicação do Centro Brasileiro de Pesquisas Educacionais, MEC, INEP, 1968. Série VIII, vol. 3.

Corbucci, Paulo. O Ensino Superior brasileiro na década de 90. Boletim de políticas sociais: acompanhamento e análise. Brasília: IPEA/ Diretoria de Estudos 
Socais. $n^{\circ} .2$, p.98-109. http://www.ipea.gov.br/pub/bps/bps\%202.pdf [29 de agosto de 2001]

Cunha, Luiz Antônio. A gratuidade do ensino superior público: da proibição à garantia constitucional. In: Velloso, Jacques (Org.). Universidade pública: política, desempenho, perspectivas. Campinas: Papirus, 1991.

Cunha, Luiz Antônio. A universidade crítica: o Ensino Superior na República Populista. Rio de Janeiro: Francisco Alves, 1989.

Cunha, Luiz Antônio. A universidade reformanda: o golpe de 1964 e a modernização do Ensino Superior. Rio de Janeiro: Francisco Alves, 1988.

Cunha, Luiz Antônio. O público e o privado na educação superior brasileira: fronteira em movimento? In: Trindade, H. (Org.). Universidade em ruínas: na república dos professores. Petrópolis: Vozes, 1999. p.39:56.

Dias Sobrinho, José. Concepções de universidade e de avaliação institucional. In: Trindade, H. (Org.). Universidade em ruínas: na república dos professores. Petrópolis: Vozes, 1999. p.149-169.

Dias, José A. e Martelli, Anita F. Caracterização dos candidatos ao vestibular. Estudos e documentos. São Paulo: Faculdade de Educação da USP, 1978. vol.14.

Donosco R., Graciela. Educação Superior no Chile: sistema de admissão às universidades vinculadas ao conselho de reitores. In: Seminário internacional sobre avaliação do Ensino Médio e acesso ao Ensino Superior. Brasília: MEC/INEP, 1998. p.91:98.

Draibbe, Sônia. As Políticas sociais brasileiras: diagnósticos e perspectivas. In: Prioridades e perspectivas de políticas públicas para a década de 90. Brasília: IPLAN/IPEA, mar. 1990, p.1:66.

Durham, Eunice Ribeiro. A política para o Ensino Superior brasileiro ante o desafio do novo século. In: Catani, A. M. (Org.). Novas perspectivas nas políticas de Educação Superior na América Latina no limiar do século XXI. Campinas: Autores Associados, 1998. p.9-28. (Coleção Educação Contemporânea).

Esquivel Larrondo, J. E. Financiamento de la Educación Superior en Chile. In: Campos, R. C., Morán D. P. (Coord.). Políticas de financiamento a la Educación Superior en México. San Ángel: Centro de Estudios sobre la Universidad, UNAM, 1995.

Euriat, Michel. A experiência francesa. Seminário internacional sobre avaliação do Ensino Médio e acesso ao Ensino Superior. Brasília: INEP, 1998. p.25:44.

Fergunson, Richard L. Educação pós-secundária e exames de acesso ao curso superior. In: MEC/INEP. Seminário internacional sobre avaliação do Ensino Médio e Acesso ao Ensino Superior. Brasília: INEP, 1998. p.45:53.

Fernandes, Florestan. Universidade brasileira: reforma ou revolução? São Paulo: Ed. Alfa-Omega, 1975.

Fogaça, Azuete. Educação e qualificação profissional nos anos 90: o discurso e o fato. In: Oliveira, D. A. \& Duarte M. R. T. Política e trabalho na escola: administração dos sistemas públicos de educação básica. Belo Horizonte: Autêntica, 1999.

Freitag, Barbara. Escola, estado e sociedade. São Paulo: Moraes, 1980. 
Freitas, Renan Springer de. O oficial e o institucional: os cursinhos no sistema de ensino. Revista Brasileira de Estudos Pedagógicos. 65 (151):552-75 set./dez. 1984.

Furlani, Lúcia M. Teixeira. A claridade da noite: os alunos do ensino superior noturno. São Paulo: Cortez, 1998.

FUVEST. Informe à imprensa $n^{0} 10 / 2000$.

FUVEST. FUVEST 2000 questionário de avaliação sócio-econômica - estatísticas para candidatos inscritos. Disponível em http://www.mail.fuvest.br/ download/vest2000/qecari00.pdf [10 set. 2001]

FUVEST. FUVEST 2000 questionário de avaliação sócio-econômica - estatísticas para candidatos matriculados. Disponível em http://www.mail.fuvest.br/ download/vest2000/qecarm00.pdf [10 set. 2001]

Grinover, Ada Pellegrini. Pró-reitoria de graduação - plano de metas biênio 2000/2001. 29 nov. 1999.

Guimarães, Antônio S.; Silva, Paula. C. e Prandi, Reginaldo. Análise dos dados sobre a composição da população de estudantes inscritos e matriculados, segundo a cor, no vestibular FUVEST - ano 2000. São Paulo, set. 2000. Disponível em http://www.usp.br/politicaspublicas/relatoriofuvest2001.htm [10 set. 2001]

Hamburguer, Ernst Wolfgang. O exame vestibular e os desajustes dos sistemas de ensino. In: Simpósio sobre exames vestibulares. Revista Ciência e Cultura vol. $22 \mathrm{n}^{\circ} .3$ - separata, 1970.

Hamburguer, Ernst Wolfgang. Seletividade social e o vestibular. In: Seminários vestibular hoje: coletânea de textos. Brasília: MEC. setembro 1987. p. 153-159.

IPEA. Acompanhamento de políticas e programas governamentais. Boletim de políticas sociais: acompanhamento e análise. Brasília, $\mathrm{n}^{\circ} .2$, p.13-93. IPEA/ Diretoria de Estudos Socais. http://www.ipea.gov.br/pub/bps/bps\%202.pdf [29 ago. 2001]

Martins, Carlos Benedito. O Ensino Superior no Brasil. In: São Paulo em Perspectiva. São Paulo: Fundação Seade, janeiro/março 1993. v. 7, n. 1, p.50-57.

Martins, Carlos Benedito. Ensino pago: um retrato sem retoques. São Paulo: Cortez, 1988.

Moehlecke, Sabrina. Propostas de Ações Afirmativas no Brasil: o acesso da população negra ao Ensino Superior. Dissertação de Mestrado. São Paulo, FEUSP, 2000.

NAEG. Inscritos e aprovados FUVEST por grupos étnicos. Disponível em http://naeg.prg.usp.br/pesquisas/result_raca.xls. [12 nov. 2001b]

NAEG. Estudo do desempenho dos candidatos da FUVEST/USP segundo o ensino médio realizado. Disponível em http://naeg.prg.usp.br/pesquisas/ ensinoMedio.phtml [12 nov. 2001a]

Oliveira, Carlos Alberto Serpa de. A avaliação técnica ao longo do $2^{\circ}$ grau e o acesso à universidade. In: Seminários vestibular hoje: coletânea de textos. Brasília: MEC, setembro 1987. p.41-51. 
Oliveira, João Ferreira de. Mudanças no CNE e na avaliação do Ensino Superior. In: ANPAE hoje, jul./set. 2001, p.8.

Oliveira, Romualdo Portela. Educação e cidadania: o direito à educação na Constituição de 1988 da República Federativa do Brasil. Tese de Doutorado. Faculdade de Educação da USP, São Paulo, 1995.

Oliveira, Romualdo Portela; Catani, Afrânio Mendes. Constituições estaduais brasileiras e educação. São Paulo: Cortez, 1993.

Peixoto, Maria do Carmo L.; Braga, Mauro Mendes. A demanda por vagas no Ensino Superior: análise dos vestibulares da UFMG na década de 90. Disponível em http://www.anped.org.br/1110t.htm [17 ago. 2001]

Prandi, Reginaldo. Os favoritos degradados: Ensino Superior e profissões de nível universitário no Brasil hoje. São Paulo: Edições Loyola, 1982. (Coleção "EDUC-AÇÃO”).

Ribeiro, Sérgio Costa. A visão de professores e alunos das IES hoje. In: Seminários vestibular hoje: coletânea de textos. Brasília: MEC, setembro 1987. p.29-40.

Sampaio, Helena; Limongi, Fernando \& Torres, Haroldo. Eqüidade e heterogeneidade no Ensino Superior brasileiro. Brasília: INEP, 2000.

Santos, Maria Durvalina Cerqueira. Educação cidadania e reconstrução de identidades: caso Cooperativa Steve Biko. Dissertação de Mestrado. Salvador, UFBA, 1997.

Schwartzman, Simon. O Ensino Superior no Brasil - 1998. Série documental. Brasília: MEC/INEP, 1999. n. 6. Textos para discussão.

Setton, Maria da Graça Jacintho. A divisão interna do campo universitário: uma tentativa de classificação. Revista Avaliação, 1998.

Souza, Paulo Renato. Conferência inaugural. São Paulo: CONSED, 1998. Coletânea Seminário Internacional Políticas Públicas do Ensino Médio.

Souza, Paulo Renato. Universidades federais: ensino de qualidade para mais alunos. In: Resultados e tendências da Educação Superior no Brasil. Brasília: MEC/INEP, 2000. Disponível em www.inep.gov.br/censosuperior [20 set. 2000]

Spósito, Marilia Pontes et alli. O trabalhador-estudante: um perfil do aluno do curso superior noturno. São Paulo: Loyola, 1989.

Spósito, Marilia Pontes. Algumas hipóteses sobre as relações entre movimentos sociais, juventude e educação. [CD-ROM] 22 Reunião Anual da ANPED - Associação Nacional de Pós-Graduação e Pesquisa em Educação. 1999.

Spósito, Marília Pontes. O povo vai à escola: a luta popular pela expansão do ensino público em São Paulo. São Paulo: Loyola, 1984. (Coleção Educação Popular).

Teixeira, Anísio. Uma perspectiva da educação superior no Brasil. Depoimento prestado à CPI da Educação Superior da Câmara dos Deputados, 8 mai. 1968. In: Teixeira, A. Educação e universidade. Rio de Janeiro: Ed. UFRJ, 1988. Reúne a produção científica de Anísio Teixeira publicada em periódicos.

UFSM. PEIES - Programa de Ingresso ao Ensino Superior. Disponível em http://www.ufsm.br/coperves/peies.htm [15 mar. 2002] 
UnB. O que é o Programa de Avaliação Seriada. Disponível em http://www.cespe.unb.br/pas/index.htm [10 jan. 2002]

USP/IEA A presença da universidade pública. São Paulo, USP, janeiro de 2000. Comissão de Defesa da Universidade Pública instituída junto ao Instituto de Estudos Avançados da Universidade de São Paulo.

Vianna, Heraldo Marelim. Acesso à universidade - análise de alguns modelos alternativos de seleção. In: Seminários vestibular hoje: coletânea de textos. Brasília: MEC, setembro 1987. p.131-140.

Vianna, Heraldo M. Acesso à universidade - os caminhos da perplexidade. Educação e Seleção. São Paulo: Fundação Carlos Chagas, n 14, jul-dez 1986. p.87:132, .

Vieira, Sofia Lerche. Universidade federal nos anos 80: o jogo da política educacional. Tese de Doutorado. São Paulo, PUC-SP, 1990.

VUNESP. Relatório vestibular UNESP 2001. Fundação para o Vestibular da Universidade Estadual Paulista, São Paulo, 2001a.

VUNESP. Relatório vestibular UNESP 2001 - suplemento: programa de formação de professores e outras forma de isenção. Fundação para o Vestibular da Universidade Estadual Paulista, São Paulo, 2001b.

Whitaker, Dulce C. A. A seleção dos privilegiados: um estudo sobre a educação brasileira. São Paulo: Semente, 1981. (Coleção Revelações).

Whitaker, Dulce C. A. UNESP: diferentes perfis de candidatos para diferentes cursos (Estudos de variáveis formadoras do capital cultural). Fundação para o Vestibular da Universidade Estadual Paulista - VUNESP, 1989.

Whitaker, Dulce C. A. e Fiamengue, Elis C. Dez anos depois: UNESP: diferentes perfis de candidatos para diferentes cursos (Estudo de variáveis de capital cultural). Fundação para o Vestibular da Universidade Estadual Paulista VUNESP, 1999.

Artigos de jornais e revistas

Aceituno, Jair. Professor propõe taxa única de $\mathrm{R} \$ 20,00$ por aluno para vestibular. $\mathbf{O}$ Estado de S. Paulo. 11 set. 1999, p.A-10.

Alves, Rubem. O fim dos vestibulares. Folha de S. Paulo. 6 fev. 1995, p1-3. Opinião.

Amaral, Marina. Cursinho para pobres. Revista Caros Amigos $n^{0} .35$, fev. 2000, p.1315.

Athias, Gabriela. ENEM poderá ser referência para contratações. O Estado de S. Paulo. 30 ago. 1999, p. A-9.

Avancini, Marta. Carentes prestam vestibular da cidadania. O Estado de S. Paulo. 16 nov. 2000, p. A-23.

Avancini, Marta. Na FUVEST, exame não mudaria muito a lista dos aprovados. O Estado de S. Paulo. Entrevista com Roberto Costa, 27 ago. 2000, p.A-18.

Bacchetto, João G. Da evasão à transferência. Jornal da USP. 15 a 21 nov. 1999, p.2. 
Bresser Pereira, Luiz Carlos. A sagrada missão pública. Folha de S. Paulo. p. 10:11, 4 jun. 2000. Caderno Mais - Universidade em choque.

Brianezi, Thaís. Falta de verbas poderá fechar cursinho do NCN. Jornal do Campus. 7 a 20 out. 1999, p.3.

Cafardo, Renata. FUVEST pode suspender isenção de inscrição. O Estado de S. Paulo. 11 jan. 2001, p. A-14.

Cafardo, Renata. Alunos se dizem lesados por fundação da USP. O Estado de S. Paulo. 29 ago. 2001, p.A-12.

Coelho, Luis Felipe. Desigualdade e crise universitária. Jornal do Brasil. 15 nov. 2001. In: Clipping Educacional, 15 nov. 2001, CONSAE.

Conceição, Fernando. Zimbábue forever. Folha de S. Paulo. 16 jun. 1997, p. 3-2.

Domingues, Petrônio José. Em defesa das cotas para afro-brasileiros na USP. Jornal da USP. 23 a 29 ago. 1999, p. 6.

ENEM isenta carentes em 2001. Folha de S. Paulo. 27 jul. 2000, p. C-4.

Escóssia, Fernanda Da. Regulamentação de lei sobre cotas gera polêmica sobre definição de cor. Folha de S. Paulo. 14 nov. 2001.

Estudantes fazem até pedágio para tentar o vestibular. O Estado de S. Paulo. 27 dez. 2000, p. A-7.

Estudantes querem processar governos. Folha de S. Paulo. 3 dez. 2000, p.C-4.

Felinto, Marilene. Donos de universidade monopolizam vagas. Folha de S. Paulo. 19 dez. 2000, p. C2.

Ferreira, Adriana e Charão, Cristina. UERJ discorda das cotas mas acata decisão. O Estado de S. Paulo. 8 dez. 2000, p. A-14.

Floresta, Cleide. Para aluno bolsa é excludente. Folha de S. Paulo. 9 out. 1999, p.3-5.

MEC e BID assinam acordo que beneficia alunos carentes. Folha Online. http://www.uol.com.br/folha/educacao/ult305u8380.shtml [08/03/2002]

FUVEST solta lista de candidatos isentos de taxa. Folha de S. Paulo. 11 set. 2001, p.C4.

Gois, Antônio. USP abre 1.500 vagas para transferência. Folha de S. Paulo. 18 fev. 2000, p.7.

Junqueira, Juliana. Promotor quer reserva de vaga na USP. O Estado de S. Paulo. 20 nov. 1999, p. A-13.

Junqueira, Juliana. USP, UNESP e UNICAMP podem unificar vestibular. O Estado de S. Paulo. 26 out. 1999, p. A-13.

Lahóz, André. Universidade deve ser paga, diz Nobel. (entrevista com Gary Becker) Folha de S. Paulo. 5 maio 1996, p. 1-13.

Leite, R. C. C. Maquiavel e a universidade pública. Folha de S. Paulo. 13 dez. 1999, p3. Tendências/ Debates. Opinião.

Liminar garante isenção no Rio. Folha de S. Paulo. 20 jun.2000, p. C-6.

Liminar manda CEF refazer cálculo do crédito educativo. Folha de S. Paulo. 5 fev. 2000, p.3-4. 
Macedo, Lino de. Vestibular 2000 - Lei de Gerson? Jornal da USP. S14 a 20 jun. 1999, USP, p.2. Opinião.

Mayrink, José Maria. Reserva de vagas desagrada a gregos e troianos. O Estado de $\mathbf{S}$. Paulo. 17 dez. 2000, p. A-22.

Nascimento, Carla. Com raça para passar. Revista Isto É. $1^{0}$ jul. 1998, p.59. Educação.

Neubauer, R. Pelo fim do paternalismo. Folha de S. Paulo, 31 jan. 2000, p.3. Tendências / Debates. Opinião.

Pereira, Luiz Carlos Bresser. A sagrada missão pública. Folha de S. Paulo. 4 jun. 2000, p10-11. Caderno Mais!

Picanço, Marcy. Isenções não resolvem carência. Jornal do Campus. 19 ago. a 2 set. 1999, p.8.

'Queremos causar indignação', diz frade. Folha de S. Paulo. 27 ago. 2000, p.C-11.

Reserva de vagas na USP é negada. Folha de S. Paulo. 23 nov. 1999, p.C-3.

Rossetti, Fernando. Crédito educativo deve R\$ 159 mi a escolas. Folha de S. Paulo. São Paulo, 04 dez. 1997, p.3-4.

Silva, Alessandro; Floresta, Cleide. Governo nega crédito a 18 mil carentes. Folha de $\mathbf{S}$. Paulo. 9 out. 1999, p3-5.

Sistema anterior não permitia poupança durante o curso. Folha de S. Paulo. 15 nov. 1999, p.2-5.

Soares, Guido Fernando Silva. O ENEM e a USP. Jornal da USP. 24 a 30 maio 1999, USP, p.2. Opinião.

Valente, José Luiz. Vantagens do novo modelo. Folha de S. Paulo. 12 jun. 1999, p.1-3. Tendência e Debates.

Weber, Demétrio. Ensino pago pode estar nos planos do MEC. O Estado de S. Paulo. 25 ago. 1998 , pA-9.

Weber, Demétrio. Paulo Renato quer ENEM em vez de vestibular. O Estado de S. Paulo. 9 ago. 2000, p. A-21.

Weber, Demétrio. Rede particular tem melhor resultado no ENEM. O Estado de S. Paulo. 14 dez. 2000, p.A-13.

Publicações dos cursinhos

AEUSP, Associação dos Educadores da USP. Disponível em http://www.geocities.com/athens/column/8849/ [10/05/2001]

AFROBRAS, 111 anos da abolição da escravatura - sem educação não há liberdade. Folder, s/ data.

APROVE. APROVE e seus objetivos. I Encontro Experiências de Pré-Vestibulares Populares - UFSC, Florianópolis, 4 a 6 maio 2000.

CAEHUSP. Revista do CAEHUSP, março de 1996.

CAEHUSP. Manual do candidato. 1999. 
CAEHUSP. Chega de excursão! Cartaz, s/ data.

CAEHUSP. Festa de lançamento do cursinho pré-vestibular. Panfleto, s/ data.

CAVC. Manual do candidato - intensivo. 2000.

Centro Comunitário e Estudos Paulo Freire. Ficha do candidato. 1999(?).

Cursinho da Poli promovendo a inclusão social. O politécnico. ago. 2001.

Cursinho da Poli. Manual do candidato. nov. 1999.

Cursinho do XI de Agosto. Estágio na área de educação. Cartaz para recrutamento de professores, 1999(?).

Educafro. O que são pré-vestibulares comunitários, 1999(?). (mimeo)

Educafro. Parecer jurídico - Processo contra o Estado de São Paulo - péssima qualidade de ensino. São Paulo, nov./dez. 2000.

IAPSI. Projeto cursinho Psico-USP, I Encontro Experiências de Pré-Vestibulares Populares - UFSC, Florianópolis, 4 a 6 maio 2000.

IAPSI. Manual do candidato. 2000.

IAPSI. Fórum dos cursinhos alternativos e comunitários do Estado de São Paulo. Disponível em http://cpsico.hypermart.net/ [22 set. 2001]

IAPSI. Desempenho dos alunos nos exames de instituições públicas de ensino superior. Disponível em http://cpsico.hypermart.net/ [22 set. 2001]

Movimento Humanista. Cursinho pré-vestibular gratuito: três novos cursinhos humanistas atendem estudantes menos favorecidos. In: Abertura. Jornal do Clube Humanista de Cidadania da USP. Nov. 1998, $\mathrm{n}^{\circ} .10$ ano 3.

Movimento Humanista. Atenção voluntários!!! Cartaz utilizado para recrutamento de professores. (s/data)

Movimento Humanista. Questionário do aluno. (s/data)

Núcleo de Consciência Negra. Ato público em defesa de cotas para a população negra na USP. Panfleto. jun. 1999 (?).

Núcleo de Consciência Negra. Jornal quilombos. abr. 1999.

THEMA. Manual do candidato. 2000 (?)

\section{Documentos oficiais}

Brasil. Constituição da República Federativa do Brasil. Editora Saraiva, $24^{a}$ edição, 2000. (Coleção Saraiva de Legislação).

Brasil. Lei de Diretrizes e Bases da Educação no 9.394 de 20 de dezembro de 1996. (mimeo)

Brasil. Lei de Diretrizes e Bases da Educação nº 4.024 de 20 de dezembro de 1961. (mimeo)

Brasil. Lei da Reforma do Ensino no 5.692 de 11 de agosto de 1971. (mimeo) 
Brasil. Lei $n^{\circ} 9.131$ de 24 de novembro de 1995. Altera dispositivos da Lei $n^{\circ} 4.024$, de 20 de dezembro de 1961, e dá outras providências. In: Brasília: PRASEM II Marcos Legais.

IBGE. Anuário Estatístico do Brasil 1968. Fundação IBGE, Brasília, 1970.

IBGE. Anuário Estatístico do Brasil 1978. Fundação IBGE, Brasília, 1979.

IBGE. Anuário Estatístico do Brasil 1989. Fundação IBGE, Brasília, 1989.

IBGE. Pesquisa Nacional por Amostragem Domiciliar - 1998. Fundação IBGE, 1999.

IBGE. Pesquisa Nacional por Amostragem Domiciliar - 2001. Fundação IBGE, 2002.

MEC/INEP. Censo Escolar 1998. Disponível em http://www.inep.gov.br/dowload/ censo/1998/basica/ SINOPSE_1998.zip [10 nov. 2000]

MEC/INEP. Censo Escolar 1999. Disponível em http://www.inep.gov.br/dowload/ censo/1999/basica/ SINOPSE_1999.zip [18 out. 2001]

MEC/INEP. Censo Escolar 2000. Disponível em http://www.inep.gov.br/dowload/ censo/2000/basica/ sinopse2000.zip [18 out. 2001]

MEC/INEP. Censo Escolar 2001. Disponível em http://www.inep.gov.br/dowload/ censo/2001/basica/ sinopse2001.zip [10 mar. 2002]

MEC/INEP. Evolução do Ensino Superior 1988-1998. Disponível em www.inep.gov.br/censosuperior [20 set. 2000]

MEC/INEP. Sinopse Estatística do Ensino Superior 2001. Disponível em www.inep.gov.br/censosuperior [10 out. 2002]

MEC/INEP. Documento Básico do ENEM - 1999.

Pará. Agenda compromisso com a educação pública no Estado do Pará. Secretaria de Estado da Educação do Pará, 1995(?). (mimeo) 


\section{ANEXO 1}

Questionário sócio-econômico por dependência administrativa do Exame Nacional de Cursos

Resposta à questão: Em qual das faixas abaixo você calcula estar a soma da renda mensal dos membros da sua família que moram em sua casa?
A - Até $\mathrm{R} \$ 453,00$.
B - De R $\$ 454,00$ a R $\$ 1.510 .00$.
$\mathrm{C}$ - De R $\$ 1.511,00$ a R $\$ 3.020,00$.
$\mathrm{D}$ - De R $\$ 3.021,00$ a R $\$ 7.550,00$.
$\mathrm{E}$ - Mais de R\$7.550,00.

Formandos em Administração por dependência administrativa e faixa de renda

\begin{tabular}{|l|r|r|r|r|r|r|}
\hline & $\mathbf{A}$ & $\mathbf{B}$ & $\mathbf{C}$ & $\mathbf{D}$ & $\mathbf{E}$ & $\mathbf{N}$ \\
\hline Estadual & 8.38 & 40.63 & 28.9 & 16.27 & 5.6 & 0.2 \\
\hline Federal & 6.4 & 32.27 & 31.88 & 22.63 & 6.63 & 0.15 \\
\hline Municipal & 3.9 & 36.43 & 36.3 & 17.93 & 5.07 & 0.33 \\
\hline Privada & 2.73 & 26.72 & 34.43 & 24.61 & 11.04 & 0.43 \\
\hline
\end{tabular}

Fonte: http://www.inep.gov.br/enc/resultados/questionario

Formandos em Medicina por dependência administrativa e faixa de renda

\begin{tabular}{|r|r|r|r|r|r|r|}
\hline & $\mathbf{A}$ & $\mathbf{B}$ & $\mathbf{C}$ & $\mathbf{D}$ & $\mathbf{E}$ & $\mathbf{N}$ \\
\hline Estadual & 2.32 & 17.9 & 30.49 & 32.72 & 15.77 & 0.77 \\
\hline Federal & 5.16 & 21.88 & 30.69 & 28.37 & 12.97 & 0.9 \\
\hline Municipal & 1.45 & 11.62 & 24.41 & 38.95 & 22.09 & 1.45 \\
\hline Privada & 1.79 & 14.38 & 27.95 & 34.09 & 20.94 & 0.82 \\
\hline
\end{tabular}

Fonte: http://www.inep.gov.br/enc/resultados/questionario

Formandos em Direito por dependência administrativa e faixa de renda

\begin{tabular}{|r|r|r|r|r|r|r|}
\hline & $\mathbf{A}$ & $\mathbf{B}$ & $\mathbf{C}$ & $\mathbf{D}$ & $\mathbf{E}$ & $\mathbf{N}$ \\
\hline Estadual & 4.43 & 27.05 & 27.97 & 26.89 & 11.85 & 1.78 \\
\hline Federal & 5.33 & 24.54 & 30.51 & 28.78 & 9.71 & 1.09 \\
\hline Municipal & 3.65 & 27.41 & 32.86 & 25.6 & 9.01 & 1.44 \\
\hline Privada & 3.23 & 24.88 & 32.47 & 26.68 & 11.16 & 1.55 \\
\hline
\end{tabular}

Fonte: http://www.inep.gov.br/enc/resultados/questionario 


\section{ANEXO 2}

Mapeamento das atividades e da constituição dos cursinhos prévestibulares alternativos do Município de São Paulo

\section{Dados gerais}

1. História do surgimento do cursinho e sua motivação inicial (projeto político).

2. Data da fundação.

3. Entidade a qual está vinculado.

4. Possui estatuto próprio, registrado em algum cartório?

5. Onde este se situa?

\section{Dados financeiros}

1. Recebe verbas de quais entidades?

2. Há taxa de matrículas iniciais?

3. Há mensalidades ou contribuições?

4. Há uma perspectiva de valores anuais arrecadados pelo cursinho?

5. Quais as principais despesas?

\section{Professores}

1. Qual o vínculo dos professores? Eles são registrados?

2. Há remuneração?

3. Existe uma formação requerida para ministrar as disciplinas?

4. Há alguma instrução pedagógica específica?

5. Qual a forma de recrutamento?

6. Qual a motivação destes para se associar aos cursinhos?

\section{Proposta pedagógica}

1. Existe algum material que é exigido do aluno?

2. É distribuído algum tipo de apostila?

3. Além das aulas, são realizadas outras atividades com os discentes? Qual o grau de aceitação ou participação?

4. Há alguma orientação na escolha de carreira dos alunos?

\section{$\underline{\text { Alunos }}$}

1. Quantos candidatos procuram esta instituição?

2. Qual o critério de seleção?

3. Possui quantos alunos atualmente?

4. Este número é variável?

5. Há um perfil sócio-econômico destes?

6. Quais os índices de aprovação dos alunos nas principais universidades? 